\title{
THE ANTITRUST ANALYSIS OF HOSPITAL MERGERS AND THE TRANSFORMATION OF THE HOSPITAL INDUSTRY
}

\author{
JONATHAN B. BAKER*
}

\section{INTRODUCTION}

Hospital mergers, once rare in the United States, have grown commonplace in the current decade. During the early 1980's, acquisitions or consolidations occurred at the rate of roughly two hundred per year, dramatically higher than the yearly rates of fifty in 1972 and five in 1961.1 Although no more than 3 percent of all U.S. hospitals are involved in such transactions each year, ${ }^{2}$ many, if not most, urban areas have already seen a hospital merger or consolidation. ${ }^{3}$

The growing frequency of hospital mergers is but one aspect of a much broader structural transformation of the U.S. hospital industry in the 1980's. New institutions have become part of the fabric of health care, and thus of the environment in which hospitals operate. Formerly peripheral institutions have grown in significance. These new or growing institutions include free standing surgical and ambulatory outpatient clinics, health maintenance organizations ("HMO's") and preferred provider organizations ("PPO's"),

Copyright (C) 1989 by Law and Contemporary Problems

* Assistant Professor, The Amos Tuck School of Business Administration, Dartmouth College, Hanover, N.H. The author is indebted to many people for helpful discussions including Terry Calvani, Michael Fischer, and Joseph Simons; John Sipple on Hart-Scott-Rodino reporting; Toby Singer on antitrust exemptions and FTC jurisdiction; William Blumenthal on cluster markets; Robert G. Hansen and Steven Salop on product complementarity; and especially Monica Noether and Frank Sloan for close readings of an earlier draft. The opinions expressed in this article are not necessarily those of these colleagues

1. Finkler \& Horowitz, Merger and Consolidation: An Overview of Activity in Health Care Organizations, 39 HealthCaRe Fin. MGmT., Jan. 1985, at 19.

2. The United States had 6,872 hospitals in 1984. U.S. Dep't of Commerce, Statistical Abstract of the U.S. 1987, at 94 [hereinafter 1987 Statistical Abstract].

The merger rate is similar when expressed in terms of hospital beds. The early 1980's acquisitions encompassed roughly 20,000 beds per year. Finkler \& Horowitz, supra note 1 , at 25 . See generally Mullner \& Andersen, A Descriptive and Financial Ratio Analysis of Merged and Consolidated Hospitals: United States, 1980-1985, 7 advances in Health Economics and Health Services RESEARCH 41 (1987). Roughly $1,360,000$ beds were available in the U.S. hospital industry in the early 1980's, 1987 Statistical ABStract, supra, at 94, so nearly $1.5 \%$ of hospital beds were involved in such transactions each year.

3. In the first three months of 1986, significant combinations occurred or were discussed in the San Francisco, Rochester, Minnesota, Chicago, Baltimore, and Brookline, Massachusetts areas. Mullner \& Andersen, supra note 2, at 41-42. 
for-profit hospitals, multi-hospital systems, and hospital management contracts. ${ }^{4}$ Furthermore, the direct regulatory supervision of hospitals has changed in the past two decades. In virtually all states, hospital capital investments require a certificate of need ("CON") from a state regulatory body, or else a CON requirement has recently been abolished. ${ }^{5}$ Third party reimbursement for hospital expenses has shifted from a cost-based system to a prospective payment system ("PPS"), primarily for patients with Medicare but also for other patients in some states. ${ }^{6}$

Another important regulatory change is indirect. The application of antitrust law to the health field differs in the 1980's from the patterns characteristic of earlier decades. Today, unlike past decades, it is generally understood that most activities of the health professions and hospitals are governed by the antitrust laws. Hospital mergers are now reviewed under the same antitrust framework as applies to any acquisition. ${ }^{7}$ Furthermore, antitrust law of the 1980's differs markedly from the antitrust law of the 1960 's, including differences in its merger analysis.

Because antitrust law, the hospital industry structure, and the regulatory framework applied to hospital activities have each changed dramatically from their appearance in previous decades, the present antitrust constraints on hospital mergers may seem novel to hospitals, lawyers, and courts. This article shows how the antitrust analysis of hospital mergers depends upon the features of the regulatory scheme applied to the hospital industry, both directly and through the influence of regulation on industry structure and conduct. It concludes that for the provision of many hospital services, demand substitutes are limited, supply substitutes also may be limited, geographic markets are often no larger than a single metropolitan area, entry is time consuming, and market concentration is high. Under the current antitrust law and enforcement policy, these structural characteristics of the hospital industry will call for close scrutiny of hospital mergers.

\section{II}

The Regulation of Health Care Provision: Response to Market Failure

The antitrust analysis of hospital mergers depends importantly upon certain features of the health care regulatory scheme. Moreover, recent changes in the regulatory environment may be responsible for the rise in hospital industry acquisitions in the early 1980's. Important aspects of the regulatory framework and its historical evolution will be outlined below.

4. See infra notes $32-34,137,207$ and accompanying text.

5. See infra notes $16 \cdot 17,22-23,292-97$ and accompanying text.

6. See infra notes $20-21,24$ and accompanying text.

7. The Federal Trade Commission has taken a leadership role in showing how antitrust law applies to hospital mergers. See American Medical Int'l, 104 F.T.C. 1 (1984); Hospital Corp. of Am., 106 F.T.C. 361 (1985), aff'd, 807 F.2d 1381 (7th Cir. 1986), cert. denied, 481 U.S. 1038 (1987). In this area, the FTC is ably exploiting its unique ability as a specialized antitrust court to shape the law where it was once unclear. 
Most people are risk-averse and are uncertain about the nature, cost, and timing of future health care requirements. Prepaid health insurance, the obvious market response, is therefore extremely desirable. ${ }^{8}$ In its most common historical forms, however, the insurance mechanism reduces the elasticity of the demand for health care. Once health care is paid for entirely or in large part, consumers have little incentive to economize on cost. ${ }^{9}$ Furthermore, insurance schemes have historically incorporated retrospective cost-based or charge-based reimbursement for health care providers, giving hospitals little incentive to minimize costs or compete on price. ${ }^{10}$ As a result, prepaid health insurance has led to the overprovision of health care and to high health care prices. ${ }^{11}$

The bias created by prepaid health insurance toward inefficiently high health care prices and usage is further exacerbated by information problems associated with the health care market. Patients often have little knowledge about their illnesses and how to treat them. Doctors act as agents for patients, in many cases deciding on the amount of care and the hospital at which it will be provided, and often simultaneously supplying that care. When physician compensation is tied to the level of care and doctors are patient agents in selecting the care level, the price and quantity of medical care will tend to rise to inefficiently high levels. ${ }^{12}$

8. See generally Crandall, The Impossibility of Finding a Mechanism to Ration Health Care Resources Efficiently, in A New Approach to the Economics of Health Care 29 (M. Olson ed. 1981); Joskow, Alternative Regulatory Mechanisms for Controlling Hospital Cosis, in A NEW Approach to The Economics of Health CARe, supra, at 219, 220-26; Hospital Corp. of Am., 106 F.T.C. at 457-58.

Health markets with prepaid health insurance are not free of other forms of market failure, however. The necessary insurance contracts may be too complex, and insurance raises well-known adverse selection and moral hazard difficulties. See generally Crandall, supra, at 31,34 (complex contracts); Pauly, Overinsurance and Public Provision of Insurance: The Roles of Moral Hazard and Adverse Selection, 88 Q.J. Econ. 44 (1974).

9. From $80 \%$ to $90 \%$ of the U.S. population has fairly extensive hospital insurance coverage, and the typical insured patient pays about $5 \%$ of hospital charges incurred. P. Joskow, ControllinG Hospital Costs 11 (1981). To the extent insurance schemes have large deductibles and no copayments, patients likely pay less than $5 \%$ of marginal hospital charges.

10. See generally id. at 27-31; $c$. Danzon, Hospilal "Profits": The Effects of Reimbursement Policies, $1 \mathrm{~J}$. Health ECON. 29 (1982) (hospitals have an incentive to maximize the difference between reimbursable accounting costs and true economic costs for insured patients, creating a bias toward high patient charges for insured patients).

11. Many schemes have been proposed for preserving the consumer's benefits of prepaid health insurance while reducing the systemic tendency for inefficiently high prices and output of the health care sector. See generally Pauly, Overinsurance: The Conceptual Issues, in National Health Insurance: What Now, What Later, What Never? 201 (M. Pauly ed. 1980); Crandall, supra note 8, at 34; Zeckhauser \& Zook, Failures to Control Health Costs: Departures from First Principles, in A New APPROACH to THE ECONomics of Health Care, supra note 8, at 87, 109-10 (effects of cost-based reimbursement); $c f$. Introduction to A NEw Approach to THE Economics of Health Care, supra note 8 , at 1, 24-25 (vertical integration among insurers and hospitals would give hospitals an incentive to minimize costs and patients an incentive to prefer less costly hospitals). Despite the bias toward overprovision of health care in the economy as a whole, the distribution of access to health care is uneven: Poor and rural consumers may be underprovided with health care. See id. at 7.

12. This incentive is present even assuming that all physicians act ethically in making decisions for the provision of care. For a discussion of the agency relationship between doctor and patient, and the possibility that physicians induce a demand for medical care, see, for example, M. PAuLy, Doctors and Their Workshops: Economic Models of Physician Behavior (1980). 
The regulatory scheme put into place in the United States in the 1960's exacerbated these biases in favor of high health care prices and high levels of health care provision. Medicare and Medicaid, landmark federal insurance programs for the elderly and poor enacted in 1965, relied upon retrospective cost-based reimbursement of health care providers, physicians, and hospitals. ${ }^{13}$ Not surprisingly, a health care explosion occurred. Health care prices continued to rise at a substantially higher rate than prices generally, ${ }^{14}$ and the health care share of the Gross National Product increased from 4.4 percent in 1950 and 5.3 percent in 1960 to 7.4 percent in 1970 and 9.1 percent in 1980.15

Congress addressed these skyrocketing health care costs in the 1970's and early 1980's when it enacted the main elements of the regulatory scheme shaping the provision of health care today. In 1974, Congress placed limitations on the quantity of health care provided consumers in order to control the health care explosion. Large hospital capital expenditures became subject to the supervision of state regulatory boards, through the requirement for a CON. ${ }^{16}$ Virtually all states enacted CON programs by 1979 , while only five had required CON approvals before 1970.17 Furthermore, applying a

13. Social Security Amendments of 1965, Pub. L. No. 89-97, sec. 102(a), § 1814 (b), sec. 121 (a), $\S 1905$ (a), 79 Stat. 286, 296, 351 (codified as amended at 42 U.S.C. $\$ \S 1395 f(b), 1396$ (d) (1982)) Under cost reimbursement, the only marginal costs borne by patients, and thus the only source of limits on their health care purchases, come from the opportunity cost of obtaining care, including costs of time away from work or leisure and costs of travel.

14. Even before the creation of the Medicare and Medicaid programs in the 1960's, health care prices were increasing more rapidly than the prices of most other goods and services. From 1953 to 1962, the Consumer Price Index ("CPI") for medical care rose $36.0 \%$, while the aggregate CPI rose $13.1 \%$. Since that time, above average health care inflation rates have continued. From 1963 to 1972 , the medical CPI rose by $54.8 \%$ while the aggregate CPI rose by $36.6 \%$. From 1973 to 1981 , when the CPI for energy rose by $232.0 \%$, the medical CPI increase of $113.9 \%$ continued to outpace the aggregate CPI increase of $104.7 \%$. From 1982 to 1986 , the medical CPI rose by $31.9 \%$ while the aggregate CPI rose by only $13.6 \%$. During this time, the aggregate CPI was likely aided more than the medical CPI by the decline of $11.0 \%$ in the energy CPI. See EConomic RePort of THE PRESIDENT 307 (1987).

15. 1987 Statistical Abstract, supra note 2, at 84 (figures for 1970 and 1980); U.S. Dep't of Commerce, Statistical Abstract of the U.S. 1984, at 102 (figures for 1950 and 1960). The health care share of Gross National Product has continued to rise, reaching $10.7 \%$ in 1985.1987 Statistical Abstract, supra note 2, at 84. Some of these price increases may reflect improvements in the quality and scope of services provided. P. Joskow, supra note 9, at 15.

16. National Health Planning \& Resources Development Act of 1974, Pub. L. No. 93-641, sec. 3, $\S 1523(\mathrm{a})(4), 88$ Stat. 2225, 2246 (1975) (codified at 42 U.S.C. $\$ 300 \mathrm{~m}-2$ (1982) (repealed 1986)). The typical CON board reviewed all expenditures above $\$ 100,000$ to $\$ 150,000$. Joskow, supra note 8 , at 219,234 . Similar review of capital expenditures was encouraged by $\S 1122$ of the Social Security Act. Social Security Amendments of 1972, Pub. L. No. 92-603, sec. 221, § 1122, 86 Stat. 1329, 1386 (codified as amended at 42 U.S.C. $\S 1320 a-1$ (1982 \& Supp. 1988)). See generally Frech, The Long-Lost Free Market in Health Care: Government and Professional Regulation of Medicine, in A NEw APproACH TO THE Economics of Health Care, supra note 8, at 44, 61-66; Joskow, supra note 8, at 219, 234-43; Steinwald \& Sloan, Regulatory Approaches to Hospital Cost Containment: A Synthesis of the Empirical Evidence, in A New Approach to The Economics of Health Care, supra note 8, at 274. Federal Communications Commission regulation of broadcasting provides another example of the use of entry restrictions rather than the price mechanism to ration access to resources. See T. MorGan, J. Harrison \& P. Verkuil, Economic Regulation of Business Cases and Materials 136-37 (2d ed. 1985).

17. P. Joskow, Controlling Hospital Costs 92-93 (1981). However, 21 states enacted CON requirements between 1970 and 1974 , before such programs were federally mandated. 
similar regulatory approach to other aspects of health care provision, Congress required that outside experts monitor and limit physician choice of care through peer review. ${ }^{18}$

Congress's 1974 mechanism for taming the health care explosion, based on monitoring and policing capital expenditures and care decisions, was replaced in the 1980's by a new incentive mechanism to attack high health care prices. Building on the experience of several states with all-payer prospective payment systems, ${ }^{19}$ Congress introduced in 1983 a prospective payment system ("PPS"), ${ }^{20}$ covering a substantial fraction of hospital revenues, $" 1$ to replace cost-based Medicare reimbursement. By 1986, CON's were no longer required, ${ }^{22}$ and in consequence have been abolished by over one quarter of the states. ${ }^{23}$

Under the PPS, Medicare provides for a standardized payment to every hospital nationwide for each patient with a given diagnosis. These payments are based primarily on 1981 average nationwide costs associated with the treatment of the patient's diagnostic related group ("DRG"). ${ }^{24}$ The cap on payments guarantees that each hospital will recover the average costs associated with the typical treatment and experience of patients with each

18. Social Security Act Amendments of 1972, Pub. L. No. 92-603, § 249F, 86 Stat. 1329, 1429 (codified as amended at 42 U.S.C.A. $\$$ 1320c tol320c-13 (West 1983 \& Supp. 1988)) (Professional Standards Review Organizations ("PSRO")). By the end of the 1970's, most areas of the United States had some type of PSRO program in operation. Steinwald \& Sloan, supra note 16, at 282-84.

19. See generally Hellinger, Recent Evidence on Case-Based Systems for Setting Hospital Rates, 22 INQUIRY 78 (1985); but of. Cone \& Dranove, Why Did States Enact Hospital Rate-Setting Laws?, 29 J. L. \& ECoN. 287 (1986) (state rate-setting laws were enacted to correct monitoring problems created by Medicaid law, rather than as a response to increasing medical expenses generally).

20. Social Security Amendments of 1983, Pub. L. No. 98-21, §§601-607, 97 Stat. 65, 149-72 (codified as amended in scattered sections of 42 U.S.C.).

21. See Div. of Nat'l Cost Estimates, Office of the Actuary, Health Care Financinc. Admin., Vational Health Expenditures, 1986-2000, 8 Health Care Financing Rev., Summer 1987, at 1, 30 (Medicare accounts for nearly $30 \%$ of hospital care expenditures).

22. See supra note 16. Most studies conclude that neither CON nor PSRO programs were successful at achieving health care cost reductions. See generally Sloan, Government and the Regulation of Hospital Care, 72 Am. ECon. Rev. 196 (Papers \& Proceedings 1982); Joskow, supra note 8, at 219, 23443; Steinwald \& Sloan, supra note 16, at 274, 285-96; but see Howell, Evaluating the Impact of Certificate. of-Need Regulation L'sing Measures of Liltimate Outcome: Some Cautions from Expenience in Massachusetts, 19 Health Services Res. 587 (1984) (CON success increases over time, as state boards develop experience); Ashby, The Impact of Hospital Regulatory Programs on Per Capila Costs, Litilization, and Capilal Investment, 21 INQUIRY 45 (1984) (CON effect on cost containment is ambiguous, but PSRO's reduced the rate of growth in hospital costs since 1977). Empirical evidence on the entry deterring effects of CON laws is discussed infra note 296.

23. General Accounting Office, Health Care facilities: Capital Construction ExPEnditures by STATE, app. I (1986). In addition, the Department of Health and Human Services no longer undertakes capital reviews pursuant to $\$ 1122$ of the Social Security Act, although that statute has not been repealed. Another Upset for Health Planning, 41 Med. \& Health Persp. (OCt. 5, 1987).

24. See generally Staff of House Comm. on Ways and Means, 100th Cong., 1st Sess., Background Material and Data on Programs Within the Jurisdiction of the Committee on Ways AND MEANS 221-36 (Comm. Princ 4, 1987). The program incorporated a four year phase-in period, during which hospitals were reimbursed a declining percentage of their own historical costs, and during which reimbursement was based in part on regional costs. Future reimbursements will be adjusted for inflation. 
diagnosis, but will not recover more. In consequence, hospitals must cut treatment costs in order to increase profits.

Although it may be too early to evaluate the effect of the Medicare prospective payment system on hospital costs, ${ }^{25}$ the industry appears to have grown more competitive in consequence. The preliminary evidence suggests that both hospital admissions and hospital stays, measures of industry output, have declined as a result of the program ${ }^{26}$ and as a result, hospital occupancy rates have fallen dramatically. ${ }^{27}$ Because it is unlikely that the program

25. See generally Hellinger, supra note 19, at 85. Preliminary evidence suggests that the rate of hospital cost increases declined in 1984 and 1985, following the imposition of the Medicare PPS. See Guterman \& Dobson, Impact of the Medicare Prospective Payment System for Hospitals, 7 Healtr Care FinANCING Rev. 97, 111 (1986) (increase in real Medicare benefit payments for inpatient and outpatient hospital care slowed in 1984); 1987 Statistical ABstract, supra note 2, at 85, Table No. 127 (expenditures on hospital care fell from $41.1 \%$ of total health expenditures in 1983 to $39.2 \%$ in 1985 , and expenditures on medical facilities construction fell from $2.6 \%$ of the total in 1983 to $1.9 \%$ in 1985); id. at 86, Table No. 128, 88, Table No. 134 (rate of growth of per capita health care expenditures and hospital room charges both slowed in 1984 and 1985).

The continued (albeit slowed) growth in Medicare reimbursements despite the cost-cutting pressures of the PPS may reflect hospital manipulation of the PPS program. Hospitals can increase reimbursements through more conservative diagnoses. For example, if colds and pneumonia were diagnostic categories, and the reimbursement level were greater for the latter diagnosis, then hospitals could increase revenues by diagnosing likely colds as possible pneumonia. See Guterman \& Dobson, supra, at 104; but of. Vertrees \& Manton, The Complexity of Chronic Disease at Later Ages: Practical Implications for Prospective Payment and Data Collection, 23 INQUIRY 154 (1986) (constructing DRG's based on five dimensions of diagnosis may limit ability of hospitals to manipulate categories). The continued growth in reimbursements might also reflect increases in the demand for medical care engendered by the growth of medical science and the resulting increase in the quality and variety of health care services offered. Cf. P. Joskow, supra note 9, at 11-19 (dramatic health care quality improvements in the 1970's).

Evidence from states with rate reimbursement schemes antedating the Medicare PPS suggests that the prospective payment approach reduces health care expenses. Morrisey, Conrad, Shortell \& Cook, Hospilal Rate Review: A Theory and An Empirical Review, 3 J. Health Econ. 25, 37-41 (1984); Dranove \& Cone, Do State Rate Setting Regulations Really Lower Hospital Expenses?, 4 J. Health Econ. 159 (1985); M. Noether, Competition Among Hospitals 74 (Bureau of Economics, FTC 1987).

26. Hellinger, supra note 19, at 85; Guterman \& Dobson, supra note 25, at 103-04, 109; but cf. Newhouse \& Byrne, Did Medicare's Prospective Payment System Cause Length of Stay to Fall?, 7 J. Health ECON. 413 (1988) (Medicare led long-term patients to shift from short-term acute care hospitals to other hospitals.). The reduction in hospital admissions may derive from hospital incentives under the Medicare PPS to drop services that they cannot provide more cheaply than average. $C f$. Newhouse, Two Prospective Diffculties with Prospective Payment of Hospitals, or, It's Better to Be a Resident than a Patient with a Complex Problem, 2 J. Health Econ. 269, 272 (1983) (quality of care provided to severely ill patients and profits of teaching hospitals providing tertiary care may suffer from PPS); Sheingold \& Buchberger, Implications of Medicare's Prospective Payment System for the Provision of Cincompensated Hospital Care, 23 INQUIRY 371, 372 (1986) (hospitals with PPS deficits may be forced to provide less uncompensated care).

Although treatment quality declines when patients substitute outpatient, nursing, and home health care for inpatient hospital care, this substitution may reflect a more efficient use of social resources. See generally Ellis \& McGuire, Provider Behavior Under Prospective Reimbursement: Cost Sharing and Supply. $5 \mathrm{~J}$. HeALTh ECON. 129 (1986). However, the PPS program will likely generate inefficiently low innovation in the provision of medical care by hospitals, other than cost-reducing innovation. See Sloan \& Valvona, Prospective Payment for Hospital Capital by Medicare: Issues and Options, 11 HCM Rev. 25, 32 (1986); Lee \& Waldman, The Diffusion of Innovations in Hospitals, 4 J. Health ECoN. 373, 379 (1985).

27. The average annual U.S. hospital occupancy rate for short-term hospitals was between $73 \%$ and $76 \%$ during every year from 1972 to 1983 , but fell to $68.9 \%$ in 1984 . 1987 Statistical Abstract, supra note 2, at 95 . The occupancy rate among for-profit hospitals fell from $65.5 \%$ in 1982 to $57.0 \%$ in 1984 . Id. at 94 . In 1986, 31 states reported $50 \%$ occupancy and 35 states reported $63 \%$ occupancy. Bean, Latest Survey Shows Hospital Charges Increasing Far More Quickly Than CPI, Wall 
increased the costs of providing inpatient care, the best explanation for the reduction in industry output is that the PPS scheme led to a substantial reduction in the demand for hospital care. ${ }^{28}$ This decline in demand could reduce the equilibrium number of hospitals ${ }^{29}$ and increase the intensity of hospital competition, unless the marginal cost reduction induced by hospital response to the Medicare prospective payment system is equally dramatic. Furthermore, price ceilings on insurance reimbursements ${ }^{30}$ will likely push hospitals to substitute price competition for quality competition. ${ }^{31}$

Increased competition among health care providers has led to a variety of changes in industry structure. ${ }^{32}$ The rapid growth of multihospital systems, ${ }^{33}$ whether created through new construction, acquisition, or management

St. J., Jan. 6, 1988, at 17, col. 4. The average number of hospital of beds used per day fell by $9.5 \%$ in 1984 , more than treble the $2.8 \%$ decline in 1983 and the $2.7 \%$ decline in 1982 . In contrast, the average number beds used per day held constant between 1978 and 1981.1987 Statistical. Abstract, supra note 2, at 97.

28. The new reimbursement program caps physician reimbursement in much the same way as it limits hospital revenues. To the extent physicans act as patients' agents in demanding hospital services, and to the extent doctors are able to induce patient demand for medical care, the new reimbursement program gives doctors incentives to reduce the medical care they demand on behalf of their patients, thus reducing hospital admissions rates. Similarly, hospitals can be expected to encourage staff physicians to reduce the hospital services employed per patient, thus reducing the average length of hospital stays.

29. The number of hospitals in the United States fell by 37 between 1982 and 1984. This reduction continued a long-term trend involving the exit of small hospitals from the industry. 1987 Statistical Abstract, supra note 2, at 93, Table No. 147. See generally Mullner, Byre \& Kubal, Hospital Closure in the United States 1976-1980: A Descriptive Overview, 18 Health Services Res. 437 (1983); Kennedy \& Dumas, Hospital Closures and Survivals: An Analysis of Operating Characteristics and Regulatory Mechanisms in Three States, 18 Health Services Res. 489 (1983); Bean, Small Rural Hospitals Siruggle for Survival Under Medicare Setup. Wall St. J., Jan. 4, 1988, at 1, col. 1; cf. Sager, Why Urban Voluntary Hospitals Close, 18 Health Services Res. 451 (1983) (small hospitals serving minority or Medicaid-funded patients are more likely to close). The low rate of hospital closings suggests that the distress sale of assets is unlikely to account for a large fraction of hospital merger statistics.

30. As with the Medicare PPS, Blue Cross and other insurers are similarly moving toward prospective payments, so that ceilings on reimbursement levels may soon apply to most hospital services. See M. Noether, supra note 25, at 87-88.

31. See id. at 84-88; Zwanziger \& Melnick, The Effects of Hospital Competition and the Medicare PPS Program on Hospital Cost Behavior in Califormia, $7 \mathrm{~J}$. Health Econ. 301 (1988); United States v. Rockford Memorial Corp., No. 88-C-20186, slip. op. at 81-84 (N.D. Ill. Feb. 23, 1989) (order granting injunction), appeal filed. In the past, hospitals would compete for patients primarily by offering them (or their doctors) amenities. Hospital Corp. of Am., 106 F.T.C. 361, 478-79 (1985); cf. White, Quality, Competition and Regulation: Evidence from the Airline Industry, in REgulating the Product 17 (R. Caves \& M. Roberts eds. 1975) (quality competition among airlines subject to price regulation); G. Douglas \& J. Miller, Economic Regulation of Domestic air Transport: Theory and Policy (1984) (same).

32. In addition to the structural changes discussed in the text, a growing number of affiliations among hospitals, doctors, and private health insurers may result from cost-cutting pressures. See generally Baker, l'ertical Restraints Among Hospitals, Physicians and Health Insurers that Raise Rivals 'Costs: $A$ Case Siudy of Reazin v. Blue Cross and Blue Shield of Kansas, Inc. and Ocean State Physicians' Health Plans, Inc. v. Blue Cross and Blue Shield of Rhode Island, 14 AM. J. L. \& MED. 147 (1988).

33. In $1985,35 \%$ of U.S. hospitals and $38 \%$ of U.S. community hospital beds were owned, leased, or managed by a multihospital system. Alexander, Lewis \& Morrisey, Acquisition Strategies of Multihospital Systems, 4 Health AfFs., Fall 1985, at 49, 50. Only 24\% of hospitals and 30\% of hospital beds had been incorporated in multihospital systems in 1979. Mullner, Byre \& Kubal, Multihospital Systems in the linited States: A Geographical Overview, 15 Soc. Sci. \& MEd. 353, 353 (1981). The number of hosptial beds incorporated in multihospital systems rose at an annual rate of $3.0 \%$ from 1975 to 1982. Ermann \& Gabel, Multihospital Systems: Issues and Empirical Findings, 3 Heal.th Afrs., Spring 1984 , at 50,52 . From 1970 to 1981 , the number of hospitals under management contract rose from 
contracts, may be a response to cost-cutting pressures derived from recent regulatory changes. ${ }^{34}$ Through this mechanism, the changing regulatory environment may have induced the recent wave of hospital acquisitions requiring antitrust analysis.

\section{III}

\section{The Changing Role of Antitrust Law}

\section{A. The Antitrust Revolution of the 1970's}

As the regulatory framework governing the provision of health care has altered over the last two decades, so too has antitrust law changed. Antitrust of the 1980's is built around a different paradigm from the antitrust law of the 1960 's as a result of the widespread adoption of the Chicago School critique of the earlier approach. Economic efficiency has become the lodestar of antitrust, and the populist goals important in the past are now treated merely as historical curiosities. ${ }^{35}$ In addition to their normative focus on economic efficiency, Chicago School critiques of 1960's antitrust law are characterized by a presumption that most markets work well because entry is easy ${ }^{36}$ and collusion is difficult to coordinate and enforce. In consequence, Chicago

14 to 497 , and the number grew by $20 \%$ from 1979 to 1980 . Alexander \& Lewis, Hospital Contract Management: A Descriptive Profile, 19 Health Services Res. 461, 461 (1984).

34. It is plausible that multihospital systems provide economies relative to free standing facilities. The rapid growth of investor-owned hospital chains has been attributed to scale economies in production, superior management, and lower capital costs, although the capital cost advantage of hospital chains over single hospitals appears small. See generally Sloan, Morrisey \& Valvona, Capital Markets and the Growth of Multihospital Systems, 7 Advances in Health Economics and Health Services Research 83, 84, 103 (1987); Ermann \& Gabel, supra note 33, at 50, 54-58; $c$. Alexander \& Lewis, The Financial Characteristics of Hospitals under For-Profit and Nonprofit Contract-Management, 21 INQUIRY 230, 240 (1984) (increased profits of contract managed hospitals may reflect efficiency in use of plant and total organizational investment). Further, acquired hospitals are likely to obtain a substantial fraction of revenues from Medicare and Medicaid reimbursements; acquired and managed hospitals are likely located in areas where HMO's are growing rapidly; and multihospital systems are unlikely to take on the ownership or management of high labor cost facilities. Morrisey \& Alexander, Hospital Participation in Multihospital Systems, 7 Advances in Health Economics and Health Services Research 59, 75 (1987). These observations are consistent with the view that hospital systems constitute a response to regulator-or insurer-created cost-cutting pressures.

Other studies fail to document economies from multihospital systems. Renn, Schramm, Watt \& Derzon, The Effects of Ownership and System Affliation on the Economic Performance of Hospitals, 22 INQuIRY 219 (1985) (no differences in productive efficiency can be attribuced to system affiliation); Levitz \& Brooke, Independent versus System-Affiliated Hospitals: A Comparative Analysis of Financial Performance, Cost, and Productivity, 20 Health Services Res. 315 (1985) (system hospital profitability results from higher markups, lower capital costs, and superior management, but not from more productive use of plant and equipment). Similarly, one study has found that contract management increases hospital profitability by raising prices rather than improving productive efficiency. Kralewski, Dowd, Pitt \& Biggs, Effects of Contract Management on Hospital Performance, 19 Health Services Res. 479 (1984). Further, some hospital acquisitions appear to be a mechanism for circumventing state certificate-ofneed requirements rather than a way of reducing costs. In some locations, in order to obtain the right to open a new hospital in a suburban market with favorable demographics, a hospital may purchase and close a nearby urban facility with declining occupancy. Alexander, Lewis \& Morrisey, Acquisition Strategies of Multihospital Systems, 4 Health Affs., Fall 1985, at 49, 56.

35. See generally ABA Antitrust Section, Monograph No. 12, Horizontal Mergers: Law and Policy 5-26 (1986) [hereinafter Horizontal. Mergers]; K. Davidson, Megamergers 103-28 (1985).

36. However, Chicago School antitrust practitioners accept that entry may be difficult when the government is the source of the entry barrier. 
School scholars typically offer efficiency explanations rather than anticompetitive explanations for business practices and market concentration, and recommend antitrust enforcement less frequently than was common in the 1960's. ${ }^{37}$

The antitrust revolution of the 1970's is particularly evident in two doctrinal areas. ${ }^{38}$ First, in 1977 the Supreme Court reversed its hostility to vertical restraints imposed by manufacturers on distributors, such as exclusive distribution territories. ${ }^{39}$ The Court accepted the Chicago School position that these practices typically benefit consumers by facilitating interbrand competition among manufacturers. ${ }^{40}$ Second, in the 1970's, the courts of appeals commenced a revolution in product market definition by incorporating supply substitutability into their analysis. Remarkably, the federal appellate courts undertook this initiative with no direction from the Supreme Court. ${ }^{41}$ These courts recognized that firms could not act

37. See, e.g., R. Bork, The Antitrust Paradox: A Policy at War with Itself (1978); R. Posner, Antitrust Law (1976).

38. For a discussion of other aspects of the antitrust revolution, see generally $\mathrm{T}$. Calvani \& $\mathrm{M}$. Sibarium, Antitrust Today: Maturity or Decline (Feb. 21, 1989) (unpublished manuscript); Barnett, Halverson, Scher \& Whiting, Interview with James C. Miller, III, Chairman, Federal Trade Commission, 53 Antitrust L.J. 5, 5-1 1 (1984). The change in perspective has led to the relaxation of doctrines of per se illegality predicated on pre-Chicago economic analyses. See Millstein \& Kessler, The Antitrust Legacy of the Reagan Administration. 33 Antrtrust Bull. 505, 513-14 (1988).

39. Continental T.V., Inc. v. GTE Sylvania, Inc., 433 U.S. 36 (1977) (overruling United States v. Arnold, Schwinn \& Co.. 388 U.S. 365 (1967)).

40. GTE Syluamia, 433 U.S. at 56 (relying on Bork and Posner); but see infra note 45 (vertical practices can reduce economic efficiency).

41. The Supreme Court expressly employed supply substitutability to define a product market in United States v. Columbia Steel Co., 334 U.S. 495, 510-11 (1948). The Court also acknowledged the principle in a footnote in Brown Shoe Co. v. United States, 370 U.S. 294, 325 n.42 (1962) ("The cross elasticity of production facilities may also be an important factor in defining a product market ...") (dictum).

Nevertheless, antitrust product market definition in the Supreme Court has been based almost exclusively on demand substitutability. United States v. E.I. du Pont de Nemours \& Co., 351 U.S. 377, 404 (1956) [hereinafter Cellophane] (defining product market as goods with "reasonable interchangeability" in demand); see, e.g., R. Posner, supra note 37, at 127 (Cellophane formulation of market definition is deficient because it ignores production substitutes). For example, two years after Brown Shoe, the Supreme Court majority ignored production flexibility in defining a product market, despite the district court's finding of extensive supply substitutability. Compare United States v. Aluminum Co. of Am., 377 U.S. 271, $276-77$ (1964) [hereinafter Rome Cable] (insulated copper conductor and insulated aluminum conductor placed in separate markets because of insufficient demand substitutability), with Rome Cable, 377 U.S. at 285 (Stewart, J., dissenting) (district court's broad market definition should be upheld based on both demand and supply substitutability). Further, in a case decided shortly after Rome Cable, the Court claimed to follow the demand substitutability "teaching" of the Cellophane decision although it expressly recognized that the services incorporated in its product market did not statisfy the reasonable interchangeablity test. United States v. Grinnell Corp., 384 U.S. 563, 571-73 (1966) (placing central station burglar alarm and fire alarm services in the same product market). While Grinnell can be understood as incorporating supply substitutability in product market definition, see infra note 159, the Court did not acknowledge this interpretation.

Given the Court's emphasis on demand substitutability, the federal circuits were understandably reluctant to accept supply substitutablity as a basis for product market definition for two decades following the Cellophane decision, even when confronted by the economic logic which later carried the argument. See, e.g., L. G. Balfour Co. v. FTC, 442 F.2d 1, 11 (7th Cir. 1971); Reynolds Metals Co. v. FTC, 309 F.2d 223 (D.C. Cir. 1962) (Burger, J.); Crown Zellerbach Corp. v. FTC, 296 F.2d 800, 812 15 (9th Cir. 1961), cerl. denied, 370 U.S. 937 (1962). 
anticompetitively, successfully raising price above competitive levels, if other firms could readily alter production processes to make a competing product. ${ }^{42}$ More recently, courts have extended the supply substitution principle to incorporate another form of potential competition, entry, into the market power analysis. The new cases recognize that no firm can have market power, regardless of its market share, if prospective competitors can readily enter its market. ${ }^{43}$

The most important emerging critique of Chicago School antitrust doctrines is an economic one, accepting economic efficiency as the goal of antitrust while disagreeing with Chicago School practitioners over the likely economic consequences of various business practices and the plausibility of anticompetitive conduct. ${ }^{44}$ For example, economists writing on topics of antitrust relevance have identified situations in which vertical practices can

42. The leading decisions were issued in separate circuits less than one month apart in 1975 . Telex Corp. v. International Business Mach. Corp., 510 F.2d 894, 914-19 (10th Cir.) (recognizing the Cellophane standard as the law while justifying its result by Grinnell), cert. dismissed, 423 U.S. 802 (1975); Twin City Sportservice, Inc. v. Charles O. Finley \& Co., 512 F.2d 1264, $1271-74$ (9th Cir. 1975) (relying on Columbia Steel and the Brown Shoe footnote, although terming the Cellophane standard the "point of departure" for product market definition), aff'd after remand, 676 F.2d 1291 (9th Cir.), cert. denied, 459 U.S. 1009 (1982). After these decisions, supply substitutability analysis was rapidly incorporated into product market definition by other circuits and the Federal Trade Commission. Yoder Bros., Inc. v. California-Florida Plant Corp., 537 F.2d 1347, 1368 (5th Cir. 1976), cert. denied, 429 U.S. 1094 (1977); United States v. Empire Gas Corp., 537 F.2d 296, 303-04 (8th Cir. 1976), cert. denied, 429 U.S. 1122 (1977); Budd Co., 86 F.T.C. 518, 569-72 (1975); but see Kaiser Aluminum \& Chemical Corp. v. FTC, 652 F.2d 1324, 1330-32 (7th Cir. 1981) (reluctance to incorporate supply substitutability into market definition). Further, the supply substitutability approach was rapidly endorsed in commentary. R. Posner, supra note 37, at 127-28; Note, The Role of Supply Substitutability in Defining the Relevant Product Market, 65 VA. L. Rev. 129 (1979); Note, Potential Production: A Supply Side Approach for Relevant Product Market Definitions, 48 Fordham L. Rev. 1199 (1980); but of. Horizontal Mergers, supra note 35, at 74-75 (collecting cases questioning "whether production flexibility alone is adequate to support a broad market definition").

43. United States v. Waste Management, Inc., 743 F.2d 976 (2d Cir. 1984); United States v. Calmar, Inc., 612 F. Supp. 1298, 1301 , 1305-07 (D.N.J. 1985); Echlin Mfg. Co., 105 F.T.C. 410 (1985); $c$. Antitrust Div., Dep't of Justice, 1984 Merger Guidelines $\$ 3.3,49$ Fed. Reg. 26,823, 26,832 (1984) (Dep't unlikely to challenge mergers in markets in which entry is easy); HorizonTAL Mergers, supra note 35, at 205 (entry not treated as a significant consideration in merger analysis until recently). Entry is often considered at a later stage of merger analysis than supply substitutability, however. See infra note 184 .

44. An alternative strand of recent critical commentary would reemphasize the populist goals important in the 1960's. Lande, The Rise and (Coming) Fall of Efficiency as the Ruler of Antitrust, 33 Antitrust Bull. 429 (1988); Fox \& Sullivan, Antitrust-Retrospective and Prospective: Where are We Coming From? Where Are We Going?, 62 N.Y.U. L. Rev. 936 (1987); Lande, Wealth Transfers as the Original and Primary Concern of Antitrust: The Efficiency Interpretation Challenged, 34 Hastings L.J. 65 (1982) (advocating wealth transfer standard rather than economic efficiency standard as criterion for the application of antitrust rules); see generally HorizonTAl. MERGERS, supra note 35, at 8 n.31, 11 \& n.38 (collecting commentary); K. Davidson, supra note 35, at 380 n.66 (same); cf. Fisher \& Lande, Efficiency Considerations in Merger Enforcement, 71 CALIF. L. Rev. 1580 (1983) (comparing efficiency and wealth transfer standards); Rowe, Antitrust in Transition: A Policy in Search of Itself, 54 Antrtrust L.J. 5, 12-13 (1985) ("[T]he extreme efficiency-based antitrust rollback" is inconsistent with antitrust's role in U.S. history and culture "to balance enterprise and power by controls of competition mediated by law" and to provide to the world "a new ideology to supplant old regimes of statism and cartelization, offering an alternative to the laissez-faire capitalism and state socialism that divided the industrial world for generations."). 
harm economic efficiency through their horizontal effect, ${ }^{45}$ offered a new explanation for predatory pricing and an empirical example of its successful use, ${ }^{46}$ called into question the plausibility of the presumptions that entry is easy and market power rare, ${ }^{47}$ revived the theory that multimarket contact reduces the incentive of conglomerates to compete, ${ }^{48}$ and demonstrated that

45. This new literature on "raising rivals' costs" challenges the Chicago School conclusion that vertical restraints are typically beneficial from within the economic efficiency paradigm. Krattenmaker \& Salop, Anticompetitive Exclusion: Raising Rivals ' Costs to Achieve Power Over Price, 96 YalE L.J. 209, 277-82 (1986); Salop \& Scheffman, Cost-Raising Strategies, 36 J. Indus. Econ. 19 (1987); cf. Salop, Practices that (Credibly) Facilitate Oligopoly Coordination, in NEw Developments in the ANALYSIS OF Market Structure 265 ( J. Stiglitz \& G. Mathewson eds. 1986) (the widespread use of certain vertical arrangements may facilitate horizontal collusion). The possibility that vertical hospital mergers might be anticompetive because they raise rivals' costs is discussed infra notes 136.38 and accompanying text.

A recent legislative initiative to preserve antitrust law's prohibition of resale price maintenance against the challenges of Chicago School commentators is similarly defended by its supporters on economic efficiency grounds. House Comm. on the Judiciary, Report on the Freedom From Vertical Price Fixing Act of 1987, H.R. Rep. No. 421, 100th Cong., 1st Sess. $11-13$ (1987).

46. Saloner, Predation, Mergers, and Incomplete Information, 18 Rand J. Econ. 165 (1987); Burns, Predalory Pricing and the Acquisition Cost of Competitors, $94 \mathrm{~J}$. Pol. Econ. 266 (1986); Milgrom \& Roberts, Predation, Reputation, and Entry Deterrence, 27 J. Econ. Theory 280 (1982); Kreps \& Wilson, Reputation and Imperfect Information, $27 \mathrm{~J}$. ECON. Theory 253 (1982). The Chicago School view that predatory pricing is irrational has recently been accepted by the Supreme Court. Matsushita Elec. Indus. Co. v. Zenith Radio Corp., 475 U.S. 574, 589 (1986) (noting with approval the "consensus among commentators that predatory pricing schemes are rarely tried, and even more rarely successful").

47. See Bresnahan, Empirical Studies of Industries with Market Power, in HandBook of INdustrial Organization (R. Schmalensee \& R. Willig eds.) (forthcoming) (survey of recent empirical analyses demonstrates that a great deal of market power exists in some concentrated industries).

The entry analysis of pioneering industrial organization economist Joe $\mathrm{S}$. Bain is gaining renewed currency as economists are again taking seriously the possibilities that scale economies and advertising can create entry barriers. Compare Salop, Measuring Ease of Entry, 31 ANTITrust Bull. 551, 563-65 (1986) (scale economies may create entry barriers), with Echlin Mfg. Co., 105 F.T.C. 410 , 488-89 (1985) (Chicago School view that scale economies are not entry barriers); compare Salop, Strategic Entry Deterrence, 69 Am. ECoN. Rev. 335 (Papers \& Proceedings 1979) (advertising may create entry barrier), with Telser, Some Aspects of the Economics of Advertising, $41 \mathrm{~J}$. Bus. 166, $169-70$ (1968) (Chicago School view that advertising has procompetitive effects); see generally J. BAIN, BARRIERS TO New Competition (1956).

48. The view that conglomerates were likely to forebear from competition with those rivals they faced across multiple markets, for fear that price cutting in one market would lead to retaliation in another market, was commonplace among industrial organization economists in the 1960's. See generally' F. Scherer, Industrial Market Structure and Economic Performance 340-42 (2d ed. 1980). However, the hostility of antitrust law to conglomerate mergers in that decade was based largely on other theories-reflecting concerns with the opportunity for reciprocal dealing, the elimination of potential competition, an increase in entry barriers, and the ability of large firms to predate against small rivals-that are considered implausible by Chicago School commentators and are not reflected in the current Department of justice Merger Guidelines. See R. Bork, ThE Antitrust Paradox: A Policy at War with Itself 246-62 (1978) (Chicago School critique of theories underlying challenges to conglomerate mergers); Bauer, Government Enforcement Policy of Section 7 of the Clayton Act: Carte Blanche for Conglomerate Mergers?, 71 CaLif. L. Rev. 348 (1983) (treatment of conglomerate merger theories in D.O.J. Guidelines); but of. 5 P. AreEdA \& D. Turner, ANTITRUST LAW I 1114 (1980) (conglomerate mergers may harm competition by extending the area of oligopolistic interdependence). The recent revival of interest in theories of conglomerate forebearance includes both theoretical treatments, P. Woodward, Conglomerate Mergers with Tacit Collusion (Nov. 6, 1988) (unpublished manuscript); B. Bernheim \& M. Whinston, Multimarket Contact and Collusive Behavior, Harvard Instituce for Economic Research Discussion Paper No. 1317 (1987), and empirical studies, P. Woodward, An Empirical Analysis of Multimarket Contact: Do These Connections Affect Price Behavior? (Nov. 9, 1988) (unpublished manuscript); Scott, Purposive Diversification as a Motive for Merger, InT'L J. Indus. Organization (1989) (forthcoming); Scoll, Multimarket Contact and Economic Performance, 64 Rev. Econ. \& STatistics 368 (1982). 
price wars, usually considered strong evidence of competition, may in fact reflect tacit collusion. ${ }^{49}$ Even if this critical economic scholarship grows in importance in legal commentary and judicial opinions, it will reinforce rather than replace the now orthodox efficiency orientation of antitrust law.

The present antitrust approach to mergers reflects the new emphasis of the courts on economic efficiency. ${ }^{50}$ The most important document expressing the new view of antitrust is the 1982 Merger Guidelines of the U.S. Department of Justice ("DOJ Guidelines") (which were revised slightly in 1984). ${ }^{51}$ The new DOJ Guidelines differ from the prior practice in analyzing mergers under the antitrust laws in several respects. Most importantly, the DOJ Guidelines adopt an approach to market definition that takes into account both supply and demand substitutability: a market is defined as the smallest group of products within a geographic area such that sellers would be capable of raising price significantly were the group of firms to act cooperatively, as a "hypothetical monopolist."52 Goods sold at more distant geographic locations and goods less perfectly substitutable (whether demand substitutes or supply substitutes) ${ }^{53}$ are added to a proposed market definition until a hypothetical cartel is created which could in principle raise price a "small but significant and nontransitory" amount. ${ }^{54}$ The Department of Justice then examines whether a merger increases the risk of collusion in such a market, through measuring the increase in seller concentration ${ }^{55}$ and considering other factors facilitating or frustrating collusion, including entry. ${ }^{50}$ In further agreement with the new efficiency-oriented attitude of the courts in preference to the prior populist view, the DOJ Guidelines have

49. Green \& Porter, Noncooperative Collusion Under Imperfect Price Information, 52 EconomeTRICA 87 (1984); Rotemberg \& Saloner, A Supergame-Theoretic Model of Price Wars During Booms, 76 AM. Econ. REV. 390 (1986).

50. See gemerally Leddy, Recent Merger Cases Refled Revolution in Antitrust Policy, Legal Times, Nov. 3,1986 , at 17 , col. 1 .

51. Antitrust Div., Dep't of Justice, Merger Guidelines, 47 Fed. Reg. 28,493 (1982) [hereinafter 1982 Merger Guidelines]; 49 Fed. Reg. 26,823 (1984) [hereinafter 1984 Merger Guidelines]. The Department of Justice issued these Guidelines to clarify its enforcement policy concerning acquisitions and mergers subject to antitrust laws.

52. See 1984 Merger Guidelines, supra note 51, $\$$ 2.0, 2.11, 2.2, 2.31.

53. The Department of Justice incorporates supply substitutability into market definition in several ways. Most importantly, it broadens product markets when required by production flexibility. 1984 Merger Guidelines, supra note 51, $\$ 2.21$. However, the entire current sales of firms with production flexibility are not included in computing market shares when that amount overstates the potential additional supply that would be forthcoming from those firms if current producers were to raise price above the competitive level. Id. $\$ 2.4$. Similarly, geographic markets are broadened to include firms not directly competing with defendant producers, but selling in nearby areas, when a small price rise by defendants would induce these potential competitors to divert sales into the area presently served by defendants (a supply substitutability effect), as well as when the price rise would induce buyers to seek goods at more distant locations (a demand substitutability effect). See id. $\S \S 2.32(2),(6)$ (1984). Finally, the Department of Justice expressly recognizes the potential for foreign competitors to divert production into the United States in response to an anticompetitive domestic price increase. Id. $\$ \S 2.4,3.23$.

54. Id. $\S \S 2.11,2.31$ (defining product market and geographic market).

55. The DOJ Guidelines rely on the Herfindahl-Hirschman Index ("HHI') to measure market concentration. This index is computed as the sum of the squares of the market shares of the individual firms in the relevant market. Id. $\S 3.1$.

56. Id. $\S \S 3.3,3.4$. 
backed off from the rigid reliance on market shares characteristic of both Department of Justice enforcement policy and judicial decisions of the 1960 's, ${ }^{57}$ have given new emphasis to the role of entry in deterring the exercise of market power, ${ }^{58}$ and have raised the concentration threshold above which horizontal mergers merit antitrust concern. ${ }^{59}$

Not surprisingly, many horizontal mergers that would likely have been challenged under the enforcement standards of the 1960's have been cleared by the Department of Justice and Federal Trade Commission in the 1980's. ${ }^{60}$

57. Compare 1968 Merger Guidelines $§ 2$, reprinted in Horizontal Mergers, supra note 35, at app. A (analysis of market structure, principally the number of substantial sellers and the relative sizes of their market shares, is conclusive determinant of antitrust liability in all but "certain exceptional circumstances"), with 1982 Merger Guidelines, supra note 51, \$§ III(B), (C) (greater weight to ease of entry and other factors facilitating collusion); compare United States v. Philadelphia Nat'l Bank, 374 U.S. 321,363 (1963) (concentration creates presumption of anticompetitive effect), with United States v. General Dynamics Corp., 415 U.S. 486, 501-02 (1974) (market shares are "relevant as a prediction of future competitive strength" but may be misleading); see generally Horizontal Mergers, supra note 35, at 28-50, 165-75.

58. The DOJ Guidelines incorporated ease of entry into the market power calculus before the courts. 1982 Merger Guidelines, supra note 51, § III(B); 1984 MerGer Guidelines, supra note 51, $\S 3.3$; see supra note 43 (leading court decisions postdate Guidelines).

59. Compare United States v. Von's Grocery Co., 384 U.S. 270 (1966) (holding illegal a grocery chain merger among firms with a combined market share of $7.5 \%$ ), and 1968 MERGER GUIDELiNES, supra note 57, $\S 5-6$ (indicating intent to challenge acquisitions of firms with market shares under 5\%), with 1982 MERGER GuIDELINES, supra note 51, § III.A.l (raising concentration thresholds) (1984 Merger Guidelines, supra note 51, \$ 3.11); see generally Horizontal Mergers, supra note 35, at 19598 (practical effect of General Dynamics and the 1982 DOJ Guidelines was to raise concentration thresholds required for intervention); but see Hospital Corp. of Am. v. FTC, 807 F.2d 1381, 1385-86 (7th Cir. 1986) (Posner, J.) (Von's Grocery arguably remains authoritative, according to a leading proponent of Chicago School antitrust views), cert. denied, $107 \mathrm{~S}$. C. 1975 (1987). The connection between concentration and likelihood of collusion has been challenged by economists who argue that highly concentrated industries could be more profitable because they reflect the achievement of superior product design, lower costs, or other economic efficiencies. See generally F. SCHERER, Industrial Market Structure and Economic Performance 288-92 (2d ed. 1980 ).

60. Leddy, Recent Merger Cases Reflect Revolution in Antitrust Policy, Legal Times, Nov. 3, 1986, at 17, col. 1 ("Even the casual observer of the antitrust scene knows that [enforcement agencies] both are filing fewer and fewer merger cases, and that the cases they do file generally involve very highly concentrated markets with five or fewer firms.' '); see Sims \& Lande, New Forces Chip Away at Agencies' Policy of Antitrust Abandonment, Legal Times, Apr. 20, 1987, at 14, col. 1 ("Merger enforcement is undeniably looser today than a decade ago."). Chicago School scholars first led both enforcement agencies in the early 1980's, when President Reagan named William F. Baxter to head the Antitrust Division and appointed James C. Miller as Chairman of the Federal Trade Commission. More recent agency heads have similarly been sympathetic to Chicago School positions.

Chicago School ideas have led to a liberalization of merger enforcement standards and are the primary reason for the recent permissiveness of the enforcement agencies. Yet, some decline in enforcement activity would likely have occurred had standards not been relaxed and had the number of mergers not increased. See K. Davidson, supra note 35, at 143-45 (documenting merger wave beginning in late 1970's). The 1970's and 1980's saw the broadening of many economic markets from nationwide, where they were concentrated, to worldwide, where they were unconcentrated. In consequence, some transactions which would not have been permitted wo decades ago are allowed today. Compare United States v. LTV Corp., 1984-2 Trade Cas. (CCH) \& 66,133 (D.D.C. 1984) (impact of foreign steel imports on domestic steel prices supports consent judgment allowing merger of second and sixth largest domestic steel producers), with United States v. Bethlehem Steel Corp., 168 F. Supp. 576 (S.D.N.Y. 1958) (prohibiting merger of second and sixth largest domestic steel producers because of concentration in regional and national markets). In future decades, world markets are likely to grow more concentrated. Then broadening geographic markets will no longer reduce market concentration figures to less troubling levels, and more mergers will receive close scrutiny even if current standards of antitrust review are not changed. In such cases, limitations on the ability of U.S. enforcers to obtain pre-merger notification, jurisdiction, discovery, and relief when 
In addition, the enforcement agencies now exhibit substantially less concern with vertical and conglomerate mergers than did their counterparts in the 1960 's, ${ }^{61}$ consistent with Chicago School interpretations of these acquisitions as efficient rather than anticompetitive.

\section{B. Antitrust and Health Care}

1. Interstate Commerce. In the past two decades, the number of antitrust cases involving the health care industry has grown dramatically. This explosion followed on the heels of two Supreme Court decisions in the mid1970's: the 1975 decision in Goldfarb v. Virginia State Bar ${ }^{62}$ and the 1976 decision, Hospital Building Co. v. Trustees of Rex Hospital. ${ }^{63}$ Goldfarb applied the Sherman Act to the "learned professions,"64 and Rex Hospital applied it to hospitals operating in small market areas. ${ }^{65}$ Taken together, these decisions confirmed that the Sherman Act section $1^{66}$ requirement that a restraint of trade lie in or affect interstate commerce does not bar application of that law to the health care industry. ${ }^{67}$ Furthermore, in 1980 Congress removed

some defendants are foreign are likely to raise enforcement difficulties that can be solved only by international cooperation.

61. See generally Halverson, An Overview of Legal and Economic Issues and the Relevance of the Vertical Merger Guidelines, 52 AnTitrust L.J. 49, 76-81 (1983).

62. 421 U.S. $773(1975)$.

63. 425 U.S. $738(1976)$.

64. 421 U.S. at 785-88; accord Arizona v. Maricopa County Medical Soc'y, 457 U.S. 332, 348-49 (1982) (price-fixing agreements among doctors "are not premised on public service or ethical norms," so merit no special antitrust treatment); $f$. Smith v. Northern Mich. Hosps., Inc., 703 F.2d 942,949 n.1 2 (6th Cir. 1983) (although the medical profession is not exempt from the antitrust laws, some professional practices might survive antitrust scrutiny under the rule of reason even though they are illegal in other contexts).

65. 425 U.S. at 743 (interstate commerce requirement satisfied if activity is in or "substantially and adversely affects interstate commerce") (quoting Gulf Oil Corp. v. Copp Paving Co., 419 U.S. 186, 195 (1974)); accord McLain v. Real Estate Bd., 444 U.S. 232, 242 (1980). Some circuits read MCLain as requiring that plaintiff prove a nexus between the challenged restraint on competition and interstate commerce, although that hurdle is readily satisfied. See, e.g., Crane v. Intermountain Health Care, Inc., 637 F.2d 715, 721 -22, 724 (10th Cir. 1980) (en banc); Stone v. William Beaumont Hosp., 782 F.2d 609, 617-20 (6th Cir. 1986) (Holschuh, J., concurring); Hayden v. Bracy, 744 F.2d 1338, 1343 n.2 (8th Cir. 1984). Other circuits interpret McLain less restricively, as holding that plaintiff need not demonstrate that the alleged violation affects interstate commerce so long as defendant's activity has an effect on interstate commerce. See, e.g., Shahawy v. Harrison, 778 F.2d 636, 640 (11th Cir. 1985); Turf Paradise, Inc. v. Arizona Downs, 670 F.2d 813, 818-19 (9th Cir.), cert. denied, 456 U.S. 1011 (1982); cf. Bunker Ramo Corp. v. United Business Forms, Inc., 713 F.2d 1272, $1280-82$ (7th Cir. 1983) (interstate commerce requirement is easily satisfied regardless of the interpretation of Mclain); P. Areeda \& H. Hovenkamp, Antitrust Law fl 232. la (Supp. 1987) (same).

66. 15 U.S.C. $\S 1$ (1982).

67. Perhaps the recent application of antitrust law to the health care industry should not have been surprising. See American Medical Ass'n v. United States, 317 U.S. 519, $528-29$ (1943) (practice of medicine regulated by the Sherman Act). It has long been established that the Sherman Act covers all practices that Congress is permitted to regulate pursuant to the commerce clause of the Constitution. United States v. South-Eastern Underwriters Ass'n, 322 U.S. 533, $557-59$ (1944). Furthermore, even before Goldfarb, the Federal Trade Commission "was starting to organize its health care program and had already begun an investigation into the issue of physician control over prepaid health care organizations." T. Calvani, Remarks Before the American Bar Association's Joint Program on Antitrust Issues in the Health Care Industry (Feb. 20, 1986), reprinted in 1986 Trade Reg. Rep. (CCH) \50,479, at 56,276 (1986). 
interstate commerce limitations on the reach of Clayton Act section 7 to permit the prospective antitrust review of mergers and acquisitions in or "affecting" interstate commerce. ${ }^{68}$ Today, these jurisdictional requirements of the antitrust laws do not present a significant hurdle to the application of antitrust to hospital mergers. ${ }^{69}$

2. Implied Repeal. The application of antitrust to the health industry has also been aided by the 1981 Supreme Court decision ${ }^{70}$ that Congress's health planning regulatory scheme, instituted in 1974 under the National Health Planning and Resources Development Act ("NHPRDA"), ${ }^{71}$ did not impliedly repeal the application of the antitrust laws to the health care field. ${ }^{72}$ Thus, a state requirement that a hospital merger receive state certificate-of-need approval pursuant to NHPRDA mandates did not immunize the acquisition from judicial review under the antitrust laws. ${ }^{73}$

3. State Action. The state action exemption remains an important limitation to the scope of antitrust review of many hospital activities, perhaps including some hospital mergers. The exemption was established by the Supreme Court in 1943, in Parker v. Brown. ${ }^{74}$ In that decision, the Court held that Congress, in passing the antitrust laws, never intended to preempt state economic regulation restraining competition, so long as those restraints constitute "state action or official action directed by a state."75 The

68. 15 U.S.C. $\$ 18$ (1982); see generally ABA Antitrust Section, Antitrust Law Developments 148 n.4 (2d ed. 1984).

69. United States v. Hospital Affiliates Int'l, Inc., 1980-81 Trade Cas. (CCH) \63,721, at 77,853 (E.D. La. 1980); cf. City of Fairfax v. Fairfax Hosp. Ass'n, 562 F.2d 280, 283 (4th Cir. 1977) (monopolization case), vacated and remanded on other grounds, 435 U.S. 992 (1978); but cf. Proger, Antitrust Developments Affecting the Heallh Care Sector, 57 AnTitrust L.J. 315, 315 n.3 (1988) (collecting recent non-merger health care antitrust decisions in which the complaint was dismissed for lack of interstate commerce).

70. National Gerimedical Hosp. \& Gerontology Center v. Blue Cross, 452 U.S. 378 (1981).

71. Pub. L. No. 93-641, $\$ 3,88$ Stat. 2225, 2227-57 (1975) (some of these provisions were repealed by Pub. L. No. 99-660, 100 Stat. 3799 (1986)). The statute established "health systems agencies" ("HSA's"), advisory boards composed of health care consumers and providers, to develop health care plans for local areas in order to control health care costs. The statute also created statewide planning boards and required that each state establish a certificate-of-need process. See generally National Gerimedical, 452 U.S. at 383-85.

72. National Gerimedical, 452 U.S. at 393.

73. State of North Carolina v. P.I.A. Asheville, Inc., 740 F.2d 274, 279-85 (4th Cir. 1984) (en banc), cert. denied, 471 U.S. 1003 (1985); American Medical Int'l, Inc., 104 F.T.C. 1, 185-90 (1984); but see American Medical Int'l, Inc., 104 F.T.C. at 188 (refusing to decide whether implied immunity would have been appropriate had local planning agency expressly advocated "cost-saving cooperation among providers" pursuant to NHPRDA) (quoting National Gerimedical, 452 U.S. at 393 n.18); Groner, Hospilal Mergers, Health Planning, and the Antitrust Laws: A Principled Approach to Implied Repeal, 7 J. Legal MEd. 471 (1986) (suggesting that NHPRDA may shield some activities from antitrust laws); O'Neill, Antitrust and Nearby Hospital Combinations, 4 HealthSpan, May 1987, at 3, 7. Today, CON's are no longer required and have been abolished in many states. See supra notes 16-17, 22-23 and accompanying text.

74. 317 U.S. 341 (1943).

75. Id. at 351 . "In a dual system of government in which, under the Constitution, the states are sovereign, save only as Congress may constitutionally subtract from their authority, an unexpressed purpose to nullify a state's control over its officers and agents is not lightly to be attributed to 
exemption attempts to harmonize the national policy favoring competition embodied in the antitrust laws with constitutional principles of federalism. ${ }^{76}$

After Parker, the Court gave little attention to the state action doctrine until the mid-1970's. In 1980, after reviewing a flurry of Supreme Court state action decisions from the end of the previous decade, the Court concluded that the state action exemption applies only to restraints on competition that are (1) "clearly articulated . . as state policy" and (2) "actively supervised" by the state. ${ }^{77}$ In two cases decided in the 1980's, the Court added a threshold requirement to this two part test: a state regulation must be "facially inconsistent" with the antitrust laws before a court can hold that regulation to have been preempted by Congress, and thus before it can address whether the state action exemption will apply. ${ }^{78}$ This threshold requirement appears not to restrict significantly the scope of the exemption. ${ }^{79}$

Congress." Id.; c.f. Community Communications Co. v. City of Boulder, 455 U.S. 40, 62 (1982) (Rehnquist, J., dissenting) (state action questions are preemption rather than exemption issues).

76. See id. at 352; cf. City of Lafayette v. Louisiana Power \& Light Co., 435 U.S. 389, 421 (1978) (Burger, C.J., concurring in part) (Parker is "grounded on principles of federalism"); see generally P. Areeda \& H. Hovenkamp, supra note 65, at $1212.1 \mathrm{f}$.

In response to recent commentary arguing that the state action exemption should be narrowly construed in order to allow wide scope to free market principles underlying the antitrust laws, one author endorses the state action principle as a bulwark against "a return to the era the Court left behind when it repudiated Lochner v. New York[, 198 U.S. 45 (1905)]." Garland, Antitrust and State Action: Economic Efficiency and the Political Process, 96 Y ALE L.J. 486, 488 (1987). Garland correctly emphasizes that a reduction in the breadth of state action immunity comes at the price of reduced deference to the independent regulatory role of the states in a federal system. However, if the judicial branch sets out to strike down state regulatory legislation in order to expand the scope of free market contracting, it is unlikely to implement this program through construction of the antitrust laws, which Congress can readily amend to protect state power. Wiley, Revision and Apology in Antitrust Federalism, 96 Y ALE L.J. 1277 (1987) (response to Garland). Rather, this program would be implemented through the construction of constitutional provisions. See R. EPSTEIN, Takings: Private Property and the Power of Eminent Domain (1985); B. Siegan, Economic Liberties and The Constitution (1980); see generally Baker, Has the Contract Clause Counter-Revolution Halted? Rhetoric, Rights, and Markets in Constitutional Analysis, 12 Hastings Const. L.Q. 71 (1984).

77. California Retail Liquor Dealers Ass'n v. Midcal Aluminum, Inc., 445 U.S. 97, 105 (1980); accord Patrick v. Burget, 108 S. Ct. 1658, 1663 (1988) ("Only if an anticompetitive act of a private party meets both of these requirements is it fairly attributable to the State."); Southern Motor Carriers Rate Conference v. United States, 471 U.S. 48, 57, 61 (1985) (state compulsion not required if state actively supervises regulatory schemes); see Parker, 317 U.S. at 351 ("a state does not give immunity to those who violate the Sherman Act by authorizing them to violate it, or by declaring that their action is lawful").

78. Fisher v. City of Berkeley, 475 U.S. 260, 262, 264-65, 270 (1986); Rice v. Norman Williams Co., 458 U.S. 654, 659-62 (1982); but of. P. AREeda \& H. Hovenkamp, supra note 65, at 1209.2 , at 84 85 (Rice threshold and Parker tests viewed as successive steps in a preemption analysis, thus, "[i]f the state statute appears to be preempted under Rice because it creates serious restraints, it can nevertheless be saved from preemption by satisfying Parker").

79. Fisher and Rice likely stand for no more than the unremarkable proposition that Congress, in passing the antitrust laws, did not automatically preempt all state or municipal regulations with deleterious consequences for economic efficiency. Accord Parker, 317 U.S. at 351 (finding "no suggestion of a purpose to restrain state action in the [Sherman] Act's legislative history"); $f$. Page, Interest Groups, Antitrust, and State Regulation: Parker v. Brown In the Economic Theory of Legislation, 1987 DUKE L.J. 618, 620-2 I (state action doctrine permits "judicial deference to state economic choices whose costs and benefits fall primarily on the citizens of the state"). The Court in Fisher held that landlord actions undertaken pursuant to a municipal rent control ordinance could not be challenged as antitrust violations even though their effect on competition would be similar to that of other actions that would clearly violate the antitrust laws (such as a concerted agreement by landlords to lower rents in order to benefit tenants). Had the rent control ordinance reviewed in Fisher instead 
The state action exemption may be asserted by private parties acting pursuant to state regulation. ${ }^{80}$ These regulatory schemes may be created and supervised by state legislatures, or they may be created and supervised by state agencies and political subdivisions. ${ }^{81}$ It is not necessary that the state supervise the regulatory schemes of municipalities or agencies for actions undertaken pursuant to those regulatory schemes to invoke the state action exemption. $^{82}$ In those cases, however, the municipality or agency must "actively supervise" the regulatory scheme for the defense to apply. ${ }^{83}$ Moreover, the state action exemption is predicated on state regulation. State ownership of the entity engaging in the alleged restraint of trade is analytically irrelevant to the determination of the application of the exemption. ${ }^{84}$ State ownership may in practice, however, be associated with substantial state supervision.

In antitrust litigation concerning hospital mergers, the most plausible argument for invoking the state action exemption is that a state's CON process, required in many states for hospital consolidation, allows mergers to be undertaken pursuant to a clearly articulated and actively supervised state

required landlords to cooperate to fix prices, or ratified concerted landlord action (recalling Midcal), the threshold test would have been met and the Court would then have considered whether the state action exemption applied. See Rice, 458 U.S. at 662, $662 \mathrm{n} .9$ (state statute is preempted only if it requires firms to violate antitrust laws; if statute merely authorizes such conduct without compelling it, firm actions are subject to antitrust review). Cf. Bates v. State Bar of Arizona, 433 U.S. 350, 359-63 (1977) (state bar association disciplinary rule restricting lawyer advertising exempt because promulgatated by state agency pursuant to clearly articulated policy and supervised actively during enforcement proceedings). In its most recent state action decision, the Court ignored the threshold requirement. Patrick v. Burget, 108 S. Ct. 1658 (1988).

80. Southerm Motor Carriers, 471 U.S. at 61.

81. Fisher, 475 U.S. at 264-65; Town of Hallie v. City of Eau Claire, 471 U.S. 34, 40 (1985); Community Communications Co. v. City of Boulder, 455 U.S. 40, 52 (1982); City of Lafayette v. Louisiana Power \& Light Co., 435 U.S. 389, 415 (1978).

82. Hallie, 471 U.S. at 46-47 (municipality); Humana of Illinois, Inc. v. Board of Trustees of Southern Illinois University, 1986-1 Trade Cas. (CCH) I 67,127, at 62,804-05 (C.D. Ill. 1986) (agency); $(f$. St. George's School of Med. v. Department of Registration and Educ., 640 F. Supp. 208, 211 (N.D. Ill. 1986) (state agency conduct exempt when agency is supervised by legislature, through ability to amend statutes, and by state courts, through administrative review.)

83. Patrick v. Burget, 108 S. Ct. 1658 (1988) (Oregon did not actively supervise hospital peer review committee because no state agency was empowered to review private peer review decisions and overturn those not in accord with state policy); Humana of Illinois, 1986-1 Trade Cas. (CCH) at 62,806 (hospital may invoke state action immunity because it was actively supervised by state university); see Hallie, 471 U.S. at $46 \mathrm{n} .10$ ("where state or municipal regulation by a private party is involved, however, active state supervision must be shown, even where a clearly articulated state policy exists"); see generally P. AREEDA \& H. HOVENKAMP, supra note 65, at "iा 212.9 a, b. Under some circumstances, judicial review will constitute adequate supervision. Bolt v. Halifax Hosp. Medical Center, 851 F.2d 1273 (11 th Cir.), vacated and petition for reh 'g en banc granted, 861 F.2d 1233 (11 th Cir. 1988).

84. Cf. Coastal Neuro-Psychiatric Assocs. v. Onslow Memorial Hosp., 795 F.2d 340 (4th Cir. 1986) (state ownership of hospital is not a factor in allowing the state action exemption for a county hospital's decision to limit doctor access to equipment); Jiricko v. Coffeyville Memorial Hosp. Medical Center, 628 F. Supp. 329 (D. Kan. 1985) (state action exemption does not bar antitrust claims against state owned hospital because Kansas hospital operations do not constitute a public function); but of. Limeco, Inc. v. Division of Lime, 778 F.2d 1086, 1087 (5th Cir. 1985) (state action exemption applies to state agency acting as competitor in a commercial activity). 
policy ${ }^{85}$ In an en banc opinion addressing this question, the Fourth Circuit held that a North Carolina CON program instituted pursuant to the NHPRDA, requiring state regulatory approval of hospital acquisitions, failed to meet the ongoing state supervision predicate for the state action exemption. ${ }^{86}$ The Fourth Circuit emphasized that the state CON procedure provided for no regulation of post-acquisition prices and no penalties for non-compliance with state regulation. ${ }^{87}$ Thus, a state could create a regulatory scheme to displace competition when necessary to effectuate other state policies, ${ }^{88}$ which would exempt from antitrust scrutiny acquisitions made pursuant to regulatory mandates, although North Carolina did not do so. ${ }^{89}$

\section{Intra-enterprise Cooperation. In Copperweld Corp. v. Independence Tube Corp., ${ }^{90}$} the Supreme Court held that a corporate parent and its wholly owned subsidiary are a single enterprise under the Sherman Act section 1,91 incapable of combining in restraint of trade. In reaching this conclusion, the Court emphasized that both a parent firm and its subsidiary have the identical goal of maximizing profits for the enterprise as a whole, so never exhibit the independent and competitive decisionmaking which the antitrust laws protect. ${ }^{92}$ Although the narrow holding of Copperweld leaves open the question of whether two wholly owned affiliates with a common parent are incapable of conspiring together, the Court's rationale readily encompasses this case. ${ }^{93}$ Thus, the theory of Copperweld appears to exempt corporate reorganizations involving wholly owned affiliates from review under both the Sherman Act section 1 and the Clayton Act section 7.94

85. State action limited to state financing (through use of industrial development borrowing authority) and state ownership of the hospital facility, without state management, is insufficient to satisfy the requirements for the state action exemption. See City of Fairfax v. Fairfax Hosp. Ass'n, 562 F.2d 280, $284-85$ (4th Cir. 1977) (monopolization case), vacated, 435 U.S. 992 (1978).

86. North Carolina v. P.I.A. Asheville, Inc., 740 F.2d 274 (4th Cir. 1984) (en banc), cert denied, 471 U.S. 1003 (1985); $f$. General Hosp. of Humana, Inc. v. Baptist Medical System, 1986-1 Trade Cas. (CCH) I 66,996, at 62,116-17 (E.D. Ark. 1986) (Arkansas CON procedure satisfies active supervision requirement so alleged anticompetitive conduct of defendant hospital in causing the state not to approve plaintiff hospital expansion is sheltered by state action exemption).

87. P.I.A. Asheville, 740 F.2d at 278.

88. For example, a state might wish to allow a hospital merger even though the transaction raises substantial antitrust questions, if the new entity agrees to keep open a hospital in a poorly served region that otherwise would close or agrees to serve patients unable to pay.

89. Had North Carolina directly regulated hospital prices and services as well as major capital investments, the argument for ongoing state supervision of the regulatory scheme would have been much stronger, and thus the state action exemption may well have insulated the acquistion from antitrust review. See California Retail Liquor Dealers Ass'n v. Midcal Aluminum, Inc., 445 U.S. 97, 105-06 (1980) (state could require resale price maintenance in violation of federal antitrust laws if state regulated prices).

90. 467 U.S. 752 (1984).

91. 15 U.S.C. $\$ 1(1982)$.

92. See Copperweld, 467 U.S. at 768-69, 771.

93. Hood v. Tenneco Texas Life Ins. Co., 739 F.2d 1012, 1015 (5th Cir. 1984); HRM, Inc. v. Tele-Communications, Inc., 653 F. Supp. 645, 647 (D. Colo. 1987); Gucci v. Gucci Shops, Inc., 651 F. Supp. 194, 197-98 (S.D.N.Y. 1986); but see In re Ray Dobson's Lincoln-Mercury, Inc., 604 F. Supp. 203, 205 (W.D. Va. 1984).

94. Cf. Copperveld, 467 U.S. at 777. ("A corporation's initial acquisition of control will always be subject to scrutiny under $\S 1$ of the Sherman Act and $\S 7$ of the Clayton Act . . . Thereafter, the 
After Copperweld, it could be argued that the consolidation of two hospitals owned and managed by differing affiliates of the same religious organization, such as a merger between hospitals run by different religious orders within the Catholic Church, would be exempt from antitrust review as the actions of a single enterprise. Copperweld does not compel this result, however. Affiliated nonprofit organizations, unlike the for-profit enterprise considered in Cooperweld, may have competing or multiple interests which can lead them to act in ways inconsistent with obtaining the maximum pecuniary return to their umbrella group as a whole. ${ }^{95}$ Thus, a hospital run by the Sisters of Mercy may compete with a hospital run by the local Catholic diocese, and a merger between the two hospitals could have anticompetitive consequences, even though the bodies governing the operations of each hospital owe ultimate allegiance to the same church.

A sensible policy for vindicating hospital competition in merger analysis, consistent with the broad thrust of Copperweld, would treat affiliated nonprofit hospitals as separate entities for the purpose of the antitrust review of their merger if they are controlled independently, have independent interests, and make independent competitive decisions on the facts of the case. ${ }^{96}$ Such a policy should be applied consistently: If affiliated nonprofit hospitals would be considered separate entities if they merged, they should not be aggregated in computing market shares in connection with the analysis of an unrelated acquisition in their market. ${ }^{97}$

enterprise is fully subject to $\S 2$ of the Sherman Act and $\S 5$ of the Federal Trade Commission Act ... to control dangerous anticompetitive conduct.").

95. Note, Antitust and Nonprofit Entities, 94 Harv. L. Rev. 802, 811-12 (1981); of. Marjorie Webster Junior College v. Middle States Ass'n of Colleges \& Secondary Schools, 432 F.2d 650, 654 (D.C. Cir.) (nonprofit firm may have non-commercial purposes), cert. denied, 400 U.S. 965 (1970); Sonitrol of Fresno, Inc. v. AT\&T Co., 1986-I Trade Cas. (CCH) ף 67,080, at 62,567-68 (D.D.C. 1986) (partially owned subsidiaries of a for-profit firm are capable of conspiring with their parent or each other, despite parent de facto control, because common purpose is absent).

96. In deciding whether affiliated church hospitals are a single entity under Sherman Act $\S 1$, for example, courts should look to factors such as the presence of overlapping executives or directors, the degree of supervision of rates, hiring, capital expenditures, and service offerings by common church superiors, and the historical independence of the relevant church bodies governing hospital activities. But see Proctor v. General Conference of Seventh-Day Adventists, 651 F. Supp. 1505, 1524 25 (N.D. III. 1986) (church units held part of single, unified body with unity of purpose; rejecting evidence on how church operates in practice or theory); Zimmerman v. Board of Publications of the Christian Reformed Church, 598 F. Supp. 1002, 1010 (D. Colo. 1984) (church and its publications board act as single entity, incapable of conspiring); $c$. Photovest Corp. v. Fotomat Corp., 606 F.2d 704, 726-27 (7th Cir. 1979) (similar factors proposed for test of intra-enterprise conspiracy among for-profit firm affiliates), cert. denied, 445 U.S. 917 (1980), disapproved in Copperweld, 467 U.S. at 772 n. 18.

97. See infra notes 267-74 and accompanying text (market share measures). Furthermore, if affiliated nonprofic hospitals could be separate entities capable of violating the antitrust laws through merger, then their merger should be subject to pre-merger notification to allow the enforcement agencies the opportunity to investigate the issue. The FTC currently interprets the Hart-ScottRodino Act, Pub. L. No. 94-435, § 201, 90 Stat. 1381, 1390-94 (1976) (codified at 15 U.S.C. $\$ 18 a$ (1982)), to require pre-merger notification of a transaction between affiliated nonprofit hospitals not controlled by the same entity, as with a merger of hospitals run by distantly related institutions within the same church. See 16 C.F.R. $\$ \S 801.1$ (a)(1), (a)(3), (b) (FTC definitions of person, ultimate parent entity, and control). 
5. Nonprofit Institutions. Half of all U.S. hospitals are organized as private nonprofit institutions, ${ }^{98}$ and an even larger fraction of hospital beds are controlled by private nonprofits. ${ }^{99}$ A nonprofit entity is not subject to Federal Trade Commission jurisdiction under the FTC Act unless the entity is organized to carry on business for the profit of its members. ${ }^{100}$ This proscription prevents the Commission from bringing an enforcement action against a merger between nonprofit hospitals under FTC Act section 5. ${ }^{101}$ However, the FTC may apparently bring enforcement actions against nonprofits under Clayton Act section 7, as the Clayton Act provides an independent basis for FTC actions. ${ }^{102}$

The prohibitions of Clayton Act section 7 apply to many nonprofits, although that statute may not reach some transactions challengable under Sherman Act section 1. Clayton Act section 7 permits the government and private plaintiffs to challenge stock acquisitions by nonprofit hospitals. Section 7 also arguably authorizes enforcement actions against asset acquisitions among nonprofit firms, ${ }^{103}$ although the limited authority on this

98. In 1984, 51\% of U.S. hospitals were under nonprofit control, $15 \%$ were under proprietary control, and $34 \%$ were under governmental control. See 1987 Statistical ABSTRACT, supra note 2, at 93; $c$. Frech, Comments on Antitrust Issues, 7 Advances in Health Economics and Health Services RESEARCH 263, 265 (1987) (historical reasons for domination of nonprofit hospitals no longer apply; nonprofit form now anachronistic).

99. In 1975, 69.6\% of all hospital beds were controlled by private nonprofit hospitals, $22.7 \%$ by government hospitals, and only $7.7 \%$ by for-profit hospitals. White, The American Hospital Indusiry Since 1900: A Short History, 3 Advances in Health Economics and Health Services Research 143, 149 (1982).

100. 15 U.S.C. $\$ 44$ (1982). Thus, the FTC may exercise jurisdiction over the "business aspects" of the nonprofit American Medical Association's activities on behalf of member physicians "even if [those aspects] are considered secondary to the charitable and social aspects of their work." American Medical Ass'n v. FTC, 638 F.2d 443, 448 (2d Cir. 1980), aff'd per curiam by an equally divided Court, 455 U.S. 676 (1982).

101. 15 U.S.C. $\$ 45$ (1982). But see Miles, Hospital Mergers and the Antitrust Laws: An Overview, 29 ANTITRust Bull. 253, 261-62 (1984) (evaluating argument that hospitals are subject to FTC jursidiction because they are in reality for-profit physician cartels). Furthermore, if either the acquiring or acquired firm is a for-profit entity, the FTC apparently could seek to halt the merger under FTC Act $\$ 5$ prior to its consumation by suing to enjoin that one party.

102. Clayton Act $\S 11,15$ U.S.C. $\S 21$ (1982), authorizes the FTC to enforce Clayton Act $\S 7,15$ U.S.C. $\$ 18$ (1982), directly. In re Adventist Health System/West, File No. 881-0122 (F.T.C. Mar. 15, 1989) (order denying petition to quash subpoena), request for full Commission review denied, F.T.C. Apr. 10, 1989; cf. United States v. Philadelphia Nat'l Bank, 374 U.S. 321,348 (1963) (Clayton Act “explicitly enlarged the FTC's jurisdiction").

103. Clayton Act $\S 7,15$ U.S.C. $\S 18$ (1982), proscribes all anticompetitive stock acquisitions and anticompetitive asset acquisitions by persons subject to FTC jurisdiction. The Supreme Court has held that the limitation on covered asset acquisitions does not prevent a suit under Clayton Act $\S 7$ to bar asset acquisitions among banks, an industry over which the FTC has no jurisdiction under FTC Act $\$ 5,15$ U.S.C. $\$ 45(\mathrm{a})(2)$ (1982), unless the asset acquisition falls short of merger. United States v. Philadelphia Nat'l Bank, 374 U.S. 321,344 (1963). The Court emphasized that mergers resemble stock acquisitions in purpose and effect more closely than they resemble a "pure purchase of assets," even when they take the contractual form of an asset acquisition. Id. at 345-46. On similar reasoning, mergers among nonprofits that take the form of an asset acquisition are most likely included within the scope of Clayton Act $\$ 7$ even though the FTC Act does not award the Commission jurisdiction over nonprofits, and even if the nonprofit is created without the "stock"

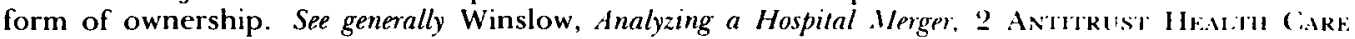
Chronicle 4, 8-9 (1988). 
issue is in conflict. ${ }^{104}$ To the extent that nonprofit hospital acquisitions are exempt from review under that statute the FTC will be unable to challenge them. Regardless of the reach of Clayton Act section 7, mergers among nonprofit firms are subject to antitrust review under the Sherman Act, as nonprofits are not exempt from the antitrust laws merely because of their form of ownership or corporate purpose. ${ }^{105}$

The standard of review for acquisitions challenged under Clayton Act section 7 is arguably more difficult to satisfy than the standard applied to mergers under Sherman Act section 1, because section 7 is intended to halt restraints of trade in their incipiency while section 1 applies only to those agreements actually restraining trade. ${ }^{106}$ Under the current application of these statutes to acquisitions, however, the practical distinction between them is small. ${ }^{107}$ In consequence, the nonprofit status of merging hospitals does not significantly limit the antitrust review of their actions, although uncertainty regarding FTC jurisdiction or the reach of section 7 may cause governmental enforcement against non-profits to take the form of a Justice Department suit brought under Sherman Act section 1. ${ }^{108}$

\section{Other Exemptions. Two other avenues for obtaining antitrust exemptions} seem unlikely to apply to hospital mergers, although they may immunize some hospital activities from antitrust review. These are exemptions for the "business of insurance,"109 and for the cooperative solicitation of

104. Compare United States v. Rockford Memorial Corp., 1989-1 Trade Cas. (CCH) \& 68.462 (section 7 reaches non-stock mergers accomplished by persons not under the jurisdiction of the FTC), appeal fled, with United States v. Carilion Health System, 707 F. Supp. 840, 841 \& r.1 (W.D. Va. 1989) (referring to Sept. 30, 1988, order granting in part defendants' motion to dismiss) (United States may not seek to enjoin merger of non-profit hospitals under Clayton Act $\$ 7$ ), appeal filed, No. 89-2625 (4th Cir. 1989); cf. Hospital Corp. of Am. v. FTC, 807 F.2d 1381, 1390 (7th Cir. 1986) ("There is a possible gap in the FTC's jurisdiction over acquisitions involving nonprofit corporations."), cert. denied, 481 U.S. 1038 (1987).

105. American Soc'y of Mechanical Eng'rs, Inc. v. Hydrolevel Corp., 456 U.S. 556, 576 (1982); $c f$. Note, Antitrust and Nonprofi Entities, 94 HARv. L. REv. 802 (1981) (advocating application of antitrust laws to nonprofits identically with their application to for-profit firms, regardless of the nonprofit's goals, except to the extent the nonprofit corrects a market failure); but of. Arthur, Farewell to the Sea of Doubt: Jettisoning the Constitutional Sherman Act, 74 CallF. L. REv. 266, 278, 348-49 (1986) (doubting whether Congress intended to address anticompetitive activities by nonprofits in passing the Sherman Act).

106. Brown Shoe Co. v. United States, 370 U.S. 294, 318,318 n. 33 (1962); see United States v. Penn-Olin Chem. Co., 378 U.S. 158, 170-71 (1964).

107. 2 P. Areeda \& D. Turner, Antitrust LaW $\$ 304$ (1978).

108. Carilion, 707 F. Supp. 840, 841, 846-47 (W.D. Va. 1989) (United States may seek to enjoin merger of nonprofit hospitals under Sherman Act $\$ 1$ ), appeal fled, No. 89-2625 (4th Cir. 1989); see United States v. First Nat'l Bank \& Trust Co., 376 U.S. 665, 671 -72 (1964) (merger of for-profit firms violates $\$ 1)$. As the FTC enforces Sherman Act $\$ 1$ only through its incorporation into FTC Act $\$ 5$, this approach is not open to it. 2 P. Areeda \& D. TURner, supra note 107, at 9 ף 303, 305c, 307.

Furthermore, mergers involving nonprofit hospitals meeting the size-of-parties or size-oftransactions tests must be reported under the pre-merger notification provisions of the Hart-ScottRodino Act, unless they are transfers to or from a federal, state, or local governmental agency. 15 U.S.C. $\S 18$ a (1982); 16 C.F.R. $\$ 801.2(d)$ (1988). However, certain joint ventures among nonprofits need not be reported. 16 C.F.R. $\$ 802.40$ (1988).

109. 15 U.S.C. $\S \S 1012(b), 1013$ (b) (1982) (McCarran-Ferguson Act). To be found exempt, the activity must also be regulated by state law, and not constitute coercion or a boycott. This exemption has been construed narrowly in the health care field. Group Life \& Health Ins. Co. v. Royal Drug Co., 
governmental action. ${ }^{110}$ Also, defendant hospitals have unsuccessfully taken the remarkable position that the absence of price competition in the hospital industry should insulate a hospital acquisition from antitrust scrutiny. ${ }^{111}$

\section{The Antitrust Analysis of Hospital Mergers}

The mainstream approach to merger review in the 1980's, as expressed in the DOJ Guidelines, attempts to determine whether a reduction in the number of firms in a market substantially increases the likelihood of collusion or other anticompetitive consequences. ${ }^{112}$ The standard approach proceeds in three steps: (1) defining the relevant market(s) in which anticompetitive consequences from a merger could arise; (2) identifying the firms within each market and examining their market shares to infer the likelihood of anticompetitive effects from an acquisition; and (3) adjusting that inference by considering other factors affecting the ability of the firms to collude, including ease of entry. ${ }^{113}$ As will be seen, the current hospital regulatory scheme has important consequences for the antitrust analysis of hospital mergers, both directly and indirectly, through its influence on industry structure.

440 U.S. 205 (1979) (reimbursement agreement between Blue Shield and pharmacies providing drugs to insured consumers falls outside the business of insurance); Union Labor Life Ins. Co.v. Pireno, 458 U.S. 119 (1982) (holding that insurer's use of peer review process to determine reasonableness of health care provider reimbursements is subject to antitrust review); $c$. KlamathLake Pharmaceutical Ass'n v. Klamath Medical Serv. Bureau, 701 F.2d 1276 (9th Cir.), cert. denied, 464 U.S. 822 (1983) (health insurer's operation of pharmacy held "business of insurance").

110. The Noerr-Pennington doctrine awards immunity to cooperative solicitation of government action, as an exercise of first amendment freedoms. Eastern R.R. Presidents Conference v. Noerr Motor Freight, Inc., 365 U.S. 127 (1961); United Mine Workers v. Pennington, 381 U.S. 657 (1965); accord Mercy-Peninsula Ambulance, Inc. v. County of San Mateo, 592 F. Supp. 956, 967 (N.D. Cal. 1984) (alleged conspiracy to create paramedic monopoly through influencing county government protected from antitrust review), aff'd on other grounds, 791 F.2d 755 (9th Cir. 1986). This exemption presents a difficulty for antitrust enforcers attempting to challenge cases involving non-price predation that employs the political process. See, e.g., General Hosps. of Humana, Inc. v. Baptist Medical System, 1986-1 Trade Cas. (CCH) \ 66,996, at 62,117-18 (E.D. Ark. 1986); see generally R. Bork, supra note 37, at 144-60; Calvani, Non-Price Predation: A New Antitrust Horizon, 54 Antitrust L.J. 409 (1985). For example, this exemption apparently allows hospitals to solicit cooperatively rate increases under state or federally run prospective reimbursement schemes, even though this limited cooperation might facilitate collusion over the rates charged for the same procedures to classes of patients for which hospital rates are unregulated.

111. American Medical Int', 104 F.T.C. 1, 179-80 (1984) (even if hospitals did not compete, although in fact they do, antitrust law would apply absent congressionally mandated exemption).

112. Merger review is prospective under the Clayton Act, and thus is concerned with likely future conduct rather than past conduct. 15 U.S.C $\$ 18$ (1982) (proscribing acquisitions when their effect "may be substantially to lessen competition, or to tend to create a monopoly"). The historical development of the antitrust proscriptions governing horizontal mergers is described in HorIzONTAL Mergers, supra note 35, at 28-50. The mainstream approach of the DOJ Guidelines may be understood as an economic efficiency-oriented interpretation of the leading Supreme Court decisions on merger analysis. United States v. General Dynamics Corp., 415 U.S. 486 (1974); United States v. Philadelphia Nat'l Bank, 374 U.S. 321 (1963).

113. See 1984 Merger Guidelines, supra note $51, \S \S 2,3$. 


\section{A. The Possible Harm to Competition}

A reduction in the number of hospitals in a market may allow the remaining hospitals to cooperate in a price increase for all or most services. ${ }^{114}$ Collusion is the primary harm to competition that could result from horizontal ${ }^{115}$ hospital mergers, and thus the primary concern of their antitrust review. Cooperation need not take the form of an explicit contract; a tacit agreement to raise prices among firms aware of each other's marketplace behavior equally generates antitrust concern. 116

Joint ventures among horizontal competitors raise anticompetitive concerns similar to those of horizontal acquisitions and are subject to a similar antitrust review. ${ }^{117}$ Hospital management contracts ${ }^{118}$ in effect create joint ventures among the hospitals with affiliated managements. Thus, an agreement by one hospital to be managed by the same firm that owns or manages a competitor will be subject to antitrust review because it may facilitate hospital industry collusion much as could a merger between the hospitals. 119

The DOJ Guidelines treat the number of firms in the industry as an important indicator of the likelihood of collusion, because it becomes more difficult to coordinate and police cartels as their membership increases. ${ }^{120}$ In

114. Cf. id. $\S 1$ ("Where only a few firms account for most of the sales of a product, those firms can in some circumstances either explicitly or implicitly coordinate their actions in order to approximate the performance of a monopolist.")

115. Horizontally related firms sell goods or services in direct competition. Firms are vertically related to their suppliers and customers. Mergers involving unrelated firms are termed conglomerate mergers. Although many if not most mergers involving hospitals are not horizontal, this article emphasizes the analysis of horizontal hospital mergers because they are the primary concern of antitrust enforcers today. Cf. Rule, Antitrust Enforcement and Hospital Mergers: Safeguarding Emerging Price Competition, 21 J. HEalth AND Hosp. L. 125, 125 (1988) (Antitrust Division does not investigate the acquisition by a multihospital chain of a hospital in a geographic market in which the system currently does not do business); but see infra notes $136-38$ and accompanying text.

116. See, e.g., United States v. General Motors Co., 384 U.S. 127, 142-43 (1966); Esco Corp. v. United States, 340 F.2d 1000, 1007-08 (9th Cir. 1965); ff. R. Posner, supra note 37, at 39-77 (antitrust law should reach express and tacit collusion, but not mere oligopolistic interdependence).

117. United States v. Penn-Olin Chem. Co., 378 U.S. 158 (1964); see General Motors Corp., 103 F.T.C. 374 (1984) (approving GM-Toyota joint venture); see generally Bresnahan \& Salop, Quantifying the Competitive Effects of Production Joint lentures, 4 InT'L J. Indus. ORG. 155 (1986). Research and development joint ventures are analyzed under a lenient statutory standard. 15 U.S.C.A. $§ 4301-05$ (West Supp. 1988) (National Cooperative Research Act of 1984).

118. See supra notes 32-33 and accompanying text (multihospital systems); infra notes 273-74 and accompanying text (concentration measures).

119. Firms entering into hospital management contracts are not subject to pre-merger notification, however, unless the agreements also involve the acquisition of stock or assets. 15 U.S.C. $\$ 18$ a (1982) (Hart-Scott-Rodino Amendments to the Clayton Act).

As with mergers, hospital management contracts may create production efficiencies and thereby lower consumer prices rather than generate anticompetitive price increases. For example, the managed hospital may take advantage of superior management talent, or scale economies in purchasing, hiring, and other functions. The antitrust significance of efficiencies from mergers or joint ventures is discussed infra notes $337-46$ and accompanying text.

120. 1984 Merger Guidelines, supra note 51, \$ 3.1; see generally Elzinga, New Developments on the Carlel Fromt, 29 Antitrust Bull. 3 (1984); Stigler, A Theory of Oligopoly, 72 J. Pol. Econ. 44 (1964). The Department of Justice's choice of concentration index, the HHI, can be interpreted as measuring the number of equal sized firm equivalents to the current market structure. (The number of equal sized firm equivalents is determined by dividing 10,000 by the $\mathrm{HHI}$. Thus, an $\mathrm{HHI}$ of 2000 
general, the greater the number of colluding firms, the more difficult it is for them to agree how to allocate among themselves the output reduction necessary to engineer a desired price rise. ${ }^{121}$ Sellers find coordination particularly difficult because an express agreement to fix prices and reduce output is unenforceable, as it violates Sherman Act section 1. ${ }^{122}$

Furthermore, the greater the number of firms involved, the more difficult it is for firms to enforce a cartel. Every member of a cartel has an incentive to cheat on the agreement: A firm can profit by secretly undercutting the cartel price by a small amount, preserving a price well above marginal cost while dramatically increasing output. This incentive to cheat disappears, however, when rivals quickly detect a cheater's output expansion and are able to punish it by expanding output speedily to reduce the market price. If this response can be anticipated, a potential cheater will recognize that it will be unable to sell many additional units at the high cartel price. Under such circumstances, cartel members will find cheating less profitable than cooperating. ${ }^{123}$ In general, the fewer the firms, the easier monitoring and policing cheating from a collusive agreement becomes, and thus the greater the danger that attempts to collude will be successful. ${ }^{124}$

The regulatory framework presently governing hospitals may affect the form through which the private benefits from collusion become manifest. To the extent that prospective payment regulation caps the rates hospitals may charge, ${ }^{125}$ colluding hospitals will be unable to obtain higher prices directly through cooperation. ${ }^{126}$ Hospitals subject to binding maximum price regulation may nevertheless raise price indirectly, through concerted action to reduce quality of care. ${ }^{127}$ For example, hospitals would profit from concerted action to reduce the frequency of tests given patients with various diagnoses, or concerted action to reduce amenities for doctors or patients. ${ }^{28}$ Similarly,

could have been generated by five equally sized firms, and an HHI of 1000 could have been generated by ten equally sized producers.) In this way, the Guidelines are concerned with both the relative size of competitors and their number.

121. When sellers as a group reduce output, the market price rises because consumers will bid up the purchase price along the downward sloping market demand curve.

122. 15 U.S.C. $\$ 1$ (1982).

123. See generally Salop, supra note 45.

124. For a discussion of other factors that facilitate or hinder collusion, see infra notes 305-35 and accompanying text.

125. In most states prospective payment caps presently apply only to patients covered by Medicare. It is also possible that hospitals have set rates below these maximums.

126. However, there are many ways hospitals can collude on price, or, similarly, collude to reduce advertising and promotional expenses. See generally Hospital Corp. of Am., 106 F.T.C. 36 1, 496-99 (1985).

127. Such a scheme in effect raises prices when they are expressed in units of constant quality. Thus, it has the same economic effect as collusion over price. See id at 497 (examples of how colluding hospitals might reduce quality competition).

128. If hospital quality would be inefficiently high in the absence of cooperation because of the market failures discussed previously, a hospital cartel that lowers quality might improve economic efficiency. However, it would be difficult to tell whether this would occur in any specific case. Further, Congress has arguably dismissed this possibility by authorizing states to set up CON procedures and peer-review mechanisms to monitor expenses, without exempting hospital mergers from the usual antitrust review. Had Congress believed that hospital competition would reduce 
hospitals may coordinate to resist cost containment pressures created by insurers $^{129}$ or PPO's, ${ }^{130}$ or to manipulate certificate-of-need processes to reduce entry. ${ }^{131}$

Collusion among the horizontal competitors that sell in a relevant market is in practice the primary concern of antitrust enforcers and courts in analyzing prospective mergers. However, mergers can also lead to anticompetitive consequences through other mechanisms. These mechanisms, noted below, are not discussed in detail because they do not yet appear in the hospital merger case law.

First, a reduction in the number of firms in a market through merger can cause the price charged by non-cooperating oligopolists to increase even if the firms do not collude, merely because the competing firms are few enough to recognize their interdependence. The resulting price increases are likely to be small if sellers deal in homogeneous products; tacit collusion rather than a change in the non-cooperative oligopoly equilibrium is properly the central focus of merger enforcers when goods are not differentiated. ${ }^{132}$

If instead producers offer significantly differentiated products or services, as may be true with hospitals, ${ }^{133}$ cooperation between as few as two producers

social welfare, as with natural monopolies, it could have mandated traditional rate of return regulation. See generally S. Breyer, Regulation ANd Its Reform (1982).

If regulatory policy concerning hospitals were to move to utility style rate-of-return regulation, hospitals could be required to separate regulated and unregulated activities in separate subsidiaries and avoid mergers that would evade rate regulation. See 1984 Merger Guidelines, supra note 51 , $\S 4.23$; United States v. American Tel. \& Tel. Co., 524 F. Supp. 1336 (D.D.C. 1981) (denying defendants' motion to dismiss), 552 F. Supp. 131 (D.D.C. 1982) (modified final judgment, approving proposed decree ordering a regulated utility company, inter alia. to divest local operating companies and requiring equal access to certain facilities), aff $d \mathrm{mem}$. sub nom. Maryland v. United States, 460 U.S. 1001 (1983). The concern for evasion of rate regulation is absent when the regulatory scheme limits entry without regulating prices

129. See generally Hospital Corp. of Am., 106 F.T.C. at 496. Concerted boycotts of insurers could lead to higher prices directly, by removing a competitive force pressuring for price discounts, or indirectly through reduced quality of service.

130. PPO's may obtain low cost hospital services for those patients who obtain health care through them by seeking competitive offers of discounts from hospitals. Through coordinated pricing, hospitals may resist this competitive pressure.

131. Hospital Corp. of Am., 104 F.T.C. at 498. Rival hospitals earning economic profits have an incentive to agree to protest a certificate-of-need application made by a potential entrant. To the extent incumbent hospital views are influential to the board awarding certificates of need, or to the extent a contested certificate of need is expensive for an applicant to pursue, then entry will be deterred or delayed, and incumbent hospitals will protect their economic profits from new competition. While the hospitals acting collectively to deter entry may be earning the profits they are protecting from a collusive agreement to raise price or lower quality of care, these profits are not necessarily predicated on cooperation outside of the agreement to protest the certificate of need. For example, if demand grows in a geographic market, incumbent hospitals recognizing their interdependence but not cooperating may choose prices under which each earns economic profits. But see infra note 132 and accompanying text (gains from noncooperative interaction may be small). Economic profits will remain so long as the hospitals deter both new entry and incumbent hospital expansion, both of which could require a certificate of need.

132. See Ordover, Sykes \& Willig, Herfindahl Concentration, Rivalry, and Mergers, 95 HARv. L. REv. 1857 (1982); Horizontal. Mergers, supra note 35, at 179-80; R. Posner, supra note 37, at 39-77 (antitrust law should reach express and tacit collusion, but not mere oligopolistic interdependence).

133. Quality differences among hospitals in one metropolitan area are extremely large. Hospitals, 6 Washington Consumers' Checkbook I3 (1987). 
of similar products can lead to large economic profits even if the other firms in the relevant market do not participate in the cooperative arrangement. This will occur if, for a substantial fraction of consumers, the two firms' products are close substitutes, while no third firm offers another product that buyers would readily substitute for these goods. ${ }^{134}$ Although this possibility is relevant to antitrust merger analysis, ${ }^{135}$ it has not been raised in the handful of extant hospital merger opinions.

Mergers or joint ventures between hospitals and non-hospital entities can have anticompetitive effects through another non-collusive mechanism: A merger might raise rivals' costs, and thereby enable the merger partners to raise price. ${ }^{136}$ For example, a merger between a hospital and an equipment supplier could raise costs for rival hospitals if it forecloses their access to low cost inputs. Alternatively, the merger could raise costs for rival suppliers if it forecloses their ability to sell to the hospital. In either case, the merger would have anticompetitive consequences if the lessening of competition from disfavored rivals enables the merging firms to raise price, either for hospital services or for hospital supplies. ${ }^{137}$ As with horizontal mergers, these

134. Suppose, for example, that three neighboring hospitals offer coronary bypass surgery, but one of the three is substantally disfavored by consumers relative to the others because it has a higher mortality rate for the operation or lacks a new diagnostic tool (product differentiation), or because it is in an inconvenient location relative to the others (geographic differentiation). In such a case, a merger between the first two hospitals could lead to higher rates for this operation. Under current enforcement agency and judicial practice, it is unlikely that the product market would exclude the third, disfavored firm. An antitrust analysis would nevertheless take this effect into account by treating a reduction in direct competition as a potential competitive concern in a broad market. See infra note 135 .

135. See 1984 Merger Guidelines, supra note 51, § 3.413; Complaint, Federal Trade Commission v. Coca-Cola Co., No. 86-1764 14(a) (D.D.C. filed June 24, 1986) (proposed merger alleged likely to lessen competition by eliminating direct competition between Coca-Cola and Dr. Pepper); Baker \& Bresnahan, The Gains from Merger or Collusion in Product-Differentiated Industries, $33 \mathrm{~J}$. InDus. ECON. 427 (1985).

A court concerned about this competitive problem could address it by defining significantly more narrow product markets in differentiated product industries than are currently employed. However, it is unlikely that an antitrust enforcer or court in the present environment would group, for example, Coca-Cola and Dr. Pepper in a product market to the exclusion of Pepsi even were cooperation from Dr. Pepper alone likely to allow Coke to raise prices significantly. Compare Federal Trade Commission v. Coca-Cola Co., 64l F. Supp. 1128, 1133 (D.D.C. 1986) (carbonated soft drink product market), vacated, 829 F.2d 191 (D.C. Cir. 1987), with M. Reinstadtler, The Economics of Merger In Product Differentiated Industries: A Framework for Analyzing Merger Activity in the Soft Drink Industry, (Master's Thesis, Sloan School of Management, Massachusetts Institute of Technology, May 1987) (Coca-Cola would gain market power by merging with Dr. Pepper), and Complaint, Federal Trade Commission v. Coca-Cola Co., No. 86- 764 I 14(a) (D.D.C. filed June 24, 1986) (merger would remove direct competition between Coca-Cola and Dr. Pepper).

136. See Complaint, Federal Trade Commission v. Coca-Cola Co., No. 86-1764 9 14(d) (D.D.C. filed June 24, 1986) (merger allegedly created market power by raising rival's costs); $c f$. Christian Schmidt Brewing Co. v. G. Heileman Brewing Co., 753 F.2d. 1354 (6th Cir.) (competitor has standing to challenge merger because acquisition allegedly harms competitor's access to distribution), cert. dismissed, 469 U.S. 1200 (1985).

137. These are vertical mergers with horizontal consequences. In each case, the merging firms in effect create an "involuntary cartel;" rivals facing an increase in marginal costs are forced to reduce output much as they would were they party to a collusive agreement with the merging firms. See generally references cited supra note 45.

Similarly, a joint venture between a hospital and health care providers such as HMO's or PPO's could raise costs for competing hospitals by foreclosing them from patients or medical staff. See 
possible anticompetitive harms from vertical acquisitions must be weighed against any efficiency benefits of vertical integration before the merger is proscribed. ${ }^{138}$

\section{B. Market Definition}

To analyze whether a hospital merger increases the likelihood of collusion among the firms remaining in a market, the enforcement agencies and courts first define the markets of interest. ${ }^{139}$ Market definition is often the determinative analytic step in antitrust litigation, and thus is strongly contested. 140 The primary market definition approach employed today is expressed in the DOJ Guidelines. ${ }^{141}$ The DOJ Guidelines define a relevant

generally Baker, supra note 32. However, the efficiency gains from vertical coordination will generally overwhelm any competitive harm arising from such an arrangement.

138. See infra notes 338-46 and accompanying text (efficiency defense). Vertical integration may generate a host of possible efficiencies. Kaserman, Theories of Vertical Integration: Implications for Antitrust Policy, 23 Antitrust Bull. 483 (1978); Waterson, Vertical Integration, Variable Proportions and Oligopoly, 92 Econ. J. 129 (1982); Williamson, The Vertical Integration of Production: Market Failure Considerations, 61 Am. Econ. Rev. 112 (Papers \& Proceedings 1971).

139. This approach is employed regardless of whether firms would seek to cooperate in order to raise prices or to lower quality of care. See supra note 31 and accompanying text, notes 127-28 and accompanying text (lowering quality is like raising price).

140. An amusing account of this process appears in Stigler. The Economists and the Problem of Monopoly, in The Economist as Preacher and Other Essays 38, 51 (G. Stigler ed. 1982).

To the extent antitrust enforcers emphasize the economic consequences of a transaction rather than identifying its legal categories, market definition is less determinative of the judicial outcome. For example, an industry with one group of firms selling close substitutes and another group selling more distant substitutes could be viewed in antitrust terms alternatively as two narrowly defined markets where each group of firms offers significant potential competition for the other, or as one broadly defined market in which some firms sell goods differentiated from the output of others. It is difficult to see why the legal consequences of a merger among two firms selling close substitutes in this industry should turn on the arbitrary choice between these two views of the market, even though the increase in market concentration is likely to appear much larger if the narrower market definition is adopted.

141. I982 Merger Guidelines, supra note 5l. This approach was preserved with minor modifications in the 1984 revisions to the DOJ Guidelines. So long as economic efficiency remains an important goal of antitrust enforcement, the DOJ Guidelines market-definition algorithm is likely to remain the leading market-definition methodology, as it defines markets with express reference to interdicting the exercise of market power in the economist's sense of the term. 1984 Mercer Guidelines, supra note 51, §§ 1, 2. See generally Horizontal Mergers, supra note 35, at 105-110 (description of "hypothetical monopolist" market definition paradigm).

Two alternative paradigms continue to have advocates, though each has been criticized by adherents of the DOJ Guidelines approach. The first defines market boundaries based on the absence of product flows. Elzinga \& Hogarty, The Problem of Geographic Market Delineation in Antimerger Suits, 18 AnTitrust Bull. 45 (1973); Elizinga \& Hogarty, The Problem of Geographic Market Delineation Revisited: The Case of Coal, 23 AntrTrust BuLl. 1 (1978); see Harris \& Jorde, Antitrust Market Defnition: An Integrated Approach, 72 CALIF. L. REV. 1 (1984) (analogous approach to product market definition); see generally Horizontal Mercers, supra note 35, at 96-10I (description and evaluation of "historical insularity" as a market definition paradigm); but see Werden, The Use and Misuse of Shipments Data in Defining Geographic Markets, 26 ANTITRust Bull. 719 (1981) (critical evaluation of product flow approach to geographic market definition by one drafter of $1982 \mathrm{DOJ}$ Guidelines).

A second alternative paradigm includes goods with correlated prices in the same market. Stigler \& Sherwin, The Extenl of the Market, 28 J. L. \& ECon. 555 (1985); Horowitz, Market Definition in Antitrust Analysis: A Regression-Based Approach, 48 S. ECON. J. 1 (1981); see generally Horizontal Mergers, supra note 35, at 102-105 (description and evaluation of "price relationships" paradigm); but see J. BAKER, Why Price Correlations Do Not Define Antitrust Markets: On Econometric Algorithms for Market Definition (Working Paper No. 149, FTC Bureau of Economics 1987) (critical evaluation of 
market as a set of products within a geographic area that could profitably be sold at a significantly higher price (for example, a 5 percent price increase) were their sellers to coordinate pricing and output decisions. ${ }^{142}$ This algorithm relies on projecting the profitability of a price increase to what the DOJ Guidelines term a hypothetical "monopolist" of the products at issue. These sellers might equivalently be viewed as a hypothetical cartel. ${ }^{143}$

\section{Demand and Supply Substitutability. The DOJ Guidelines emphasize that} two economic forces might defeat the attempt of a hypothetical cartel to raise price through a coordinated reduction in output among cartel members. The first is demand substitutability: consumers may respond to a high cartel price by switching to goods not included in the hypothetical cartel, or by doing without the cartelized product altogether, in sufficient numbers as to make the price rise unprofitable. ${ }^{144}$ The second force that might impede the hypothetical cartel from successfully raising price is supply substitutability: firms not included in the hypothetical cartel, or potential entrants, may be able to produce profitably a product competitive with the good sold by the hypothetical cartel while undercutting the cartel's price. If so, consumers may switch to the new product in sufficient numbers to make the hypothetical cartel's price increase unprofitable. ${ }^{145}$ In assessing both demand and supply substitutability, the appropriate factual inquiry is a hypothetical one. It is necessary to look beyond actual substitution patterns to the potential substitution likely to follow a hypothetical 5 percent price rise. ${ }^{146}$

price correlations approach to market definition); Scheffman \& Spiller, Geographic Market Definition Under the U.S. Depariment of Justice Merger Guidelines, 30 J. L. \& Econ. 123, 124-28 (1987) (comparing "economic markets" defined by price correlations with "antitrust markets" defined in accordance with the DOJ Guidelines)

142. 1984 Merger Guidelines, supra note $51, \S 2$. The DOJ Guidelines can be understood as defining a relevant market as a group of homogeneous products sold in a region such that the collectivity faces a downward sloping residual demand curve, under the frequently plausible assumption that the hypothetical cartel has roughly constant marginal costs for outputs between the competitive and the cartel levels. See generally Landes \& Posner, Market Power in Antitrust Cases, 94 HARv. L. Rev. 937 (1981); Scheffman \& Spiller, supra note 141, at 124-28; J. BAKER, supra note 141; cf. Baker \& Bresnahan, The Gains from Merger or Collusion in Product-Differentiated Industries, 33 J. INDUS. ECON. 427 (1985) (technique for estimating residual demand curve); Baker \& Bresnahan, Estimating the Residual Demand Curve Facing a Single Firm, 6 Int'l J. Indus. Organization 283 (1988) (same); Harris \& Simons, Focusing Market Definition: How Much Substitution is Necessary?, in RESEARCH IN L. \& ECON. (R. Zerbe ed.) (forthcoming) (identifying percentage sales loss necessary to make a price rise unprofitable). Concentration and factors facilitating or frustrating collusion are important because they influence the ability or interest of the firms in the collectivity to take advantage of the group's downward sloping demand curve.

143. 1984 Merger Guidelines, supra note 51 , $\$ 2$.

144. For an analysis of how much sales the hypothetical cartel must lose before raising price becomes unprofitable, see Harris \& Simons, supra note 142.

145. A third force might defeat an actual cartel: cheating on the cartel price by cartel members. However, the conceptual experiment for market definition of the DOJ Guidelines presumes that cartel coordination is perfect and asks whether that hypothetical coordination would be profitable. Once a market is defined according to this approach, the remainder of the Guidelines analysis addresses whether coordination is likely within that market by considering concentration, entry conditions, and other factors affecting the incentives of market participants to collude or to cheat on a cartel. See generally infra notes $183-87$ and accompanying text.

146. For many products, market demand may grow more elastic as price rises. If so, a smaller fraction of customers will substitute away from the good when price rises from a low level, relative to 
In principle, an extremely large number of relevant markets that include the merger partners will satisfy the DOJ Guidelines definition. ${ }^{147}$ However, as the DOJ Guidelines note, in most antitrust cases it will be sufficient to analyze the transaction in the smallest market satisfying the market definition algorithm. ${ }^{148}$ Such parsimony is not uniformly practiced in the antitrust analysis of hospital mergers, however, as will become evident in the discussion of the "cluster market" approach to product market definition.

\section{Product Market Definition: Application of the DOJ Guidelines to Hospitals. The} substitutability analysis of the DOJ Guidelines readily applies to hospital product market definition. The procedure begins with each hospital service offered by the merging hospitals, such as childbirths, emergency room treatment, or heart surgery. ${ }^{149}$ To determine the extent of demand substitutability for each service, a question like the following must be posed: If the price of a medical service rises by 5 percent for one year, will a sufficient fraction of patients forgo the use of that service or substitute some other form of treatment to make that increase unprofitable? ${ }^{150}$ Patients may make this

the fraction who will shift away if price rises the same percentage from a higher base. This likely empirical regularity, termed the "Cellophane trap" in antitrust analysis, leads to the seeming paradox that greater demand substitution may be observed when a good sells for a monopoly price than when it sells for a competitive price. See Note, The Cellophane Fallacy and the Justice Department's Guidelines for Horizontal Mergers, 94 YALE L.J. 670 (1985).

147. For example, suppose that all the cola-flavored soft drinks constitute a product market because consumers would accept a significant price rise coordinated among the cola brands produced by Coke, Pepsi, RC, and other manufacturers, without switching to other soft drink flavors such as lemon-lime or root beer. Then, necessarily, all soft drinks, all beverages, and all food products, for example, will also constitute product markets, because coordinated action by all producers of these goods could at a minimum lead to an increase in the price of soft drinks, and may lead to higher prices for other goods as well. Similarly, if three neigboring states comprise a relevant geographic market for the sale of some product, because a price increase limited to those states would not be competed away by consumers shopping outside the area or by outside dealers shipping a competitive product into the area, then other relevant geographic markets can always be defined by adding additional states to the original three.

One might wish to analyze a merger in one of these broader markets as well as in the smallest market that satisfies the DOJ Guidelines algorithm because anticompetitive behavior may be more likely to occur in markets in which it is more attractive. If the gains from collusion are limited in a narrow market (for example, because market demand is fairly elastic) while those gains are large in a broad market (because demand is inelastic), and if the broad market incorporates few if any more producers than the narrow market, then the danger from both collusion and its likelihood may be greater in the broad market. See Weverhaeuser Co., 106 F.T.C. 172, 289-90 (1985) (geographic market excludes distant producers who nevertheless "limit the amount of harm [from] . . . any exercise of market power"). Another example of a merger more troublesome in a broad market than a narrow one appears infra note 204 (transactions complements). Furthermore, some mergers may produce anticompetitive effects in markets in which the merging firms do not directly participate. See FTC v. Coca-Cola Co., 641 F. Supp. 1128 (D.D.C. 1986) (merger of upstream soft drink concentrate producers has anticompetitive effect in downstream soft drink market), vacated, 829 F.2d 191 (D.C. Cir. 1987).

148. 1984 Merger Guidelines, supra note $51, \S \S 2.11,2.31$.

149. Each of these services could be viewed as the aggregation of more finely parsed services. In the event there are significant limitations on demand and supply substitutability within these groupings, the product mark t definition procedure should commence at a more disaggregated level, perhaps with services such as normal childbirths, poisoning emergencies, or coronary bypass surgery.

150. The DOJ Guidelines ask whether sellers could profitably impose a "small but significant and nontransitory" price increase. In most contexts, the Department interprets this phrase as indicating 
decision on their own, their doctor may make it for them, or insurers may influence patient decisions by refusing reimbursement for all or part of the inflated charges.

If few patients will substitute some other treatment or forgo use of the medical service in response to a 5 percent price rise, so that the price increase would be profitable for a hypothetical monopolist of the service, then demand substitutability will not limit the ability of a hypothetical monopolist to exercise market power. Hence, the service at issue constitutes a product market under the Guidelines, unless the market must be expanded to account for supply substitutability. If, instead, the price rise would be unprofitable when limited to a service or a set of services, additional services must be added to the proposed product market from those other treatments patients would substitute for it until a set of services satisfying the demand substitutability test is identified.

To determine the extent of supply substitutability for a service offered by one of the merging hospitals, a similar question must be posed: If the hospital raises prices for the service and its demand substitutes by 5 percent, in combination with those other institutions also offering any of the services in that set, will rival institutions currently or potentially offering other hospital services be able to introduce the cartelized services within one year, and thus compete away the hypothetical price increase? ${ }^{151}$ If production flexibility would limit the ability of a hypothetical cartel to raise price profitably, the product market must be expanded to account for the competitive influence of firms selling supply substitutes. ${ }^{152}$

The DOJ Guidelines approach emphasizes that different competitors may be found in each product market in which the merging firms participate. For large classes of hospital services, such as many types of secondary inpatient care, ${ }^{153}$ the same firms-namely all the local hospitals-will likely be found in

a $5 \%$ price rise lasting one year. 1984 Merger Guidel.ines, supra note $51, \S 2.11$. The Department of Justice may presently employ a $10 \%$ price rise rather than a $5 \%$ price rise as its standard in market definition. Briggs, An Overinew of Current Law and Policy Relating to Mergers and Acquisitions, 56 ANTRUST L.J. 657, $681 \mathrm{n} .1$ (1988). A 10\% standard should tend to broaden product markets, although it is difficult to gauge the practical significance of this change.

151. 1984 Merger Guidelines, supra note $51, \S 2.21$.

152. It may be difficult to identify the amount of sales or capacity of firms producing supply substitutes that must be included in the market share computation. See infra notes 267-72 and accompanying text (units in which concentration is measured); 1984 Merger Guidelines, supra note 51 , \$ 2.21 n.10 (1984); see generally Horizontal Mergers, supra note 35, at 110-16.

153. Nearly all hospitals offer "primary" or outpatient care, as may a variety of non-hospital health care providers including family practioners, physicians' offices, outpatient clinics, and perhaps chiropractors. "Secondary" care is provided by most, although not all, hospitals. This category involves the commomly requested services of specialists in areas such as surgery, radiology, anesthesiology, obstetrics, and pediatrics. Some non-hospital institutions, such as surgi-centers, may offer some forms of secondary care. Basic nursing, medical, surgical, anesthesiology, laboratory, radiology, pharmacy, and dietary hospital services are sometimes considered primary care, and other times considered secondary care. "Tertiary" care involves complex and specialized treatments, such as complex surgery or the treatment of severe illnesses. It is usually provided by teaching hospitals in large urban areas. The distinctions among these service groupings are fluid, but generally turn on the frequency of patient utilization (tertiary care services are the least frequently required), the number of hospitals offering the service (tertiary care services are least frequently offered, most likely 
each relevant product market. ${ }^{154}$ However, for some services, the product market will include such new institutions as free standing ambulatory care facilities or free standing surgical care facilities.

When product markets for hospital services are defined by the DOJ Guidelines approach, supply substitutability is likely to be the most contested issue in product market definition. Patients in need of one medical procedure will rarely be able to substitute another; demand substitutability will generally be limited. In contrast, it is possible that hospitals can easily shift resources across vastly different services. If, for example, hospitals offering appendectomies, but not coronary bypass surgery, could quickly and cheaply shift equipment, facilities, and personnel to offer the cardiac procedure, then the two services should be incorporated into the same product market on supply substitutability grounds. ${ }^{155}$ Even if supply substitutability is substantial, the market definition approach of the DOJ Guidelines is likely to generate a large number of relevant product markets in which a merger must be evaluated. It is unlikely that all hospital services are supply substitutes, however. ${ }^{156}$

3. Product Market Definition: Cluster Markets. The reported hospital merger decisions employ an approach to product market definition that relies on the Supreme Court's "cluster of services" paradigm. The first cluster market was defined by the Court in its 1963 decision in United States v. Philadelphia National Bank. ${ }^{157}$ In that case, the Court determined that commercial banking

because few physicians can acquire sufficient experience to become competent providers when few patients require the services), and the complexity of the service (tertiary care services are the most complex). Tertiary care services are generally, if not always, provided by institutions also offering secondary care. See Proger, Relevant Market, 55 Antitrust L.J. 599, 616 (1987).

154. For this reason, cluster markets probably are not inconsistent with the DOJ Guidelines methodology. See infra notes $184-201$ and accompanying text (pragmatic approach).

155. Some aspects of the two procedures appear to overlap: Both may require the use of some of the same diagnostic instruments, the same operating rooms and hospital beds, and the same nursing staff. However, a hospital performing one procedure may lack surgeons and specialists experienced in the other procedure, and may not own some diagnostic and treatment tools. Furthermore, it may take time to develop a reputation among referring physicians and patients for quality care in the new medical practice area. If the hospital is unable to remedy these and any other omissions within one year, the time horizon of the DOJ Guidelines for market definition, then the two procedures should not be placed in the same market on supply substitutability grounds. In addition, if hospitals must obtain regulatory approval to offer new services, such as certificate-of-need approval to create additional facilities, and if the regulatory process is time-consuming, supply substitution possibilities will be further reduced. Cf. infra notes 290-97 and accompanying text (discussion of certificate of need as entry barrier).

156. One commentator contends that all types of medical services, such as medical-surgical, pediatrics, obstetrics, and gynecology are close substitutes in supply, and concludes that acute inpatient care forms a relevant product under the substitutability criteria of the DOJ Guidelines. Lynk, Antitrust Analysis and Hospital Certificate-of-Need Policy, 32 Antrrrust Bull. 61,74 (1987). This author offers no evidence for the claimed production flexibility and ignores the difficulties discussed supra in note 155 that impede a primary care hospital or limited secondary care facility considering the addition of secondary or teritary care services. See also infra note 167.

157. 374 U.S. $321,356-57$ (1963); accord United States v. Connecticut Nat'l Bank, 418 U.S. 656 , 664-66 (1974); United States v. Phillipsburg Nat'l Bank \& Trust Co., 399 U.S. 350, 360-61 (1970); cf. United States v. Grinnell Corp., 384 U.S. 563, 573 (1966) (defining cluster market of central station protective services). 
activity-including loans and other types of credit, deposit accounts, checking services, and trust administration-formed a unique cluster of products and services distinct from those offered by other financial institutions such as savings and loans, finance companies, and credit unions.

The Court has provided little theoretical justification for grouping products or services into the one product market. Banking services were clustered in Philadelphia National Bank because distinctiveness, cost advantages, and "a settled consumer preference" insulated each commercial banking product from competition. ${ }^{158}$ In contrast with all previous product markets defined by the Court, the goods and services clustered into the commercial banking product market were neither demand nor supply substitutes. ${ }^{159}$ Although the Supreme Court has not defined a cluster market since 1974, it has never renounced the approach. In consequence, lower courts continue to apply the cluster market concept to exclude firms supplying partial product lines from product markets when some producers supply a full line. ${ }^{160}$

The cluster market concept is to date the uniform approach to product market definition of the hospital merger case law. ${ }^{161}$ Relying on the cluster of

158. 374 U.S. at 356-57. Outside of banking services, the Court has identified only one product market termed a cluster of services, for accredited central station protective services. United States v. Grinnell Corp., 384 U.S. at 573. This cluster was justified on the view that "to compete effectively, [firms] must offer all or nearly all types of service." Id. at 572. Further, in both Philadephia Nai'l Bank and Grimell, the Court found "commercial realities" consistent with the cluster. 374 U.S. at 357; 384 U.S. at 572. In Grinnell, decided under Sherman Act $\$ 2$, the Court also established that the cluster approach is not limited to market definition under the Clayton Act, the statute enforced in Philadelphia Nat'l Bank.

159. The goods and services "viewed collectively [have] . . characteristics which negate reasonable interchangeability." United States v. Philadalphia Nat'l Bank, 201 F. Supp. 348, 363 (E.D. Pa. 1962), rev'd on other grounds, 374 U.S. 321 (1963). While neither the district court nor the Supreme Court investigated the possibility of supply substitutability in its market definition analysis, the opportunities for production flexibility appear limited in the banking industry. For example, the resources devoted to trust administration are probably not well suited for making commercial loans or accepting demand deposits. In contrast, the protective services clustered in Grinnell, including burglary and fire protection when offered electronically from a central station, are likely supply substitutes although they are not demand substitutes. See 384 U.S. at 572-73. Thus, Grinnell, unlike the bank cases, may be understood as reflecting the supply substitution principle in market definition. See supra note $41 ;$ f. 1984 Merger Guidelines, supra note $51, \S 2.21$ n.9 (production substitution may lead to aggregate description of markets).

160. The commercial banking product cluster excludes financial intermediaries such as credit unions and savings and loans that offer some but not all banking services. See Horizontal Mergers, supra note 35 , at 75-76, 75 n.370 (collecting lower court decisions excluding partial line producers from cluster markets); but of. United States v. Phillipsburg Nat'l Bank, 399 U.S. 350, 360-61 (1970) (other financial institutions do not provide the convenient customer access to financial services offered by banks, hence do not offer close substitutes for any bank services). In banking cases, lower courts arguably remain constrained by precedent to adopt the cluster market approach even when substitutability considerations might suggest alternative product market definitions. See Note, The Line of Commerce for Commercial Bank Mergers: A Product-Oriented Redefinition, 96 HARv. L. REv. 907,912 n.32 (1983); United States v. Connecticut Nat'l Bank, 418 U.S. 656, 663-64 (1974) (similarity between savings and commercial banks "is not sufficient at this stage in the development of savings banks... to treat them together with commercial banks").

161. However, courts have generally ignored the cluster market concept in defining product markets in recent non-merger cases involving medical services provided by hospitals. E.g., Jefferson Parish Hosp. Dist. No. 2 v. Hyde, 466 U.S. 2 (1984) (anesthesiology services constitute a product separate from other hospital services) (tying claim); Seidenstein v. National Medical Enter., 769 F.2d 
services paradigm, product markets have been defined consisting of "general acute care hospital services," excluding outpatient substitutes for the individual services comprising the cluster; ${ }^{162}$ "short term, acute care hospital services;" 163 "inpatient psychiatric care by private psychiatric hospitals and non-government general acute care hospitals;" 164 "acute inpatient hospital care;" 165 and inpatient hospital services including outpatient substitutes for those services. ${ }^{166}$ As with the markets defined in the Supreme Court's bank cases, these product markets include services that are neither demand nor supply substitutes. ${ }^{167}$

The cluster approach raises a variety of analytic and practical difficulties. From the substitutability perspective of the DOJ Guidelines, the approach is remarkable because it asserts antitrust relevance to collections of products and services that are not substitutes. ${ }^{168}$ Furthermore, the weak theoretical basis for the groupings defined by the Court makes it difficult for lower courts to identify other appropriate collections of non-substitutes in a principled way.

The cluster approach is also troublesome in application. It appears likely to lead government enforcers and courts to apply the antitrust laws in a manner inconsistent with promoting economic efficiency in two situations, when both of these difficulties may be avoided by defining product markets for individual services pursuant to the DOJ Guidelines. First, the cluster

1100 (5th Cir. 1985) (invasive cardiology services market) (monopolization claim); Robinson v. Magovern, 521 F. Supp. 842, 878 (W.D. Pa.) (adult open heart surgery market) (refusal to deal and monopolization claims), aff'd, 688 F.2d 824 (2d Cir.), cert. denied, 459 U.S. 971 (1982); Gonzales v. Insignares, 1985 Trade Cas. (CCH) I 66,701 (N.D. Ga. 1985) (anesthesiology market and medical services market) (exclusive dealing claim); but see Weiss v. York Hosp., 745 F.2d 786, 826-27 (3d Cir.) (upholding jury finding of inpatient hospital health care cluster market) (monopolization claim), cert. denied, 470 U.S. 1060 (1985).

162. Hospital Corp. of Am., 106 F.T.C. at 466; (quoting American Medical Int'l, 104 F.T.C. at 192-94; see United States v. National Medical Enter., 1987-1 Trade Cas. (CCH) I 67,640 (E.D. Cal. 1987) (general acute care hospital services product market) (consent judgement).

163. American Medicorp, Inc. v. Humana, Inc., 445 F. Supp 589, 605 (E.D. Pa. 1977)

164. United States v. Hospital Affiliates Int'l, 1980-81 Trade Cas. (CCH) ף 63,721, at 77,852-53 (1980) (preliminary injunction case). Government hospitals were excluded because they offered a different quality of care than private psychiatric hospitals.

165. United States v. Rockford Memorial Corp., No. 88-C-20186, slip op. at 23 (N.D. Ill. Feb. 23, 1989), appeal filed.

166. United States v. Carilion Health System, 707 F. Supp. 840, 849 (W.D. Va. 1989) (order denying injunction), appeal filed, No. 89-2625 (4th Cir. 1989).

167. One commentator contends that an acute inpatient hospital care cluster is justified by strong supply substitutability in the provision of hospital services. Lynk, supra note 156 , at 74 . This view implictly rejects the narrower product market definitions common in non-merger antitrust litigation involving hospital services, see supra note 163, and implicitly suggests that the inpatient hospital product market clusters identified in merger litigation follow from Grinnell rather than from Philadelphia National Bank. See supra note 159. This interpretation of hospital cluster markets is difficult to reconcile with the fact that the Federal Trade Commission, an economically sophisticated decisionmaker, neither discussed nor relied on supply substitutability in arriving at its product market definitions in American Medical Intermational and Hospilal Corp. of America, 106 F.T.C. 361 (1985). Indeed, the FTC refers to hospital services as complements in its discussion of market definition in American Medical Int l., 104 F.T.C. at 194. See also supra note 156.

168. See Note, supra note 160; Horizontal Mergers, supra note 35, 139 n.692 (collecting commentary challenging cluster market concept). 
approach ignores or undervalues the significance of competition from firms offering a partial line of services but not all the services in the cluster. In hospital industry terms, cluster markets may lead courts to underestimate the significance of outpatient clinics in restraining some forms of hospital collusion, and so to interdict mergers generating increased concentration among hospitals when the danger of collusion is limited. ${ }^{169}$

Second, concentration figures for cluster market output or capacity are potentially misleading because they award each multiproduct firm a market share equal to an average of that firm's share in providing each of a number of individual services. Thus, one hospital's low share of a region's total patients or beds may obscure its high share in the provision of certain individual services, particularly if those services account for a small fraction of total hospital activities. In consequence, a merger which creates high concentration in the provision of a service for which demand and supply substitutability is limited could readily avoid antitrust challenge under the cluster approach to product market definition when the same transaction would properly receive careful scrutiny under the DOJ Guidelines approach to market definition.

Two approaches to making sense of cluster markets under the DOJ Guidelines methodology for assessing the likelihood of collusion are analyzed below. The first, based on economic relationships of complementarity among clustered products, is unsatisfactory because the role of complementarity in affecting the ability of firms to collude is closer to that of a factor facilitating or frustrating collusion than to the role substitutability plays in market definition. The second approach, a pragmatic one, is more appealing. The pragmatic approach finds clustering a cost-effective tool for implementing the DOJ Guidelines when, as best can be told from available market information, all competing firms sell multiple products or services, firm market shares do not vary significantly across products, and entry conditions are similar across products. In this situation, antitrust analysis will be similar across products or services, so enforcers and courts sensibly conserve resources by treating the services identically in aggregate form. As will be seen, however, the pragmatic justification for cluster markets breaks down when some firms successfully compete with a partial line of services.

a. Should product complements define cluster markets? Cluster markets have been identified among goods or services that are complements in supply, demand, or transactions. ${ }^{170}$ This observation suggests to some commentators

169. If the firms supplying a partial line of services are plausible potential entrants into the cluster, their competitive effect may be taken into account in considering entry barriers. However, an entry analysis will not always correct for an improper market definition. Courts are unlikely to consider outpatient surgical clinics, for example, as potential providers of the full spectrum of hospital services grouped in an inpatient care cluster even though surgi-centers provide demand substitutes for some types of inpatient care.

170. See Horizontal Mergers, supra note 35, 139 n.694 (collecting cases clustering supply complements), 140 n.698 (collecting cases clustering demand complements), 140 n.700 (collecting cases clustering transactions complements). On other occasions, courts have refused to include 
that complementarity might provide a rationale for cluster markets. ${ }^{171}$ The approach is initially attractive because it promises to offer a principled rule to identify the bounds of product clusters based on an economic force, much as the economic force of substitutability bounds relevant markets under the DOJ Guidelines approach.

Three types of complementary products may be distinguished, one in supply and two in demand. ${ }^{172}$ If it is cheaper to produce or distribute two goods together than separately, production technology is characterized by economies of scope and the two goods are supply complements. ${ }^{173}$ Extreme cases of scope economies, in which the creation of one product is a necessary by-product of manufacturing the other-such as beef with hides, or nitrogen with oxygen in an air separation gas process-are sometimes termed coproducts or joint products. Some scope economies seem plausible in the hospital industry: a hospital already offering one surgical procedure may have the equipment, operating rooms, surgeons, anesthesiologists, and support staff available to allow it to offer many other surgical procedures at low marginal cost. ${ }^{174}$ However, little empirical evidence exists on the significance of these economies for hospital operation. ${ }^{175}$

complementary products in the same product market. See Horizontal Mergers, supra note 35, 140 n.699 (collecting cases refusing to place demand complements in the same product market). However, when demand complements are also supply or demand substitutes, courts readily include them in the same product market by applying the usual substitutability doctrines. Kaiser Aluminium \& Chem. Corp. v. FTC, 652 F.2d 1324 (7th Cir. 1981) (basic bricks and basic specialties, substitutes in production while demand complements for steel manufacturing, placed in same product market); United States v. International Tel. \& Tel. Corp., 1971 Trade Cas. (CCH) 173,619 , at 90, 540-41 (N.D. Ill. 1971) (vending machines and manual food service placed in same product market as demand substitutes, although the two are demand complements for some consumers who purchase part of their meals from each source).

171. See American Medical Int l. 104 F.T.C. at 194 (clustered services are complements); see generally Horizontal Mergers, supra note 35 , at 139-40; 2 P. Areeda \& D. TURner, supra note 107, at 1521 a, at 352 (advocating inclusion of joint products in the same product market); Note, Rationalizing Antitrust Cluster Markets, 95 YALE L. J. 109 (1985) (advocating transactions complementarity as the sole basis for product clustering).

172. Horizontal Mercers, supra note 35, at 138-41. A fourth type of complementarity, strategic complementarity, is defined only for firms not cooperating and so is not directly relevant to an assessment of the likelihood of collusion. See Bulow, Geanakopolis \& Klemperer, Multimarket Oligopoly: Strategic Substitutes and Complements, 93 J. PoL. ECON. 488 (1985). Furthermore, network externalities - the benefits a customer obtains from buying a product or service compatible with the purchases of other buyers-may constitute a fifth type of complementarity. See, e.g., David, Clio and the Economics of Qwerty, 75 AM. ECon. Rev. 332 (Papers and Proceedings 1985).

173. See, e.g., Spence, Contestable Markets and the Theory of Industry Siructure: A Review Article, $21 \mathrm{~J}$. Econ. Literature 981 (1983); Panzar \& Willig, Eronomies of Scope, 71 Am. Econ. Rev. 268 (Papers and Proceedings 1981).

174. Even if some inputs cannot be employed in both procedures-for example, if surgeons with a gynecological specialty lack the training and experience to undertake heart surgery-it is plausible that enough other inputs can be shared so as to make the marginal cost of offering the second procedure, given that the first is offered, lower than the cost of creating a new facility with the sole purpose of offering the second procedure.

175. One study finds diseconomies of scope for the offering of medical-surgical services, maternity services, and emergency room services together with each other, but finds scope economies for the offering of pediatrics with these other services. Cowing \& Holtmann, Multiproduct Short-Run Hospital Cost Functions: Empinical Evidence and Policy Implications from Cross-Section Data, 49 Southern ECon. J. 637, 648-50 (1982); see Grannemann, Brown \& Pauly, Estimating Hospital Cosls, $5 \mathrm{~J}$. Health Econ. 107 (1986) (scope diseconomies between emergency department and inpatient care). 
From the point of view of buyers, goods may be complements in two ways: as demand complements or transactions complements. Demand complements are, loosely speaking, goods that many buyers consume in concert, such as peanut butter with jelly or cameras with film. Hence, if the price of one demand complement rises, consumers reduce their purchases of both products. ${ }^{176} \mathrm{~A}$ variety of services in the hospital industry might be demand complements, ${ }^{177}$ including surgery and inpatient care, ${ }^{178}$ intensive care and other forms of inpatient care, ${ }^{179}$ or various diagnostic procedures. ${ }^{180}$

Transactions complements are goods that buyers prefer to purchase together, without necessarily consuming them together. ${ }^{181}$ The goods sold by a supermarket are likely transactions complements because consumers would pay a slight premium to buy milk and vegetables in one stop rather than make separate visits to the dairy and the vegetable stand, even if the two products will be eaten at separate meals. Most hospital services could be transactions complements. For example, consumers often prefer to undergo diagnostic tests and medical treatments in one hospital visit rather than purchasing these services at different times. Similarly, the hotel services which a hospital provides as a part of inpatient care would not be desired by patients except in conjunction with nursing and other medical services. ${ }^{182}$

If complementarity is to serve as the basis for product market definition, then this economic force must play a role in antitrust analysis of market power comparable to that of substitutability, the basis for market definition under the DOJ Guidelines, rather than the role of a factor facilitating or frustrating collusion. The DOJ Guidelines radically distinguish between economic forces that will impede cartel success assuming the best efforts of cartel members to cooperate, and economic forces which increase or reduce the incentive of each member to cooperate. Forces which will undercut cartel success even

176. See generally J. Henderson \& R. Quandt, Microeconomic Theory: A Mathematical Approach 31 (3d ed. 1980).

177. See Frech, supra note 98, at 266 (" $[\mathrm{M}]$ any hospital services are strong complements to each other. Hotel services, meals, blood tests, X-rays and surgery are all necessary to produce inpatient surgical service.")

178. Surgical patients generally require post-surgical inpatient care, and some patients hospitalized for illness also require surgery.

179. Intensive care patients likely require inpatient care when they improve, and some hospitalized patients may require intensive care in the course of their treatment.

180. Patients with some complaints may require both $x$-rays and blood analyses in order to distinguish possible diagnoses; in these cases the procedures would be demand complements.

181. See generally Note, supra note 171. These goods can be thought of as a special type of demand complement: if goods are indexed by time of purchase, consumers prefer to acquire similarly timed goods in concert.

182. Cf. United States v. Rockford Memorial Corp., No. 88-C-20186, slip op. at 21 (N.D. Ill. Feb. 23,1989 ) ("In tandem with overnight care, the hospital has assembled a variety of services "under one roof.' This ability to perform a variety of tests and procedures in one place is . . unmatched by a non-hospital health provider."), appeal filed.

Hospital services may also be transactions complements from the point of view of insurers purchasing prospective patient care. For example, an HMO wishing to offer a variety of hospital services to its patients in the event they need care must contract with hospitals to provide a full line of services. It may be cheaper for the HMO to contract with a single hospital for all the necessary services than to provide those services through contracts with multiple hospitals. 
given perfect cooperation, namely demand and supply substitutability, are incorporated into the market definition process. ${ }^{183}$ Forces which might raise or decrease the incentive of a cartel member to cooperate fully with its colluding rivals are addressed later, after markets are defined.184 Concentration is the first economic issue evaluated after market definition because the number of colluding rivals has historically been considered the most important determinant of the difficulty of cartel coordination and the ease of cheating on the cooperative agreement. ${ }^{185}$ Other factors facilitating or frustrating collusion are also addressed following market definition as evidence that might rebut a presumption of anticompetitive effect resulting from concentration. ${ }^{186}$

As will be demonstrated below, each type of complementarity plays an economic role in affecting the likelihood of collusion comparable to a factor facilitating or frustrating collusion. While each type of complementarity provides an incentive for producers of product complements to reduce simultaneously the output of all complements, this incentive generally does not limit the success of a cartel in which all members are cooperating to the extent possible. ${ }^{187}$ Hence, complementarity is not comparable to a factor which should be considered in market defintion.

i. Effect of supply complementarity. When a firm produces supply complements, a reduction in the output of any one product in effect raises the marginal cost of producing (the last units of) its complement, as scope economies must be sacrificed to produce those units. In consequence, if a multiproduct firm reduces its output of one good, it has an incentive to reduce as well its output of all other products complementary in supply. ${ }^{188}$ Every other firm producing the supply complements has similar incentives, so collusion to reduce the output of one product alone ${ }^{189}$ will lead to a decreased output of its supply complements.

183. See supra text accompanying notes 139-42 (market definition).

184. Ease of entry is treated as a factor facilitating or frustrating collusion capable of rebutting a presumption of anticompetitive effect arising from concentration. United States v. Waste Management, Inc., 743 F.2d 976 (2d Cir. 1984). However, entry plays a role in antitrust analysis similar to supply substitution. See infra note 287. In consequence, the Federal Trade Commission is moving toward evaluating the significance of entry before that of concentration-closer to the market definition step of antitrust analysis than the facilitating factors step. B.F. Goodrich Co., 1988 Trade Reg. Reports (CCH) ๆ 22,519, at 22,142-46 (F.T.C. 1988); Echlin Mfg. Co., 105 F.T.C. 410, 487

(1985). See infra notes $286-305$ and accompanying text.

185. See infra notes $265-85$ and accompanying text.

186. See infra notes 305-35 and accompanying text.

187. This conclusion holds regardless of whether the complementary goods are sold by the firms selling the cartelized product. While supply complements are invariably sold by the multiproduct firms that sell the cartelized products, and transactions complements are usually sold by such multiproduct firms, demand complements are often sold by different firms.

188. 2 P. Areeda \& D. Turner, supra note 107, at I $521 \mathrm{a}$, at 352

189. A cartel composed of multiproduct producers may find it possible to coordinate a reduction in output and increase in price for some but not all products if, for example, cheating is easy to monitor and police in some markets while difficult in other markets 
This by-product of collusion over the first product will not generally make a single product cartel unprofitable because the reduction in output of the complementary good allows the firm to avoid sales of the complementary product generating low marginal revenue. ${ }^{190}$ When the colluding firms are unable to make marginal adjustments in output, however, it is possible that cooperation will not be profitable among sellers of supply complements. ${ }^{191}$ In neither case would profits likely increase significantly were the supply complement brought into the collusive arrangement; the complement is already in effect present by virtue of the joint production technology. Thus, while supply complementarity may influence the total profits available to colluding firms and thereby affect individual firm gains from cooperation, the exclusion of products complementary in supply from a cooperative

190. This result can readily be demonstrated for joint products, the extreme case of scope economies, under one set of plausible assumptions about the marketplace. Assume that a firm producing joint products makes one unit of good $A$ for every unit of good $B$, at a joint marginal cost denoted $M C$. All firms are assumed to have identical cost functions, and marginal cost is assumed constant for outputs between competitive and cooperative levels. Before the cartel was organized, the two products sold at prices $P^{n}$ and $P^{b}$ respectively. If the market was competitive at that time, $M C=P^{n}+P^{b}$. If both products have downward sloping industry demand curves, marginal revenue on each product (from the point of view of the industry as a whole) is less than price. Thus, $M C>M R^{\prime \prime}+M R^{\prime \prime}$.

To raise the price of $\operatorname{good} A$, colluding firms must sell less of that good. Assume that the only profitable way to reduce output is to reduce production of both products (rather than preserving production of $A$ and $B$ while destroying some units of good $A$ ). On the margin, a cooperating firm gains by saving $M C$. However, the firm loses $M R^{n}+M R^{h}$, the marginal revenues available from selling the last unit of the joint products produced. As $M C>M R^{\prime \prime}+M R^{b}$ at the previous competitive equilibrium, some output reduction necessarily increases the firm's profits.

This result would not change were the price in market $B$ to remain at $P^{b}$, as might occur were single product firms able to employ an alternative technology to produce good $B$ at a marginal cost of $P^{b}$. In this case, $M C>M R^{\prime \prime}+P^{b}$ at the competitive equilibrium. Now a reduction in the output of both products by multiproduct producers colluding over good $A$ saves each firm $\operatorname{costs}$ equal to $M C$, but causes each producer to forgo revenues equal to $M R^{\prime \prime}+P^{b}$. Collusion in market $A$ remains profitable on the margin, even though the practice no longer raises the revenues available from the last unit sold in market $B$.

Were the goods not extreme supply complements, the firm would likely prefer to reduce the output of good $A$ by more than the output reduction chosen for joint products if the demand curve for good $A$ is more inelastic than the demand curve for good $B$.

191. The unprofitability of cooperation in this special case turns on production indivisibilities rather than supply complementarity. Suppose that a multiproduct firm produces two goods, denoted $A$ and $B$. Assume extreme supply complementarity: The firm can produce one unit of each good for a total expenditure of $\$ 18$ or else two units of each at a total cost of $\$ 28$, but it cannot manufacture the goods in unequal amounts or produce more than two units. Suppose further that each good sells for a market price of $\$ 7$, and that there are a large number of firms with identical production technologies as the first. Under these assumptions, each firm will choose to produce two units of each good. At this output, the firm receives total revenues of $\$ 28$, equal to firm costs, and earns no economic profit.

The firm of interest might consider participating in a collusive arrangement with its rivals under which all firms would halve their output of good $A$. in the expectation based on demand conditions that the market price for $A$ would rise to $\$ 10$ before it would become profitable for entrants to produce $A$ alone using some other technology. However, if an alternative technology for producing $\operatorname{good} B$ is available, and if new entrants using that technology would be attracted by a market price above $\$ 7$, the firm will choose not to participate in the cartel. If it reduces its output of good $A$ to one unit, it necessarily reduces its output of $B$ as well. The firm would find that it spends $\$ 18$ to produce two products generating revenues of $\$ 17$, so it loses $\$ 1$. Nor could the firm profit by producing two units of each good and destroying one unit of $\operatorname{good} A$; this strategy would generate a loss of $\$ 4$. 
arrangement will not generally make unprofitable an otherwise profitable cartel. ${ }^{192}$

ii. Effect of demand complementarity. When a firm sells a good having demand complements, it recognizes that an increase in the price of that product, as might result from cartel behavior, reduces the demand for the complementary products regardless of whether it or another firm produces the complementary goods. Multiproduct firms collaborating on a reduction in output for one good thus necessarily also collaborate to reduce the sales of those demand complements they also produce. In consequence, aggregate profits will likely be lower for a colluding firm also selling demand complements for the cartelized product than for a corresponding single good producer in the cartel. But the injury multiproduct producers of demand complements inflict on themselves, and their resulting disincentive to cooperate in a cartel over the first product, will typically not deter cartel formation whether or not the cartel also is able to coordinate price and output

192. Cf. Note, supra note 171, at 117 (multiproduct firms selling supply complements can collude on single products profitably). 


\section{of the second product, ${ }^{193}$ although exceptions to this generalization may occur. ${ }^{194}$}

193. For example, suppose two demand complements, denoted $A$ and $B$, have the following symmetric inverse demand curves: $P^{n}=100-3 Q^{n}+Q^{h}$ and $P^{h}=100-3 Q^{b}+Q^{n}$. (As a technical matter, the assumption that these linear demand functions are derived from maximizing the utility function of the same representative consumer requires that the coefficients of the complementary products be identical, here unity.) Assume further that only one firm produces both goods. For this firm, fixed costs are zero, and the marginal cost of producing either product equals the quantity of that good it produces: $M C^{n}=Q^{a}$ and $M C^{b}=Q^{b}$. The profits available to this hypothetical single firm would also be available collectively to cartel members whose aggregate demand and marginal cost functions equal those assumed for this one producer. Thus, structural features affecting the incentives of this firm to act as a monopolist equally suggest the incentives of firms in an oligopoly to collude.

Two benchmark equilibria may be derived for this problem. First, if the firm acts as a price taker in both markets (case I), an assumption that defines the competitive equlibrium, it can be shown that it will produce 33.3 units of each good, sell them at a price of 33.3, and earn profits of 555.6 in each market for a total profit of 1111.1 . Second, if the firm instead acts as a monopolist in both markets (case II), it will sell 20 units of each product at a price of 60 in each market, and earn 1000 in profits in each market for a total profit of 2000.

To determine the significance of the sale of a demand complement on a firm's incentives to collude, the profits of a single product monopolist are compared with those of a multiproduct firm monopolizing only one market. Assume that a single producer monopolizes good $A$, while good $B$ sells in a competitive market (case III). This monopolist recognizes that the output and price of good $A$, which it controls, affect the demand for $\operatorname{good} B$, and thereby affect the equilibrium output in that market and in turn influence the demand for good $A$. With this indirect feedback effect in mind, the single product producer will choose to make 19.2 units of good $A$ and sell them at a price of 72.1 . It will earn profits of 1201.9. (The competitive $B$ industry would then sell 29.9 units of that product at a price of 29.8 and earn profits of 444.2.) This monopolist reduces the output of good $A$ to a level even lower than that of the monopolist in both markets because it does not bear the costs of the negative demand externality it imposes on sellers of the complementary product.

A final case is employed to analyze the effect of demand complementarity on the incentive of a multiproduct firm to monopolize one product when its demand complement is not monopolized. Assume that a multiproduct producer of both goods recognizes its market power over product $A$ but acts as a price taker in market $B$ (case IV). In other words, a multiproduct firm producing both products observes that its output decision in market $A$ affects the demand curve it faces in market $B$. But unlike the monopolist in both markets considered in case II, it does not recognize that it faces a downward sloping demand for the second good. In this situation, the firm produces 20.4 units of $\operatorname{good} A$, which sell at a price of 68.9. It also manufactures 30.1 units of $\operatorname{good} B$, which sell for the price of 20.4. Firm profits are 1197.6 in market $A$ and 405.8 in market $B$, for a total profit of 1603.4 . This firm produces slightly more of good $A$ than does the single product monopolist (case III) because it internalizes the negative externality inflicted on the demand for good $B$ by a monopoly in good $A$. While firm profits in market $A$ are slightly lower in this case than for the single product monopolist (1197.6 as compared with 1201.9 in case III), aggregate firm profits of 1603.4 substantially exceed the aggregate profits of 1201.9 for the single product monpolist. Furthermore, while the multiproduct firm able to monopolize only one market earns fewer profits than the mulitproduct firm able to monopolize both markets ( 1603.4 in case IV versus 2000 in case II), the multiproduct firm limited to monopolizing market $A$ earns substantially more profits than a multiproduct producer forced to act as competitively in both markets (1603.4 in case IV versus 1111.1 in case 1 ).

In this example, the incentives of the single product firm to monopolize good $A$ (case III) are not significantly different from those of the multiproduct firm able to monopolize only one market (case IV). Further, the total profits available to the multiproduct firm able to monopolize only one market (case IV) are substantially in excess of the profits earned by a competitive industry (case I). Hence, demand complementarity did not reduce the incentive of a multiproduct firm to monopolize one market alone.

194. Suppose the two demand complements $A$ and $B$ each sell at the market price of $\$ 7$, and each good costs $\$ 6.50$ to produce. Some firms produce only one of these products, and others produce both. No incumbent firm can expand its output at a marginal cost of less than $\$ 8$ for each good, and new entry would also be forthcoming in both markets at a price of $\$ 8$. Suppose further that the producers of good $A$ recognize that if they each reduce their output by $20 \%$, the market price will 
The factors affecting the profitability of single product collusion for the multiproduct producer of demand complements are readily identified. A multiproduct firm selling a demand complement as well as the cartelized product experiences the least potential disincentive to cartel formation when the firm's sales revenues from the complement are small relative to its revenues from the cartelized good, when the degree of complementarity is weak, and when the product subject to collusion has an inelastic demand curve. On the other hand, a multiproduct producer may find it unprofitable to participate in a cartel to raise the price of one product when the firm has much greater sales of a demand complement, the goods are strong complements, and the good subject to collusion has an elastic demand curve. ${ }^{195}$ In such a case, the cartel in the first product will increase firm revenues derived from that market, but that benefit could be outweighed by lost revenue in the large market for the complementary product if the high price for the first good dramatically reduces demand for the complement.

rise to $\$ 8$. Because the goods are demand complements, the higher price of good $A$ will generate a $10 \%$ reduction in the demand for good $B$ and the market price for good $B$ will decline to $\$ 6.90$.

$A$ firm producing good $A$ but not good $B$ will profit from a cooperative agreement to reduce output by $20 \%$. If this firm makes five units of $\operatorname{good} A$, its profits are $\$ 2.50$ before collusion. But under the cooperative arrangement, the firm's profits will rise to $\$ 6$, even though its output of good $A$ declines to four units. In contrast, a firm producing both products might find collusion in the $A$ market unprofitable. If that firm produces five units of good $A$ and 50 units of good $B$, its precollusive profit is $\$ 2.50$ on $\operatorname{good} A$ and $\$ 25$ on $\operatorname{good} B$, for a total profit of $\$ 27.50$. When the firm joins the cartel, it reduces its production of good $A$ to four units, and finds that its share of the decreased market demand for good $B$ allows it to sell only 45 units. Its profit on good $A$ rises to $\$ 6$, but its profit on good $B$ falls to $\$ 18$, so its total profit declines to $\$ 24$. This firm would not lose money, however, if the collusive price of good $A$ is $\$ 9$ or more, or if the firm's share of revenues from $\operatorname{good} B$ is reduced

In this example, the reduction in demand for a demand complement removed the incentive of a multiproduct producer to collude on one product alone. If instead the multiproduct firm was able to collude on both goods simultaneously, it likely would have found cooperation profitable. For example, a $20 \%$ reduction in the output of both products might generate a market price of $\$ 7.80$ for each. Under this assumption, a firm formerly producing five units of good $A$ and 50 units of good $B$ would, in concert with its rivals, reduce output to four units of good $A$ and 40 units of good $B$. Its profits would rise from $\$ 27.50$ to $\$ 57.20$.

195. These are the factors causing collusion to be profitable in the example described supra note 194.

This situation is most likely to arise in the context of collusion in the sale of one product by vertically integrated producers. An integrated firm making both an upstream input and a downstream product, such as a firm producing both steel and fabricated steel products, is selling demand complements. Consumers of fabricated steel goods are in effect purchasing both the steel and the fabrication. Further the goods may be strong demand complements; the fabricator may have little leeway to vary the steel content of many of his downstream products. Consequently, a firm that is primarily a fabricator, with very little captive steel production, may not find it profitable to participate in a steel cartel if the cartel price is at the high level preferred by unintegrated steel producers. Indeed, this producer might undermine a steel cartel by expanding captive production. This firm would, however, profit from a fabricated goods cartel. In contrast, a firm primarily producing steel with very small fabrication operations would find the steel cartel very profitable, but would find a fabrication cartel unprofitable if the cartel price is at the high level preferred by unintegrated fabricators. While some output reduction and price rise in one or both markets would profit both these firms, unintegrated firms and integrated firms may have substantially different views as to the best output reduction in each market. Under such circumstances, horizontal coordination may be difficult to arrange. Moreover, vertical integration may increase the ability of cartel members to cheat secretly, thereby deterring cartel formation. See infra note 200 . These issues are discussed in detail in B.F. Goodrich, 1988 Trade Reg. Rep. (CCH) \ 22,519, at 22,161-66 (F.T.C. 1988). 
Even in this extreme case, however, some output reduction for both goods will profit this multiproduct firm; this producer's complaint is that the cartel chose a mix of output reductions very profitable for other cartel members but unprofitable for it. ${ }^{196}$ Thus, if a multiproduct producer of demand complements acts in the best interests of the cartel, and if the cartel chooses an output reduction that maximizes joint profits of all members, then the firm would always be willing to participate in a collusive agreement. ${ }^{197}$

Unincluded demand complements are qualitatively less troublesome to a cartel than unincluded demand substitutes. Consider a case of strong demand substitutability: Assume that two products, such as California and New York table wine, are virtually interchangeable for buyers. Assume also that each good can be produced with constant marginal cost, and that the costs of making each are nearly identical. No matter how much the sellers of the first product reduce their output in an attempt to raise price, the market price of both will remain near marginal cost. By reducing output, collusive sellers of the first good will succeed in lowering rather than raising their revenues, so will almost surely find collusion unprofitable. Compare a case of strong demand complementarity: Two products are consumed in fixed proportions, one unit of each. These products might be nuts and bolts, or lift tickets and hotel rooms at a ski resort. ${ }^{198}$ In this case, consumers care only about the sum of the two prices; buyer demand is for both goods together. If the output of one of these goods is reduced, as by a cartel among the producers of that product, consumers will reduce their purchases of the other good and will bid up the total price they are willing to pay for the package of the two products. Unless joint demand is elastic, this action will raise the total revenues available to producers of the two goods, allowing the producers of each to profit. ${ }^{199}$ As unincluded substitutes are much more likely than unincluded complements to reduce cartel profitability, it is appropriate that demand substitutes but not demand complements be taken into account during the market definition stage of antitrust analysis. ${ }^{200}$

196. This divergence of interests arises because the multiproduct producer internalizes the demand externality created by complementarity, while the single product producer does not. Hence, a cartel composed of some single product producers and some other firms that also produce demand complements may have a difficult coordination task, to the extent the interests of the single product firms and the multiproduct firms differ.

197. In some cases, side payments between other cartel members and this firm may be required to induce the firm to participate, further increasing the difficulties of cartel coordination.

198. The goods might also be downstream consumer products and upstream inputs. See infra note 195.

199. The sellers of the first product may be able to earn monopoly profits by raising the price of that good even if they are unable to raise the total price of both goods to consumers. Consumers will happily pay more for the first good if the price of the demand complement is reduced, as consumers care only about the total price. Further, so long as the lower price for the demand complement exceeds the sum of its marginal cost plus its average recoverable fixed cost, the competing producers of the demand complements will remain in the marketplace while accepting a revenue reduction, and the equilibrium output and market price for the package need never change. Hence the cartel in one good can profit by appropriating the rents that a competitive market would have awarded its demand complement. The author is indebted to Steven Salop for this observation.

200. Demand complementarity may also create a second difficulty for cartel formation when one firm sells all the complementary goods. Multiproduct sellers of demand complements may find it 
iii. Effects of transactions complementarity. Sellers of transactions complements must recognize that consumers care about the total price of their consumption bundle but are not otherwise concerned about the price of individual goods. For example, grocery store shoppers may primarily be interested in the aggregate cost of the goods in their grocery shopping cart, and may not otherwise be concerned about the price of milk. If goods are transactions complements, a cooperative agreement to raise the price of one good could be undercut by firms that lower the price of one of the good's transactions complements. ${ }^{201}$ Because a cartel composed of multiproduct sellers must foreclose this option for cheating, the cartel may find it necessary to raise price on all products with transactions complementarity sold by member firms; the members of a grocery store cartel may agree to raise their markup on all products in the store, across the board, rather than limit the price raise to a handful of individual products such as milk and other dairy goods. ${ }^{202}$ But if the meat department in the grocery were owned by a separate firm from the rest of the store, for example, the grocery need not fear that its meat subcontractor would lower price to undercut collusion

possible to cheat on a cartel in one good by lowering their price of its demand complement for consumers willing to buy both goods from it. However, lowering the price of a complement allows a multiproduct firm to cheat on a cartel only if the firm is able to increase sales of the cartelized product. A tied purchase requirement is one mechanism for accomplishing this result. This mechanism for undercutting a cartel cannot be employed unless consumers purchase all demand complements from one buyer, as when goods are strong transactions complements. See infra notes 201-04 and accompanying text. Another situation in which consumers purchase demand complements simultaneously occurs when consumers buy the downstream output of a vertically integrated producer. This firm in effect sells the demand complements of upstream inputs and downstream fabrication. See infra note 195. In both cases, the difficulty for cartel formation does not arise if multiproduct firms act in the best interest of the cartel. Thus, this problem is best treated as a factor facilitating collusion rather than as a concern of market definition.

201. See Note, supra note 171 , at 119 ; supra note 200.

For an example of how transactions complementarity may facilitate cheating on a cartel, suppose that consumers invariably buy one unit of product $A$ and one unit of product $B$ each week, and that it costs consumers an extra $\$ 1$ to shop at two stores rather than one because of the extra time involved. Then goods $A$ and $B$ are transactions complements.

Suppose that a store sells 10 units of goods $A$ and $B$ each day for $\$ 7$ each. Assume further that these goods cost the store $\$ 7$ each, so it earns no economic profit. If there are many identical stores, and all raise the price of good $A$ to $\$ 8$, suppose that each would then sell only eight units of that product. Cooperation limited to good $A$ would be desired by each, as it would create profits of $\$ 8$. If such cooperation occurs, however, each firm would likely have a strong incentive to lower its price on good $B$ to $\$ 6.50$, even though that price is below the cost of good $B$. Consumers will discover that they can obtain one unit of both $A$ and $B$ for $\$ 14.50$ at a store which lowers the price of $B$, while their shopping trip will cost $\$ 15$ otherwise. In consequence, any one store might be able to attract, for example, 40 customers purchasing one unit of each product if it is the only store colluding on good $A$ and simultaneously discounting good $B$. In that case the store will earn a total profit of $\$ 20$. Competition on good $B$ will likely emerge, until its price falls to $\$ 6$ and firms no longer earn economic profits despite their cooperation on the price of good $A$. This problem with collective action would be remedied by an agreement not to reduce the price of good $B$ when increasing the price of good $A$ or an agreement to raise the price of both products.

202. The fact that milk is a transactions complement for other goods when sold in a grocery store does not mean that a dairy cartel desiring to collude on the price of milk must make an agreement with the vegetable cartel and the meat cartel. Dairies produce only one product, milk at wholesale, while grocery stores distribute a variety of transactions complements at retail. 
involving the remaining grocery products. ${ }^{203}$ Thus, if collusion over one set of products, such as the retail sale of dairy goods, would be profitable, it will never be undercut by the failure of the cartel to include other firms selling transactions complements; it will only be undercut by cartel members choosing not to act in the best efforts of the cartel by cheating through lowering the price of those complements which they also sell. Hence transaction complementarity operates for multiproduct sellers like a factor facilitating or frustrating collusion, by altering the incentives of such sellers to make their best efforts for cartel success, rather than as an economic force impeding those best efforts, which should be taken into account in market definition. ${ }^{204}$

iv. Complementarity as a market definition criterion. Each type of complementarity has been shown to play a role in affecting the likelihood of collusion comparable to a factor facilitating collusion rather than an economic force suitable for consideration during market definition. ${ }^{205}$ If complementarity is nevertheless allowed to form a basis for product market definition, two analytic problems will be created. First, using complementarity as well as substitutability as a market definition criterion may generate inappropriate product markets. When goods are moderate but not strong complements, or when there are substitutes for some but not all goods in the cluster, it may well be misleading to expand provisional product markets by adding complements instead of adding substitutes. ${ }^{206}$ For example, suppose market power inferences regarding hospital mergers are derived from a cluster market defined by acute inpatient hospital care, based on some form of complementarity among hospital services. At some point the presence of new institutions competing with respect to some but not all of those services, such as free standing ambulatory or surgical clinics, belies those inferences. ${ }^{207}$ Yet the complementarity logic does not assist in

203. The grocery is likely to benefit from this action because the reduction in market basket prices would shift business to it from its rival colluding firms. The meat counter would not benefit because its price reduction would cause it to sell at a price below marginal cost unless side payments were arranged.

204. Even if a retail dairy cartel is made unsuccessful by the incentives of grocery store sellers of milk to cheat by lowering the price of other grocery products, a retail grocery cartel might be successful. This observation suggests that a merger of two groceries analyzed in both a dairy product market and a grocery product market might appear more anticompetitive in the grocery market than the dairy market. For another example of a merger more troubling in a broad product market than a narrow one, see supra note 147.

205. Furthermore, it is possible to consider fully the significance of complementary products by treating them as a factor facilitating or frustrating collusion. See infra notes $321-26$ and accompanying text. It is therefore unnecessary to consider their effect during market definition.

206. Even if this process is not misleading, it may be complex. When provisional product markets may be expanded either by adding close complements or by adding close substitutes, the market definition task requires choosing between dissimilar alternatives.

207. See, e.g., Hospital Corp. of Am., 106 F.T.C. 361, 465-66 (1985) (narrowing the cluster in response to new forms of competition), aff'd, 807 F.2d 1381 (7th Cir. 1986), cert. denied, 481 U.S. 1038 (1987). 
identifying situations when markets based on substitutability are to be preferred to the cluster based on complementarity. ${ }^{208}$

Second, product market definitions based on complementarity may confuse rather than clarify a court's or enforcer's understanding of the economic forces affecting the likelihood of industry collusion. For example, when goods have strong complements, the monopoly profits from cooperative action most likely derive primarily from the subset of those products lacking substitutes. Indeed, it is necessary that some products in the cluster meet the market definition standards involving substitutability for any product in the group to increase in price as a result of producer collusion. ${ }^{209}$ Thus, it is the absence of substitutes, not the presence of complements, that confers the possibility of market power on producers of a product or service, although the presence of complementary goods may affect the incentives of such producers to take advantage of their potential ability to increase revenues through a cooperative reduction in output. Product market definition based exclusively on the extent of demand and supply substitutability preserves the focus of antitrust concern on the necessary condition for cartel success. ${ }^{210}$ It is misleading to shift attention away from the product or service where collusion can generate supracompetitive pricing in order to highlight one factor (complementarity) potentially facilitating or frustrating collusion, particularly when this factor will rarely be the most significant factor affecting firm incentives to collude.

b. Pragmatic approach to product clusters. ${ }^{211}$ A superior approach to making sense of cluster markets applies the term solely for descriptive and analytic

208. Cf. Note, supra note 160 (new competition in banking makes previous cluster markets inadvisable).

The clustering of product complements can also increase market definition difficulties if the geographic extent of competition for each good differs, as might easily be the case for supply complements. In such a case, geographic market definition will be confused. See infra note 237 and accompanying text.

209. For example, if beef producers would be able to raise the price of beef through a cooperative output reduction, then beef satisfies the product market definition algorithm of the DOJ Guidelines. Even if beef producers must also reduce their output of beef's supply complement, hides, in order to take advantage of their market power in beef, the higher price of beef will contribute to increasing aggregate firm profits. If hides also form a relevant product market, the reduction in output of hides may increase profits in that market as well, so a separate antitrust analysis of the hides market may demonstrate that the beef market collusion creates anticompetitive problems in more than one market. But if neither beef nor hides forms a relevant product market based upon the substitutability considerations of the DOJ Guidelines, neither good will increase in price as a result of producer collusion to reduce the output of the two complements simultaneously.

210. However, defining a broader market aggregate including complements for the product lacking substitutes is not formally inconsistent with the DOJ Guidelines because a large number of product markets satisfy the DOJ Guidelines methodology. See supra notes 147-48 and accompanying text.

211. The term "pragmatic approach" may be misleading to the extent it suggests, incorrectly, that the resulting markets do not reflect the economic principles of the DOJ Guidelines. Rather, this approach defines cluster markets in order to apply the DOJ Guidelines analysis more effectively by avoiding unnecessary complexity, but only in situations where the result would not change were the market power analysis undertaken for individual product markets. The author is indebted to George Priest for this observation. 
convenience in situations where it will not be misleading. In two related situations, the cluster approach will likely generate the same market power inferences as the DOJ Guidelines substitutability analysis while minimizing analytic complexities. First, when the same firms sell the same set of products, which do not happen to be substitutes, in the same geographic areas with similar market shares, and when each individual product would constitute a product market under the DOJ Guidelines, the antitrust analysis of each would be so similar in practice that no loss of analytic power comes from treating the products as a collection. For example, if cardiac surgery and computerized axial tomography (CAT scans) are neither demand nor supply substitutes, it would be sensible to incorporate these procedures in an inpatient hospital care cluster market when each procedure would form a product market individually under the usual substitutability tests, and when they are offered by the identical set of hospitals with similar market shares.

Alternatively, if finely partitioned market share data are unavailable, concentration in many individual product markets will necessarily be estimated with the same aggregate figures. If there is no compelling reason to believe demand and supply substitutability opportunities, entry conditions, or market shares differ significantly across individual products, then the antitrust analysis will be similar for each good so they may conveniently be analyzed as a collection. ${ }^{212}$ Thus, cardiac surgery and neurosurgery might be placed in the same surgery cluster market if statistics on surgical patients days do not distinguish between these procedures, and if there is no reason to believe substitution opportunities, entry conditions, or market shares differ among them. But this cluster is less compelling, for example, if one hospital specializes in one procedure so is likely to have a particularly high share of that service, if the equipment employed in orthopedic surgery can be used in heart surgery but not neurosurgery, or if there is a nationwide shortage of cardiac surgeons and a glut of neurosurgeons.

This pragmatic approach to cluster market definition is not inconsistent with the Supreme Court's delineation of cluster markets in the bank cases. The Court's emphasis on the "commercial realities" that insulate products within the cluster from outside competition ${ }^{213}$ suggests that the same firms compete across all products with similar shares. Under this interpretation, the Court's cluster market of banking services makes sense if, for example, banks with large deposits also have large loan portfolios and extensive trust

212. The Department of Justice takes a similar view. 60 Minutes with Charles F. Rule, Assistant Attorney General, Antitrust Division, 57 Antrrrust L.J. 257, 274-75 (1988); Rule, supra note 115, at 126 27. Differences in market shares across services in hospital market clusters may be substantial, however. One commentator suggests that the individual services grouped in the cluster market defined by the FTC in its Hospital Corp. of America opinion differ widely in concentration from the aggregate concentration figures. T. MCCarthy, Emerging Competitive Issues in Health Care MARkets, Eighth Annual Antitrust \& Trade Regulation Seminar of the National Economic Research Associates, Inc. (July 10, 1987).

213. United States v. Philadelphia Nat'l Bank, 374 U.S. 321 , 356-57 (1963). 
administration services, and regulatory barriers limit entry into these markets. ${ }^{214}$

The Court also adopted a pragmatic market definition approach unrelated to substitutability or complementarity in undertaking its geographic market definition in Grinnell, ${ }^{215}$ but not in its product market definition where the cluster market recognized by the Court was likely predicated on supply substitutability. ${ }^{216}$ The Court in Grinnell defined a national market for accredited central station protective services when it expected little variation in concentration and competitive conditions across individual geographic markets. In a large number of geographic regions, the same firm was the exclusive provider of central station services. ${ }^{217}$ Further, in each location a large number of customers were unwilling to purchase protective services other than through a central station provider. ${ }^{218}$ Thus, one producer was likely a monopolist for central station protection in each of a large number of regions of the country. Rather than analyze the similar markets for several services in over 100 cities, the Court chose to define a cluster market for these services and a nationwide geographic market. ${ }^{219}$ Assuming the product market was correctly defined, the defendant's 73 percent nationwide market share of central station protective services ${ }^{220}$ probably did not misrepresent its monopoly power in the local regions underlying this geographic market definition. ${ }^{221}$

The pragmatic rationale will not justify a cluster market when some firms sell subsets of the clustered goods but not the full line. When partial line sellers are present, a different collection of sellers can offer each good,

214. The product market involving a cluster of banking services may also be consistent with a rationale for clustering based on demand or transactions complementarity, or on supply substitutability. The district court in the Philadelphia National Bank case found that "Each [banking service] is an integral part of the the whole, almost every one of which is dependent upon and would not exist but for the other." United States v. Philadelphia Nat'l Bank, 201 F. Supp. 348, 363 (E.D. Pa. 1962), rev'd on other grounds, 374 U.S. 321 (1963). In affirming the district court's product market definition clustering banking services, the Court noted both "cost advantages" for banks in providing personal loans relative to small-Ioan companies-suggesting supply substitutability with other banking services, the basis for the cluster market defined in Grinnell-and a "settled consumer preference" for bank provision of financial services, suggesting demand or transactions complementarity. Philadelphia Nal'l Bank, 374 U.S. at 356-57.

215. United States v. Grinnell, 394 U.S. 521 (1966). The author is indebted to Terry Calvani for helpful discussions concerning this point.

216. See supra note 149.

217. Crinnell, 384 U.S. at 578.

218. Alternatives, such as watchmen or audible alarms, differ in "utility, efficiency, reliability, responsiveness, and continuity . . . For many customers, only central station protection will do." Grinnell, 384 U.S. at 574. But see id. at 590-91 (Fortas, J., dissenting).

219. The Court recognized that individual stations operate only within an area 25 miles in radius, id. at 575 , so it in effect defined a geographic cluster market as well as a product cluster market. The dissent found the majority's nationwide geographic market indefensible because of the absence of demand and supply substitutability. Id. at 588-89 (Fortas, J., dissenting).

220. Id. at 578 .

221. The dissent excoriated the majority for not undertaking a "market-by-market" analysis of competition, but recognized that "it might well be the case" that defendant had monopoly power in "a number of those local areas." Id. at 589-90 (Fortas, J., dissenting). However, the dissent also presented some evidence of differences in concentration across markets, which would recommend a market-by-market analysis. Id. at 592. 
multiproduct sellers may have widely differing market shares for each product, and entry conditions likely vary across goods. Under these circumstances, cluster markets will misrepresent the nature of competition for many if not all the products clustered. ${ }^{222}$ Thus, the "acute inpatient care" cluster market for hospital services defined in the recent FTC cases is not appropriate when hospitals have significant actual or potential competition from free standing surgical or emergency room facilities, ${ }^{223}$ or when nonhospital providers of outpatient services could readily serve additional patients presently obtaining medical care from hospitals. ${ }^{224}$ Similarly, commentators identify the rise of new financial institutions offering some but not all the services of commercial banks as a reason for replacing the cluster approach with the DOJ Guidelines substitutability methodology in defining product markets for bank services. ${ }^{225}$

When cluster markets are defined by applying this pragmatic rationale, the underlying principle behind market definition remains the substitutability analysis of the DOJ Guidelines. Hence, when new substitutes in demand or supply become available, the cluster market must give way to product markets defined by each service and its substitutes. In future hospital merger cases, in consequence, services for which hospitals face competition from non-hospital providers will likely merit separate product markets. ${ }^{226}$ However, cluster markets may continue to be appropriate for those limited groups of services offered exclusively by hospitals, ${ }^{227}$ especially when all hospitals offer them in similar shares, or when data limitations prevent market share computations by individual services. ${ }^{228}$

222. Approaching the competitive analysis market by market may also suggest a curative divestiture that would not be apparent if competition is analyzed solely within the cluster. See infra note 341 and accompanying text (fix-it-first policy).

223. American Medical Int'l, 104 F.T.C. 1, 193 (1984).

224. Hospital Corp. of Am., 106 F.T.C. 361,465 n.6 (1984), aff d 807 F.2d 1381 (7th Cir. 1986), cert. denied, 55 U.S.L.W. 3746 (1987). Cf. id. at 466 ("It may well be that in this case the proper product market excludes all outpatient care; perhaps outpatient care should be a separate relevant market or markets.").

225. See Horizontal Mercers, supra note 35, at $75 \mathrm{n} .369$ (collecting commentary questioning whether cluster markets remain appropriate in the financial services sector "after two decades of evolution").

226. Cf. Proger, supra note 153, at 619 ("“[A]s more evidence becomes available about the emerging forms of new competition in health care and about their substitutability with hospital based services, relevant product market definition in hospital cases will take into account these new forms of competition.").

227. Cf. Proger, supra note 153, at 621 ("[T] services for which there are no non-hospital substitutes. But not all services provided by a hospital are within that core.").

228. Even if large clusters continue to appear justified, it would be inappropriate to place secondary inpatient care services and tertiary inpatient care services in the same cluster because all hospitals do not offer both types of patient care in the same market shares. This is evident from the observations that the geographic markets for tertiary care services are generally much larger than the geographic markets for secondary care services, see infra note 237 and accompanying text, and that some hospitals offering secondary care services are unable to offer tertiary care. 


\section{Geographic Market Definition.}

a. Application of the DOJ Guidelines to hospitals. The DOJ Guidelines approach to market definition identifies the geographic market in which a merging hospital producing a relevant product competes similarly to the way it defines the product market. Under the DOJ Guidelines, geographic market definition begins with the location of each merging hospital or each facility of a multi-hospital entity. The DOJ Guidelines ask whether a hypothetical monopolist of each relevant product at that location would find it profitable to raise the product's price significantly. If not, the location of a nearby actual or potential competitor in the product market is added to the proposed market and the question is repeated. Increasingly distant locations are incorporated in the provisional market until a geographic area is identified in which a hypothetical cartel selling a given relevant product would be able to raise price a significant amount without unprofitably losing many patients to actual or potential competitors outside the area. This region is the smallest relevant geographic market associated with a given relevant product market. ${ }^{229} \mathrm{~A}$ different geographic market may correspond to each separate relevant product market.

As with product market definition, the DOJ Guidelines approach to geographic market definition takes into account both demand and supply substitutability. ${ }^{230}$ A proposed geographic market is too small so long as a

229. See 1984 Merger Guidelines, supra note $51, \S 2.3$.

For antitrust analysis, the DOJ Guidelines market definition algorithm is superior to the geographic market definition methodology described in Garnick, Luft, Robinson \& Tetreault, Appropriate Measures of Hospital Markel Areas, 22 Health Services Res. 69, 73 (1987). These authors incorporate an outside hospital into their provisional geographic market so long as a significant fraction of patients substitute care at that more distant hospital for care at any single hospital within the proposed market. This algorithm will lead to markets that are broader than those of the DOJ Guidelines because this test is much easier for a distant hospital to meet than the DOJ Guidelines standard for inclusion. Under the DOJ Guidelines methodology, more distant hospitals are added to the proposed market only if the number of customers who would substitute any outside hospital, the marginal patients, is a large fraction of the patients collectively served by all the hospitals within the proposed market. Only then will distant hospitals collectively provide a competitive brake on cartel pricing within the provisional geographic market, so only then must one or more distant hospitals be added to the relevant market. Under the Garnick et al. methodology, the proposed market will instead be expanded if the number of marginal patients is a large fraction of the patients served by any one of the hospitals within the proposed market, namely the hospital from which in large part they switch. In consequence, some hospitals included in the resulting market could be excluded without jeopardizing a cartel's ability to collude successfully.

The Guidelines algorithm is also superior for antitrust analysis to a second methodology proposed by these authors that identifies the competitors of a given hospital as all hospitals within an arbitrary 5 or 15 mile radius around it. Garnick, Luft, Robinson \& Tetreault, supra, at 69. This approach ignores physical features of geography, population distributions, and other factors affecting patient substitution patterns. Hence the resulting geographic markets may bear no relation to areas within which collusive arrangements might occur.

230. The one geographic cluster market defined by the Supreme Court, in Grinnell, 384 U.S. 521 , can be rationalized on pragmatic grounds consistent with the substitutability concerns of the DOJ Guidelines. See supra notes 214-20 and accompanying text. Complementarity is not an issue for geographic market definition, unlike product market definition. Under a supply complementarity rationale for product cluster markets, a geographic cluster market could in principle be defined for multi-hospital chains if scope economies across multi-plant firms are substantial. Such a market would be analogous to product cluster markets based on scope economies. However, geographic 
substantial fraction of patients would purchase hospital services from firms at locations outside the initially defined area if prices rose slightly at nearby hospitals. The market need no longer expand when a sufficient number of patients would pay a high collusive price rather than bear the costs of traveling for health care to locations outside the boundaries of the hypothetical cartel, ${ }^{231}$ for then a cartel within the region would be profitable. In general, the larger the geographic region, the fewer the number of customers who will consider locations outside the region where the relevant product is sold to be demand substitutes for locations within the region. As a result, the larger the region, the less the threat that new competition located outside the region will compete away the monopoly profits of the hypothetical cartel.

Perhaps the most important factor limiting the geographic scope of markets for the services offered by hospitals is the unwillingness of patients to patronize hospitals far from their residences. ${ }^{232}$ Often, the longer the distance a patient must travel, the farther his friends and relatives must also travel to visit him and the farther his physicians must travel. Further, long distances between home and hospital are disfavored because a patient may be forced by physician affiliations to switch doctors if he wishes to select a distant hospital. ${ }^{233}$ Indeed, to the extent the physician is the patient's agent in advising on health care choices, physician preferences and affiliation are likely

scope economies fail to approach in magnitude the scope economies at issue in product markets, and in any event complementarity is an unsatisfactory basis for market definition.

231. It is not possible to quantify the critical fraction of patients unwilling to switch locations without knowing the demand curves facing the two groups and the cost function for the hypothetical cartel. Thus, survey data on the propensity of customers to switch hospitals as relative prices change can be suggestive but not conclusive concerning the extent of geographic markets. Cf. supra note 142 and accompanying text (comparable issue for product market definition); Baker \& Bresnahan, The Gains from Merger or Collusion in Product-Differentiated Industries, 33 J. Indus. EcoN. 427 (1985) (market power of sellers in product differentiated industries depends upon fraction of inframarginal customers).

Further, surveys describing pre-merger behavior can be misleading as evidence of demand substitution predilections. If the market is competitive prior to the merger, few patients will have reason to travel to distant locations, so surveys of actual substitution patterns will show patient substitution to be low. Yet many of these patients would be willing to travel to avoid $5 \%$ price increases by nearby hospitals. See supra note 134 (Cellophane trap); infra notes 241-42 and accompanying text (hospital patient-flow data).

232. McGuirk \& Porell, Spatial Patterns of Hospital Utilization: The Impact of Distance and Time, 21 INQUIRY 84, 86 (1984).

233. A patient is likely to select a specialist in his community, if one acceptable to his primary care physician is available, for similar reasons of minimizing transportation costs. Through this mechanism, patient hospital preferences may be taken into account in choice of physician. McGuirk \& Porell, supra note 232, at 86. Similarly, if HMO's have limited hospital affiliations, a patient will factor both travel time and insurance premium into his selection of health care provider, and thus, choice of hospital.

Further, if some hospitals raise the price of a hospital service, doctors may alter their hospital affiliations, admitting patients to lower priced hospitals (or employing ambulatory care clinics) instead of hospitals whose prices have increased. Indeed, doctors can be expected to consider the price of hospital services in making recommendations to patients, to the extent hospitals and doctors compete for patient rents and joint (health care) demand is elastic. Cf. supra note 199. 
to count strongly in the patient's decision. ${ }^{234}$ Not surprisingly, doctors prefer to obtain affiliations and admit patients into hospitals located near the doctor's office. ${ }^{235}$ Similarly, third party payers (health insurers) may create financial incentives for patients to favor hospitals in a narrow geographic area, thereby limiting the scope of geographic markets. ${ }^{236}$

Patient substitution preferences vary across hospital services. To obtain some hospital services, primarily the specialized services offered by "tertiary" care providers, many patients will travel long distances. Therefore, the geographic markets for such services are likely to be larger than the geographic markets for primary and secondary care services. ${ }^{237}$

b. Patient flow statistics. Geographic market definition in the extant hospital merger opinions has been based primarily upon patient flow statistics, the most readily available information on geographic competition. This methodology applies in the hospital context the Elzinga-Hogarty approach to geographic market definition, under which geographic markets are identified based on shipment patterns of the products at issue. ${ }^{238}$ Under this methodology, the geographic market is expanded until two tests are simultaneously satisfied: The firms within it must account for most of the shipment inside the candidate region, and those firms must do most of their business inside the candidate region. In the hospital industry, patient flow is the analogue of shipments. Thus a geographic market for a given product

234. Hospital Corp. of Am., 106 F.T.C. 361,467 (1985), aff'd, 807 F.2d 1381 (7th Cir. 1986), cert. denied, 55 U.S.L.W. 3746 (1987); American Medical Int'l, 104 F.T.C. 1, 197 (1984); McGuirk \& Porell, supra note 232, at 84,86 . The Department of Justice relied on this observation in defining the geographic market it alleged in a recently litigated hospital merger case. It pointed to the narrow geographic spread of physician privileges and the resulting patient admitting practices as evidence for a narrow geographic market. Rockford, No. 88-C-20186, slip op. at 28-29 (N.D. Ill. Feb. 23, 1989), appeal filed.

235. See Garnick, Luft, Robinson \& Tetreault, supra note 229, at 69, 72.

236. See Rockford, No. 88-C-20186, slip op. at 29-30 (N.D. Ill. Feb. 23, 1989), appeal filed.

237. Rule, supra note 115, at 127. See Hospital Corp. of Am., 106 F.T.C. at 468. This observation creates a problem for geographic market definition if the product market is defined based upon the cluster of services approach. In Hospital Corp. of $A m$., the FTC chose to ignore the broad tertiary care service areas, and defined geographic markets based primarily on patient flows for secondary care. This was probably the best choice given that the cluster approach to product definition was employed, because the Commission's primary competitive concern was with the potential for collusion among secondary care providers. However, if individual secondary and tertiary care services form separate product markets, each can have a different geographic market. See supra note 228.

238. Elzinga \& Hogarty, The Problem of Geographic Market Delineation in Antimerger Suits, 18 Antitrust Bull. 45 (1973) [hereinafter Elzinga \& Hogarty, Antimerger Suits]; Elzinga \& Hogarty, The Problem of Geographic Market Delineation Revisited: The Case of Coal, 23 ANTITrust BulL. 1 (1978) [hereinafter Elzinga \& Hogarty, The Case of Coal]; see HorizonTal Mercers, supra note 35, at 96-101.

A related methodology from the health policy literature defines hospital market areas for hospital planning purposes based on patient flow, whether determined from hospital admissions and discharges, see Garnick, Luft, Robinson \& Tetreault, supra note 229, at 69, 73, or vital statistics mortality data, see Carpenter \& Plessas, Estimating Hospital Service Areas Using Mortality Statistics, 20 Health Services Res. 19 (1985). This literature attempts to explain hospital admissions by distance from the patient's community, controlling for demographic characteristics, medical care requirements, and the distance to alternative hospitals. McGuirk \& Porell, supra note 232, at 84, 8586. 
market is identified when the hospitals in the region serve most of the patients using the services in the product market who originate in that region, and when most of the hospital patients seeking the services in the product market come from that region. ${ }^{239}$

Several difficulties with the Elzinga-Hogarty approach have been identified. Geographic market definition based on actual patterns of customer association with firms can either be underinclusive or overinclusive relative to the regions that the DOJ Guidelines would delineate. ${ }^{240}$ On the one hand, defining markets for hospital services based on patient flow can understate the geographic regions relevant for antitrust merger analysis. This difficulty arises because the hospital choices patients actually make are based on current prices. Yet, if a hospital cartel consisting only of hospitals actually patronized were to increase price, enough patients may shift to hospitals slightly farther away, not currently patronized, to defeat the price increase. ${ }^{241}$ In short, potential competitors must be included in the relevant geographic market for merger analysis but these firms will not be identified by patient flow data. ${ }^{242}$

On the other hand, markets based on patients flows may overstate the geographic markets relevant to antitrust merger analysis when the product market includes hospital services that are not perfect substitutes. In this case, those patients with strong preferences for obtaining services at distant hospitals-such as many tertiary care patients or patients desiring higher quality care than is available locally-will travel there, even if most patients are unwilling to travel. ${ }^{243} \mathrm{~A}$ hospital market that includes these distant institutions will therefore encompass a region larger than the smallest region

239. Technically, the market is expanded until the LIFO (little in from outside) and LOFI (little out from inside) statistics are small. To apply this test to hospital markets, it is necessary to calculate the fraction of hospital patients from a particular region who are admitted to hospitals outside the region (to test whether the LOFI requirement holds) and the fraction of patients admitted to hospitals inside the region who originate outside the area (to see if LIFO holds). See Hospital Corp. of $A m$., 106 F.T.C. at 468 n.7. Elzinga and Hogarty have variously argued that these tests are met for a proposed area when the LIFO and LOFI fractions fall below 25\%, Elzinga \& Hogarty, Antimerger Suits, supra note 238, at 45, 74-75, and when they fall below $10 \%$, Elzinga \& Hogarty, The Case of Coal, supra note 238 , at $1,2$.

240. Werden, Market Delineation and the Justice Department's Merger Guidelines, 1983 DukE L.J. 514 , 576 [hereinafter Werden, Market Delineation]; Werden, The Use and Misuse of Shipments Data in Defining Geographic Markets, 26 Antitrust Bull. 719 (1981) [hereinafter Werden, Shipments Data]; Scheffman \& Spiller, Geographic Market Definition Under the U.S. Department of Justice Merger Guidelines, 30 J.L. \& ECon. 123, 129 (1987).

241. Similarly, hospitals in the neighborhood of colluding hospitals yet not offering the services defined by the relevant product market may respond to the higher cartel price by introducing new services, and thereby inducing patients to depart from their current hospital choices.

242. One recent study in the health policy literature recognizes this antitrust criticism of the patient origin approach. "One limitation of a direct measurement of demand for hospital services is inclusion only of institutions that currently provide care. For many issues, it is important also to include potential competitors-that is, hospitals that could obtain the equipment and staff to begin to compete for certain sets of patients (for example, by adding a heart surgery program)." Garnick, Luft, Robinson \& Tetreault, supra note 229 , at $69,71$.

243. Werden, The Limited Relevance of Patient Migration Data in Market Delineation for Hospital Merger Cases, J. Health Econ. (forthcoming) [hereinafter Werden, Patient Migration]; Ordover \& Willig, The 1982 Department of Justice Merger Guidelines: An Economic Assessment, 71 Calif. L. Rev. 535, $551-52$ 
in which a hospital cartel could successfully collude. This difficulty may be particularly serious when product markets are defined based on the cluster of services methodology, rather than when product markets are more finely partitioned based on the DOJ Guidelines methodology. ${ }^{244}$

Once these criticisms of geographic market definition based on patient flow are recognized, market boundaries can readily be adjusted to account for them. The first adjustment avoids underinclusion. Hospitals outside the region of current patient flow need not be considered potential competitors and included in a broadened geographic market if evidence of patient travel preferences, Qbtained independently from patient flow statistics, ${ }^{245}$ establishes that the outside hospitals would not be turned to for medical care in the event that the currently patronized hospitals were to collude and raise prices. Because it is typically costly for patients to patronize distant hospitals, however, it will rarely be necessary to expand the market beyond the area of current patient choice.

The second adjustment avoids overinclusion. Distant hospitals can be excluded from the market even if a fraction of patients from the market obtain care there, so long as those patients traveling long distances obtain qualitatively different services from the services available nearby. Thus, if patients leave the region only for specialized treatment at tertiary care hospitals, those facilities and other hospitals equally distant can be excluded from the geographic market if the product market involves less specialized services. ${ }^{246}$ With these two adjustments, patient flow statistics will allow the identification of the relevant geographic market as defined by the DOJ Guidelines. ${ }^{247}$

(1983); Werden, Market Delineation, supra note 240, at 514, 576; Werden, Shipments Data, supra note 240, at $719,725-26$.

Patient origin data may also overstate the size of the relevant geographic market if the more distant hospitals operate at full capacity. Capacity constrained hospitals will be unable to expand output to compete away the price increase created by the other hospitals in the area with excess capacity, so may be excluded from a cartel without jeopardizing collusive profits.

Further, the ability of a monopolist to practice geographic price discrimination can lead the Elzinga-Hogarty approach to underestimate the geographic market because there will be "significant exports of a product from an area even though that product and area are a market under the Guidelines." Werden, Market Delineation, supra note 240, at 514, 576.

244. See infra note 258 and accompanying text (adjustment in Hospital Corp. of Am. Ior this problem).

245. See infra note 249 and accompanying text (adjustment in American Medical Int'l for this problem).

246. Similarly, patient inmigration from surrounding regions to hospitals in a city will often substantially exceed patient outmigration from the city to more distant hospitals because of the higher perceived quality of city hospitals. Werden, Patient Migration, supra note 243. Under such circumstances, geographic market definition can be based exclusively on outmigration data to avoid overinclusion. See infra note 262. Alternatively, one study employing patient flow data attempts to avoid overinclusion by excluding patient cases with high DRG weights, thought to represent those patients requiring the most specialized care. Morrisey, Sloan \& Valvona, Defining Geographic Markets for Hospital Care, Law \& Contemp. Probs., Spring, 1988, at 165, 179-80, 185-86.

247. Alternatively, one might identify geographic markets pursuant to the DOJ Guidelines methodology by estimating residual demand curves. Scheffman \& Spiller, supra note 141, at 123. However, the necessary data may be unavailable. 
In its recent hospital merger decisions, the Federal Trade Commission used patient flow statistics to define the geographic markets, while making adjustments in order to avoid the overinclusion and underinclusion problems. In both American Medical International and Hospital Corp. of America, the Commission defined geographic markets for its acute inpatient care product market clusters. The geographic market in American Medical International, the California region comprised of San Luis Obispo County and the City of San Luis Obispo, was defined primarily based on statistics describing patient "in flow" and patient "outmigration." 248 However, the FTC confirmed that this market did not exclude more distant potential competitors by observing that its market definition was also supported by "geographic barriers (patient convenience and limited mobility, location of admitting physician)."249 The resulting market excluded a hospital located twenty-five miles from the city of San Luis Obispo. ${ }^{250}$

In Hospital Corp. of America, the Commission recognized that a geographic market must be expanded beyond the region of those hospitals currently selected by patients to include significant potential competitors. ${ }^{251}$ However, the FTC was forced to adopt the Chattanooga, Tennessee, urban area as its geographic market because the region was accepted by the parties to the case and there was insufficient factual evidence from which to define the extent of a broader market. ${ }^{252}$ The Commission nevertheless recognized the need to avoid overinclusion in its market definition by ignoring distant patient travel to obtain specialized, tertiary care when it interpreted patient flows. ${ }^{253}$

A recent federal district court decision in a hospital merger case relied extensively upon patient flow statistics to define the geographic market as a three-county area (plus small parts of two other counties) around Rockford, Illinois. ${ }^{254}$ The court recognized that geographic markets for tertiary services

248. American Medical Int l, 104 F.T.C. at 195-96.

249. Id. at 196. The Commission also argued that its geographic market definition was supported by industry recognition of competitive regions. See id. at 196, 197.

250. Id. at 197

251. Hospital Corp. of Am., 106 F.T.C. at 466, 471-72.

252. Id. at 472. The accepted urban area is comprised of one Tennessee county and three adjoining Georgia counties. The Commission rejected complaint counsel's proposed broader market on the ground that there was no credible basis for adding the regions proposed, in which many of the hospitals were managed by respondent, without adding other areas equally distant from Chattanooga, in which other parties owned and managed the hospitals. Id. at 470 . This market excluded a number of hospitals located within a 45-minute driving radius of Chattanooga. See id. at 463-64.

253. Id. at 468. See United States v. Carilion Health System, 707 F. Supp. 840, 844, 848 (W.D. Va. 1989) (larger geographic market for tertiary care than for primary and secondary care services), appeal fled, No. 89-2625 (4th Cir. 1989); cf. American Medical International, 104 F.T.C. at 196-97 (patient flow statistics vary with the service rendered).

254. United States v. Rockford Memorial Corp., No. 88-C-20186, slip op. at 32-68 (N.D. Ill. Feb. $23,1989)$, appeal filed. The court defined a geographic market such that "the defendants compete with four other hospitals for the group of patients representing about $90 \%$ of the admissions of the defendants." Id. at 67 . Because there was little difference in the LIFO and LOFI statistics across alternative geographic market proposals, id. at 54-55, the court chose the smallest area satisfying the Elzinga-Hogarty test. Id. at 56. Moreover, there was little variation between patient flow statistics computed from admissions data and statistics computed from discharges data. Id. at 47. Cf. Carilion, 707 F. Supp. 840, 848 (W.D. Va. 1989) (broadening market beyond the immediate vicinity of 
were broader than those for primary and secondary care, so it ignored competition from tertiary care providers. ${ }^{255}$ Similarly, the court discounted patient travel from outside the metropolitan area because a majority of the distant patients were attracted by the opportunity to obtain specialized service unavailable in their local hospitals. ${ }^{256}$

Older hospital merger decisions, written prior to the promulgation of the 1982 Guidelines, ${ }^{257}$ have relied on the political boundaries of Health Service Areas as a basis for geographic market definition. ${ }^{258}$ This approach is unlikely to be employed today, except insofar as patient flow statistics may be kept in terms of these regions, because these areas bear no apparent relation to competitive conditions or the substitutability considerations of the DOJ Guidelines. ${ }^{259}$

Even taking into account the potential competition from hospitals not currently serving the patients of a local area, courts have generally concluded that geographic markets for most hospital services are small. For most hospital services, courts typically delineate markets no larger than a metropolitan area or the county surrounding a city, except for the specialized care available at teaching hospitals, for which geographic markets are thought to be broader. ${ }^{260}$ The geographic market was the San Luis Obispo area in American Medical International, the Chattanooga area in Hospital Corp. of America, and the New Orleans area in Hospital Affiliates. ${ }^{261}$ Moreover, a recent systematic study of geographic markets is consistent with the view that the metropolitan area should be the size of a typical market for secondary care

Roanoke, Virginia, to include surrounding counties based on patient flow statistics), appeal fled, No. 89-2625 (4th Cir. 1989).

255. Rockford, No. 88-C-20186, slip. op. at 62-63, appeal filed.

256. Id. at 33-38, 65. Patient inmigration statistics should also be discounted if distant patients are attracted by the opportunity to obtain better care than their local hospitals would provide. Werden, Patient Migration, supra note 243.

257. 1982 Merger Guidelines, supra note 51.

258. United States v. Hospital Affiliates Int'l, Inc., 1980-81 Trade Cas. (CCH) 963,721 , at 77,853 (E.D. La. 1980) (geographic market of New Orleans and surrounding areas); American Medicorp. v. Humana, Inc., 445 F. Supp. 589, 604 (E.D. Pa. 1977). However, the court in Hospital Affliates supported its decision based upon the location of most psychiatrist's offices and patient flow statistics. Hospital Affliates, at 77,852-53.

259. See Hospital Corp. of Am., 106 F.T.C. at 471; but see Schramm \& Renn, Hospital Mergers, Market Concentration and the Herfindahl-Hisrchman Index, 33 EмоRу L.J. 869, 873 (1984).

260. See Rule, supra note 115, at 127 ("In most cases the geographic market [for hospital services] will be highly localized."); $q$. United States v. National Medical Enter., 1987-1 Trade Cas. (CCH) I 67,640 (E.D. Cal. 1987) (Modesto area geographic market, roughly one county) (consent judgement). Courts defining geographic markets in non-merger antitrust cases involving hospital services have defined markets of similar small size. Jefferson Parish Hosp. Dist. No. 2 v. Hyde, 466 U.S. 2 (1984) (New Orleans metropolitan area); Seidenstein v. National Medical Enter., 769 F.2d 1100, 1106 n.l (5th Cir. 1985) (city of El Paso); Weiss v. York Hosp., 745 F.2d 786, 825 (3d Cir. 1984) (most of York County, Pennsylvania), cert. denied, 470 U.S. 1060 (1985); but see Robinson v. Magovern, 521 F. Supp. 842, 881 (W.D. Pa. 1981) (16-county geographic market in three states surrounding Pittsburgh), aff'd, 688 F.2d 824 (2d Cir.), cert. denied, 459 U.S. 971 (1982).

261. See also Rockford, No. 88-C-20186, slip op. at 32-68 (N.D. Ill. Feb. 23, 1989) (three-county area around Rockford, Illinois with roughly a 30 -mile radius), appeal fled; but of. Carilion, $707 \mathrm{~F}$. Supp. 840, 847-48 (W.D. Va. 1989) (19-county market around Roanoke, Virginia, for primary and secondary services with roughly a 50-mile radius; much larger market for tertiary care services), appeal filed, No. 89-2625 (4th Cir. 1989). 
services in urban regions, although its authors interpret the results as demonstrating that geographic markets are broader than Standard Metropolitan Statistical Areas (SMSA's). ${ }^{262}$ This study also suggests that the typical rural market might have a radius no larger than fifty miles. ${ }^{263}$

The delineation of geographic markets is likely to be contested because the hospital industry is often highly concentrated within SMSA's, while not concentrated within broader regions. ${ }^{264}$ In consequence, geographic market definition can be expected to determine the outcome of many hospital merger cases.

262. Morrisey, Sloan \& Valvona, supra note 246, at 175-88. This study of hospital concentration in Birmingham, Omaha, Philadelphia, and Phoenix found that residents of each SMSA seldom left their metropolitan area for inpatient care. In three of these cities many treated cases came from outside the SMSA, so a strict application of the Elzinga-Hogarty approach to geographic market definition would require expanding the market beyond the SMSA. (For Philadephia, patient inflows were more limited.)

However, some urban hospitals likely provide better care than most or all rural hospitals in these regions, and thus likely offer a superior product. For example, of the 44 hospitals in a broadly defined Washington, D.C., metropolitan area, eleven were rated of superior quality by one consumer group (and five could not be rated). Hospitals, 6 Washington Consumers' Checkbook 13, 20-21 (1987). All but one of the 11 high quality hospitals were within Washington's city limits or its closein suburbs. (The exception, Johns Hopkins, is a tertiary care provider in Baltimore.) Five out of 14 hospitals within city limits were rated top quality, while only two hospitals were found high quality of the 11 rated for the Virginia suburbs. This evidence suggests that even if the flow of rural patients into urban hospitals is large, these patients are among those likely to have the most inelastic demand for urban care. Cf. Rockford, No. 88-C-20186, slip. op. at A30 (N.D. Ill. Feb. 23, 1989) (finding of fact 120) (most patients who travel to Rockford, Illinois, hospitals from out of town come "to receive services that are not available at the hospitals closest to them" or "because they believe that the Rockford hospitals provide higher quality."), appeal fled.

Under these circumstances, geographic markets for urban hospitals will be more narrow than the area from which patients are drawn. See generally Werden, Patient Migration, supra note 243. Hence, the more narrow area of patient outflows is likely to provide a better indicator of geographic market bounds than the area of patient inflow. But of. Rockford, No. 88-C-20186, slip. op. at 54-55 (N.D. Ill. Feb. 23, 1989) (LIFO statistic is greater than LOFI in narrow geographic market), appeal fled. Although the authors attempt to control for this difficulty with a measure of case complexity, their measure at best controls for whether rural patients are obtaining specialized tertiary care services in urban areas, and not for the relative quality of urban versus rural hospital care

263. Morissey, Sloan \& Valvona, supra note 246, at 190-9I. Based on evidence from patient flows in rural Nebraska counties, the authors conclude that typical markets extend six counties, generally reaching to include the nearest urban area. As the typical Nebraska county with one or two hospitals has no more than 1000 square miles, U.S. DeP'T of Commerce, Bureau of the Census, County and City Data Book 340, 342, 354, 356 (1983), a four-to nine-county region might have a radius of 35 to 55 miles. If local hospitals do not offer close substitutes for more specialized care available in urban areas, then these aggregate statistics suggest that rural markets may be smaller than six counties for primary care.

Similarly sized markets defined by patient flows were found in a recent study of hospital markets in the six New England states. Wennberg \& Gittelson, Variations in Medical Care among Small Areas, 246 Sci. Am., Apr. 1982, at 120. Wennberg and Gittelson identify 193 hospitals areas in these states as regions "whose residents were most likely to go to a particular community to be treated." The typical market area defined for Vermont, a largely rural state, has a radius of less than 50 miles. A companion study of Iowa identified over 100 markets. Wennberg, Dealing With Medical Practice Variations: A Proposal for Action, Health Affs., Summer 1984, at 6, 16.

264. See infra note 285 and accompanying text. Cf. Werden, Patient Migration, supra note 243, at note 13 (hospital mergers in small cities far from large cities raise the greatest competitive concern). 


\section{Concentration Measures}

Courts and antitrust enforcers compute market shares in order to determine concentration and the increase in concentration resulting from a merger in a relevant market. When concentration rises, collusion becomes more likely because the fewer the number of firms, the easier it is for them to coordinate a reduction in industry output and to monitor and police cheating. ${ }^{265}$ Thus, a high level of concentration creates a rebuttable presumption of anticompetitive effect. ${ }^{266}$

The available data often do not permit government enforcers and courts to choose the units in which concentration is measured. ${ }^{267}$ When a choice of units is possible, it is usually between an output measure and a capacity measure. ${ }^{268}$ For example, in an acute inpatient hospital care product cluster market, the number of hospital beds available is a measure of hospital capacity while the number of patient days or total patient revenues measures hospital output. 269

The DOJ Guidelines suggest that when a choice can be made, output measure should be used to compute concentration for markets involving differentiated products, while capacity measured should be employed to compute concentration for markets involving homogeneous goods. ${ }^{270}$ In the recent hospital merger decisions, however, neither the Federal Trade Commission nor the courts have discovered significant practical difference among the various measures for determing the competitive significance of hospitals within acute care inpatient cluster markets. ${ }^{271}$ If instead individual services constitute product markets, it is likely that the number of patients, an

265. See supra notes 121-25 and accompanying text. Adjustments to the inferences of market power derived from market shares are considered infra notes 286-336 and accompanying text (facilitating factors).

266. United States v. General Dynamics Corp., 415 U.S. 486, 498 (1974) (presumption rebutted by non-market share evidence); United States v. Philadelphia Nat'l Bank, 374 U.S. 321,363 (1963).

267. 1984 Merger Guidelines, supra note 51, $\$ 2.4$.

268. See generally Horizontal Mergers, supra note 35, at 153-161.

269. Hospital Corp. of Am., 106 F.T.C. 361, 487 (1985), aff d, 807 F.2d 1381 (7th Cir. 1986), cert. denied, 55 U.S.L.W. 3746 (1987).

270. 1984 Merger Guidelines, supra note 51, $\$ 2.4$. Firm capacity measures the competitive significance of producers of homogeneous goods because each firm can readily expand production to the limits of capacity. However, when goods are differentiated, firms may be unable to increase sales even if additional units can be produced at low marginal cost. In this case, firm output rather than capacity is likely the better measure of competitive significance. This adjustment is rough at best. Other ways of taking into account the significance of product differentiation are discussed supra notes 133-35 and accompanying text (direct competition). The role of excess capacity as a factor frustrating collusion is considered infra note 319 and accompanying text, and its role as a barrier to entry is considered infra note 302 and accompanying text.

271. Hospital Corp. of Am., 106 F.T.C. at 487 (beds, inpatient days, and patient revenues); American Medical Int'1, 104 F.T.C. 1, 201 \& n.11 (1984) (inpatient days and revenues); United States v. Hospital Affiliates In'l, Inc., 1980-81 Trade Cas. (CCH) I 63,721 (E.D. La. 1981) (beds and patient days); Rockford, No. 88-C-20186, slip op. at 72-73 (N.D. Ill. Feb. 23, 1989) (beds, inpatient admissions, and inpatient days), appeal filed. 
output measure, will be the only information available from which to estimate market shares. ${ }^{272}$

Hospital management contracts raise a question for the calculation of market shares: Should separately owned hospitals managed by the same firm be aggregated in the market share calculation? In Hospital Corp. of America, the FTC treated commonly managed hospitals as an aggregate entity in determining firm market shares. The Commission recognized that commonly managed firms have a reduced incentive to compete independently and thus have an increased incentive to coordinate output reductions and price increases. ${ }^{273}$ This argument would seem equally applicable to contracts among nonprofit hospitals. ${ }^{274}$

The DOJ Guidelines measure concentration in the relevant market with the Herfindahl-Hirschman Index (HHI), derived by summing the square of firm market shares. ${ }^{275}$ The Department of Justice has attempted to create bright line standards to identify concentration levels and increases which create a dangerous likelihood of collusion. In particular, the Justice Department is likely to challenge acquisitions which lead to post-merger HHI's above 1800 if the HHI increase exceeds 50, or acquisitions which lead to post-merger HHI's above 1000 if the HHI increase exceeds 100.276

Courts use similar standards to evaluate the anticompetitive significance of market concentration, whether those standards are expressed in terms of HHI's or four-firm concentration ratios. ${ }^{277}$ In American Medical International

272. See Robinson v. Magovern, 521 F. Supp. 842, 884-86 (W.D. Pa. 1981) (market shares based on number of adult open heart surgery patients) (monopolization claim), aff'd, 688 F.2d 824 (2d Cir.), cert. denied, 459 U.S. 971 (1982).

273. Hospital Corp. of Am., 106 F.T.C. at $476-78$ \& 477 n.13. After finding a violation of the antitrust laws in this case, the FTC ordered a curative divestiture of a hospital management contract as well as the divestiture of two hospitals. Id. at 521. See Bresnahan \& Salop, Quantifying the Competitive Effects of Production Joint Ventures, 4 INT'L J. Indus. ORG. 155 (1986); cf. Rockford, No. 88-C20186 , slip op. at 73 (N.D. Ill. Feb. 23, 1989) (calculating concentration both taking into account and not taking into account affiliation by management contract and through common ownership by a religious order), appeal fled.

274. Nonprofit firms with common managements are unlikely to have different objectives. See supra note 96 and accompanying text.

275. 1984 Merger Guidelines, supra note $51, \S 3.1$

276. Id. § 3.11. However, in the second term of the Reagan Administration the Department of Justice has effectively raised the 1000 threshold to at least 1600. Baxter, Counseling Your Client on Monopolization, Mergers and Joint Ventures, 55 AntrTrust L.J. 321, 328 (1986); cf. Krattenmatter \& Pitofsky, Antitrust Merger Policy and the Reagan Administration, 33 Antrtrust Bull. 211 , 226-27 (1988).

Acquisitons are also likely to be challenged if they satisfy the "leading firm proviso" of the DOJ Guidelines, which frowns upon the acquisition of a $1 \%$ competitor by any firm with a $35 \%$ or greater market share. 1984 Merger Guidelines, supra note 51, § 3.12.

The empirical evidence connecting concentration with collusion is ambiguous, and the critical concentration levels selected for increased antitrust scrutiny appear influenced at least as much by precedent and a desire for a bright line standard as by economic learning. $C f$. Horizontal Mergers, supra note 35, at 182-89 (reviewing economic studies). However, it is difficult to suggest any generally applicable superior alternative to relying on concentration as an indicator of collusive potential, and the critical concentration levels currently employed are not implausible. But of. Bresnahan, supra note 47 (surveying new empirical techniques for measuring market power).

277. The Federal Trade Commission measured concentration in Hospital Corp. of Am. using three statistics: the two-firm concentration ratio, the four-firm concentration ratio, and the HHI. Hospital Corp. of Am., 106 F.T.C. at 487-89. In most cases, all measures of concentration will lead to similar 
the Federal Trade Commission proscribed a merger which raised the HHI from 3818 to $6025 .^{278}$ The FTC found a violation of Clayton Act section 7 when the HHI rose approximately 400 points to exceed 2400 in the acquisitions considered in Hospital Corp. of America. ${ }^{279}$ A federal court has prohibited a hospital merger that raised the HHI from the 2,500 to 3,000 range to the 4,600 to 5,600 range. ${ }^{280}$

By these standards, hospital markets generally appear concentrated if the typical geographic market is a metropolitan area. ${ }^{281}$ One study computed HHI statistics by hospital diagnosis, ${ }^{282}$ for the Columbia, South Carolina, metropolitan area (SMSA), and for Orangeburg County, a rural region with one general hospital. ${ }^{283}$ In both cases, HHI's typically exceeded 2000.284 Another study computed concentration levels for 336 urban areas. It found that the vast majority of HHI statistics exceeded 1800 if the geographic markets were metropolitan areas. ${ }^{285}$ In combination with the high reported concentration levels in the extant sample of hospital merger antitrust cases, these results suggest that many if not most hospital mergers will be subject to a high level of scrutiny by the courts and antitrust enforcers.

conclusions for a given relevant market. See Horizontal Mergers, supra note 35, at 181-82; see generally id. at 175-201.

278. American Medical Int l, 104 F.T.C. at 201. In a narrower geographic market, the HHI increased from 4,370 to 7,775. With market shares based on revenues rather than inpatient days, the increase in the HHI was from 3,518 to 5,507 in one geographic market, and from 3,996 to 7,097 in the other. Id. at 201 n.12.

279. Hospilal Corp. of Am., 106 F.T.C. at $487-88$.

280. Rockford, No. 88-C-20186, slip op. at 73 (N.D. Ill. Feb. 23, 1989), appeal filed.

281. Cf. Rule, supra note 105, at 127-28 (hospital markets in towns and smaller cities typically have HHI's exceeding 1800, while HHI's below 1800 may be observed in large metropolitan areas). A similar conclusion arises from reviewing market concentration in non-merger antitrust cases involving hospitals. In Robinson v. Magovern, 521 F. Supp. 842, 878 (W.D. Pa. 1981) (refusal to deal and monopolization claims), aff'd, 688 F.2d 824 (2d Cir.), cert. denied, 459 U.S. 971 (1982), the court found that six hospitals offered adult heart surgery in the Pittsburgh area. The HHI for this market must equal or exceed 1667 , as that is the HHI for six identically sized firms. Five hospitals offered invasive cardiology services in the El Paso market, implying an HHI of at least 2000. Seidenstein v. Nat'l Medical Enter., Inc., 769 F.2d 1100, 1106 (5th Cir. 1985) (monopolization claim). However, over 20 hospitals in the New Orleans area offer the anesthesiology services at issue in Jefferson Parish Hosp. Dist. v. Hyde, 466 U.S. 2, 7 (1984)

282. Over 20 diagnoses were studied, including obstetrics and surgical procedures for opthalmology, vascular/cardiac, hernia repair, orthopedic, plastic surgery, urological, nervous system, and procto-surgery.

283. Wilder \& Jacobs, Antitrust Considerations for Hospital Mergers: Market Definition and Market Concentration, 7 Advances in Health Econ. 245 (1987).

284. This study should be treated with caution, however. It is difficult to be confident that these statistics correctly represent the concentration ratios that will be found in markets for most hospital services. It is also uncertain whether these regions are representative of hospital concentration in most localities; whether the areas studied constitute geographic markets; and whether hospitals lack production flexibility among the various procedures (so that each diagnosis identifies a product market). See Frech, Comments on Antitrust Issues, 7 Advances in Health Econ. And Health Services RES. 263, 266 (1987).

285. Morissey, Sloan \& Valvona, supra note 246, at 186 . However, in three out of four SMSA's chosen for closer study, the HHI fell below 1800 if the geographic market was broadened beyond the metropolitan area. Id. The appropriate geographic market is discussed supra note 262. 


\section{Factors Facilitating or Frustrating Collusion}

In the DOJ Guidelines merger analysis, the inference about likelihood of collusion in the relevant market obtained from concentration statistics is adjusted based on an examination of entry conditions and other factors affecting the ability of the firms to collude. These factors may be sufficient to rebut the inference of anticompetitive effect created by a high degree of concentration. ${ }^{286}$

\section{Entry Conditions 287}

Along with the courts, ${ }^{288}$ the DOJ Guidelines recognize that no proposed market has antitrust significance if entry is easy. ${ }^{289}$ In a market without entry barriers, ${ }^{290}$ any price rise undertaken by a firm or group of firms would immediately be competed away by a new entrant into the industry. Even if limited entry difficulties exist, the threat of entry may nevertheless be

286. United States v. General Dynamics Corp., 415 U.S. 486, 498 (1974) (concentration creates a rebuttable presumption of anticompetitive effect).

287. The term "entry" in the DOJ Guidelines refers to one form of new competition that may discipline incumbent firms from exercising market power. Other forms of new competition are also recognized in antitrust analysis. Production flexibility (supply substitutabilty) is taken into account in market definition: The relevant market is broadened when production substitution is likely to occur within one year. 1984 Merger Guidelines, supra note 51, $\$ 2.21$. Production substitution requiring significant modification of existing facilities, so likely to occur within two years, is treated as entry along with the construction of new facilities. Id. $\$ 3.3$. The ability of incumbent firms to expand at low marginal cost is taken into account in defining market shares, see id. $\$ 2.4$, and for small incumbent firms is considered an independent factor frustrating collusion, id. $\$ 3.43$.

288. United States v. Waste Management, Inc., 743 F.2d 976 (2d Cir. 1984); Echlin Mfg. Co., 105 F.T.C. 410 (1985); United States v. Calmar, Inc., 612 F. Supp. 1298 (D.N.J. 1985).

289. 1984 Merger Guidelines, supra note 51, 3.3 . The Justice Department may require that potential defendants satisfy a higher evidentiary burden in demonstrating ease of entry than the courts require. Compare Rule, Merger Enforcement Policy: Protecting the Consumer (Remarks of Charles Rule Before the 1987 National Institute of the American Bar Association Section of Antitrust Law (October 9, 1987)), reprinted in 56 Antrrrus T L.J. 739, 745 (1988), with United States v. Waste Management, Inc., 743 F.2d 976 (2d Cir. 1984).

A market characterized by "ease of entry" in the antitrust literature is termed "contestable" in the economics literature. See generally W. Baumol, J. Panzar \& R. Willig, Contestable Markets and Industry Structure (1962); Baumol \& Willig, Contestability: Developments Since the Book, in STrategic Behaviour and Industrial Concentration (D. Morris, P. Sinclair, M. Slater \& J. Vickers eds. 1986). In such a market, even a single firm would be incapable of raising price to supracompetitive levels for an instant because that price increase would attract hit and run entry. An entrant would find it profitable to enter if prices were even slightly above competitive levels, and would compete just long enough to drive prices back down to their competitive level before exiting. For a market to be contestable, either entrants must bear no sunk costs (costs unrecoverable upon exit) or incumbent producers who are charging a supracompetitive price must be unable to increase output in response to entry for long enough to allow the entrant to recover its sunk costs through prices above entrant marginal cost. Farrell, How Effective is Potential Competition, 9 Econ. LetTers 67 (1986); Schwartz \& Reynolds, Contestable Markets: An Uprising in the Theory of Industry Structure: Comment, 73 AM. ECON. REV. 488 (1983); see Stiglitz, Technological Change, Sunk Costs, and Competition, 1987 Brookings PaPERS ON ECon. Activiry 883; see generally Spence, Contestable Markets and the Theory of Industry Structure: A Review Article, $21 \mathrm{~J}$. Econ. Literature 981 (1983).

290. Entry is relevant to merger analysis insofar as the prospect of new competition deters incumbent producers from anticompetitive actions. Thus, whether entry difficulties are classified as Stiglerian "barriers" or as "impediments" has little practical consequence for merger review. See Echlin, 105 F.T.C. at 485-87. In this article the term "entry barriers" encompasses both Stiglerian barriers and impediments. The Department of Justice similarly accepts a definition of entry barriers broader than Professor Stigler's. Rule, supra note 289, at 749-50. 
sufficient to create an effective deterrent to anticompetitive behavior. The DOJ Guidelines treat the possibility of entry as too remote to discipline the anticompetitive behavior of incumbent firms if entry will take more than two years. ${ }^{291}$

One entry barrier into providing medical services is created by the regulatory process. Certificate-of-need ("CON") legislation, intended to limit the tendency of hospitals serving insured patients to over-provide medical care, ${ }^{292}$ has an unintended by-product: it makes new competition more difficult. ${ }^{293}$ In states where they are required, CON proceedings impose both barriers to entry and impediments to expansion by incumbent producers. ${ }^{294}$ Under most state rules, de novo entry into the hospital industry or a major expansion by an incumbent competitor must be approved by the local CON board. Examples from the states show that this process can easily take at least two years, and thus create an entry barrier under the DOJ Guidelines definitions. ${ }^{295}$ The empirical economic evidence on the effect of CON laws is also consistent with the conclusion that they make entry difficult. ${ }^{296}$ This

291. The longer it will take before entry can compete away the exercise of market power, the more likely is an incumbent firm to exercise that power rather than be deterred from doing so. The DOJ Guidelines in effect presume that the prospect of entry within two years will deter the exercise of market power by incumbent firms. 1984 MERGER Guidelines, supra note 51, § 3.3. Although the period within which entry must occur to have this effect depends on a variety of factors including the potential gains from collusion, the real rate of interest, and the extent of entrant cost disadvantages, the two year horizon of the DOJ Guidelines appears to represent a reasonable rule of thumb.

292. See supra notes 16-17 and accompanying text.

293. Under the capture theory of regulation, this by-product is not unintended. Cf. Miller, Antitrust and Certificate of Need: Health Systems Agencies, the Planning Act, and Regulatory Capture, 68 GEo. L. REv. 873 (1980) (recommending statutory interpretation to limit possibility of capture).

294. See generally Hospital Corp. of Am., 106 F.T.C. 361, 489-96 (1985) (Georgia and Tennessee CON laws make speedy entry impossible), aff $d, 807 \mathrm{~F} .2 \mathrm{~d} 1381$ (7th Cir. 1986), cert. denied, 55 U.S.L.W. 3746 (1987); American Medical Int'l, Inc., 104 F.T.C. 1, 201 (1984) (California's CON procedure created "very high" barriers to entry).

295. The Federal Trade Commission found that the Tennessee CON process takes at minimum several months. If opposed by a competitor, as may often occur following a merger, the process may require several years even for a CON application that is ultimately approved. Administrative appeals and judicial review can add additional years to the process. Hospital Corp. of Am., 106 F.T.C. at 492. Similarly, in the late 1970's, once the state of Massachusetts began applying its CON laws in more than a pro forma manner, CON approval for major hospital bed projects took more than three years for a sample of hospitals. Howell, Evaluating the Impact of Certificate-Of-Need Regulation Using Measures of Ulimate Outcome: Some Cautions from the Experience in Massachuselts, 19 Health Services Res. 587, 607 (1984). Further, if state CON boards are "captured" by the incumbent hospitals, procompetitive entry and expansion could run a substantial risk of failing to obtain regulatory approval. See Miller, supra note 293, at 873; ff. American Medicorp, Inc. v. Humana, Inc., 445 F. Supp. 573, 602 n.9 (E.D. $\mathrm{Pa}$. 1977) (plaintiff claimed that a competing hospital acted to delay or prevent issuance of plaintiff's CON).

296. CON laws appear to raise both hospital prices and hospital expenses. M. NoETHER, supra note 25 , at $38,74,77$. This evidence suggests that entry barriers are raised, but that the hospitals studied dissipated their potential monopoly profits through expensive quality competition. Furthermore, using nationwide data from 1977 and 1978, Noether found that prices rose roughly over $4 \%$ on average in response to CON laws, just under the $5 \%$ level suggested as a deterrent to entry by the DOJ Guidelines. This average level is consistent with the view that CON laws form a high entry barrier in some states. Cf. Howell, supra note 295, at 587, 607 (differential enforcement of same laws over time in Massachusetts); see Hospital Corp. of Am., I06 F.T.C. at 494 (terming empirical 
barrier appears to be declining in significance over time, however, as states repeal their CON laws. ${ }^{297}$

Even absent CON requirements, entry into the hospital industry may be difficult. For many hospital services, the technological requirements of modern medical care demand buildings constructed or extensively remodeled to unusual specifications, including wide corridors and doorways, large elevators, strongly supported flooring, and extensive plumbing. In consequence, even without need for CON approval, once a decision is made to construct a new hospital building, planning may require two to six years, and construction may require an additional two to three years. ${ }^{298}$ Thus, de novo entry is unlikely to occur within the two years suggested by the DOJ Guidelines as an indicator of the significance of new entry. Moreover, a new hospital may be unable to achieve minimum efficient scale quickly, and thus may be unwilling to enter even if colluding hospitals raise prices above competitive levels. ${ }^{299}$

These entry difficulties are less important to the extent it is easy to create new institutions offering some medical services in competition with hospitals, such as free standing emergency centers and ambulatory care centers. ${ }^{300}$ Under such circumstances, the prospect of entry may significantly limit the possibility of anticompetitive conduct in the market for some medical services, while offering no restraint in other product markets.

In the current hospital environment, in which hospital occupancy rates have fallen dramatically in response to the introduction of reimbursement caps, ${ }^{301}$ excess capacity may strongly deter new hospital entry in many geographic markets even if incumbent hospitals raise price substantially. Excess capacity will deter entry if it suggests to prospective entrants that the marketplace will be very competitive following entry, with little profit opportunity. ${ }^{302}$

studies surveyed "ambiguous"). Evidence on the effect of CON laws in reducing health care costs is discussed supra note 22 .

Other evidence of the effect of CON laws in limiting new competition comes from the states where CON barriers were recently removed. "In at least two states, a surge in notices of intent to build [followed] . . . abolition of the entry program." M. NOETHER, supra note 25, at 37 .

297. See supra note 24 and accompanying text.

298. Howell, supra note 295 , at 587, 601 n.22.

299. See generally Salop, Measuring Ease of Entry, supra note 47. Government enforcers also consider scale economies an entry barrier into hospital markets. Winslow, supra note 103; Rule, supra note 115, at 128; see infra notes 346-47 and accompanying text (scale economies in the hospital industry).

300 . These institutions may need time to develop a reputation among patients (or doctors, acting as patient agents) for reliable health care, however, and thus may not be able to expand output quickly to compete away incumbent hospital market power. Further, they may not be able to achieve minimum efficient scale quickly, and thus may be unwilling to enter unless colluding hospitals raise price far above competitive levels. See generally Salop, Measuring Ease of Entry, supra note 47.

301. See supra note 28.

302. Any credible threat of post-entry competition can deter entry. Salop, Strategic Entry Deterrence, supra note 47.

Excess capacity is double-edged in antitrust analysis, however. Although it may deter new entry, it may also make collusion difficult by encouraging cheating on a cartel. See infra note 319 and accompanying text. 
In its recent hospital merger cases, the Federal Trade Commission readily found high entry barriers based on state certificate-of-need processes. ${ }^{303}$ It was not required to investigate whether barriers would have been high in the absence of certificates of need. ${ }^{304}$ Furthermore, because it defined product markets based on a cluster analysis, the Commission did not investigate the entry difficulties facing providers of some but not all services in the cluster. These issues will likely be contested in future hospital merger litigation as more states repeal certificate-of-need laws.

\section{Other Factors}

In evaluating the significance of concentration as a predictor of anticompetitive actions, the courts and the DOJ Guidelines take into account a variety of factors in addition to concentration and entry that affect the ease and profitability of collusion. ${ }^{305}$ Factors facilitating or frustrating collusion generally influence cartel decisions through one or more of three mechanisms. First, some factors alter the potential profits from collusion, by affecting cartel revenues or by affecting the costs of cooperative action. Second, some factors influence the ease of interfirm coordination, altering the ability of potential cartel members to agree on the cartel price and the allocation of cartel production among firms. Finally, some factors affect the ability of cartel members to police their arrangement by monitoring rival prices and outputs for compliance with the cartel agreement, and by punishing rival deviations from that agreement. The remainder of this section will discuss several such factors that might arise in antitrust litigation in the hospital industry, but will not attempt to create an exhaustive list. ${ }^{306}$

303. See supra note 295; accord Rockford, No. 88-C-20186, slip op. at 77-80 (N.D. Ill. Feb. 23, 1989), appeal filed.

304. Cf. Rockford, No. 88-C-20186, slip op. at 80 (N.D. Ill. Feb. 23, 1989) (a shrinking market would deter entrants from building new capacity even if CON regulation did not exist) (not analyzing whether this deterrent would be overcome if incumbent firms colluded to raise price), appeal filed; Carilion, 707 F. Supp. 840, 843-44, 845 (W.D. Va. 1989) (expansion of existing hospitals is not difficult because of current excess capacity and the likely removal of state limitations on hospital beds), appeal fled, No. 89-2625 (4th Cir. 1989).

305. 1984 Merger Guidelines, supra note 51, § 3.4 (1986); B.F. Goodrich Co., 1988 Trade Reg. Reports (CCH) I 22,519 (F.T.C. 1988); see generally F. SCHERER, INDUSTRIAL MARKET STRUCTURE AND Economic Performance 169-227 (2d ed. 1980) (cataloguing factors facilitating and limiting oligopolistic coordination); R. Clarke, Industrial Economics 56-63 (1985) (same); Horizontal MERGERS, supra note 35, at 171-72 (collecting cases), 201-263 (cataloguing factors); Salop, Practices that (Credibly) Facilitate Oligopolistic Co-Ordination, in New Developments in THE ANalysis of Market Structure (J. Stigliz \& G. Mathewson eds. 1986) (price protection provisions as facilitating practices).

306. Four structural factors facilitating or frustrating collusion that are not discussed in the remainder of this section will be briefly mentioned here. First, if seller cost functions differ substantially across firms, coordination of the colluding industry's output reduction may be difficult because simple rules (such as holding constant market share) may mean that some disfavored firms will gain little from the cooperative agreement. This factor might make it difficult for hospitals to collude with outpatient clinics. Hospitals may have high fixed costs and low marginal costs, while clinics may have low fixed costs but higher marginal costs for providing the same services. Under these circumstances, a perfectly coordinated cartel would obtain a higher price by reducing clinic output rather than hospital output, and the clinics would share in the anticompetitive gains through a 
a. Market demand elasticity. The incentives of firms to collude are small if the market demand curve is elastic because the potential monopoly profits are limited. Thus, hospitals are more likely to collude to raise the price of services patients are unable to do without and less likely to collude to raise the price of elective services. ${ }^{307}$

b. Service homogeneity or heterogeneity. Collusion is generally more difficult when sellers produce heterogeneous products than when they produce undifferentiated goods, because coordination becomes more complex and cheating is more difficult to police. ${ }^{308}$ In Hospital Corp. of America, the defendant hospitals unsuccessfully argued that the need for hospital administrators to coordinate prices across a large number of services made collusion unlikely, regardless of concentration. ${ }^{309}$ This argument is stronger when the product market is defined as a cluster of services, as it was in Hospital Corp. of America, than when individual services comprise relevant products. ${ }^{310}$ Furthermore, the prospective payment system in operation for Medicare provides hospitals with a well-defined classification of services over which to collude. In consequence, product heterogeneity will be unlikely to rescue defendant hospitals from the anticompetitive inferences created by high concentration.

side payment from hospitals. However, a tacit cartel may find it difficult to work out such a complex agreement.

Second, if transactions are open to the view of rival firms, collusion is more likely than if transactions are secret, because rivals cannot easily monitor secret purchases. This factor is no deterrent to hospital collusion. It would be prohibitively expensive for hospitals to undertake numerous secret negotiations with patients and hospital negotiations with government owned or regulated insurers cannot be kept from public knowledge.

Third, if hospitals in a region have a history of cooperation, future cartel coordination may be facilitated. Finally, frequent and substantial instability in market prices and market output may suggest that industry demand or supply is unstable. Collusion is less likely under this circumstance because frequent recoordination among cartel members may be necessary and cheating may be difficult to detect.

307. Cf. 1984 Merger Guidelines, supra note 51, $\$ 3.412$ (significance of degree of difference between the products and locations in the market and the next-best substitutes).

308. 1984 Merger Guidelines, supra note 5I, § 3.411. The DOJ Guidelines state that this factor will rarely be taken into account because heterogeneity is difficult to measure. In practice, the enforcement agencies appear to give this factor somewhat more weight than the DOJ Guidelines suggest. But of supra notes 133-35 and accompanying text (profitability of pairwise collusion increases with differentiation).

309. Hospital Corp. of Am., 106 F.T.C. 361, 506-508 (1985), aff d, 807 F.2d 1381 (7th Cir. 1986), cert. denied, 55 U.S.L.W. 3746 (1987).

310. Quality of care may differ across hospitals providing the same service, and thus form a basis for product differentiation among hospitals. See Hospitals, 6 Washington Consumers' Checkbook 13 (1987) (large quality differentials among hospitals in one metropolitan area). A cartel recognizing this must allow hospitals with a reputation for offering superior care to charge more for each service than is charged by other cartel members, by an amount reflecting the quality differential, in order to preserve identical prices in quality adjusted units. This will not unduly complicate the cartel coordination task when pre-cartel prices reflect the necessary differential.

A cartel among sellers offering products of differing quality must also police cheating on the collusive arrangement that takes the form of raising perceived service quality. See supra note 31 (quality competition). Although most ways of raising hospital service quality are time-consuming, involving improved facilities and staff, hospital cartels presumably must agree to limit advertising, as this activity could allow hospitals to increase consumer quality perceptions more rapidly. 
c. Role of nomprofits. Under some circumstances, the presence of nonprofit sellers in a market may make collusion unlikely. For example, if a seller cooperative maximizes sales rather than profits, it has no incentive to participate in a collusive agreement. ${ }^{311}$ Indeed, if it has excess capacity and the product is homogeneous, such a cooperative will likely undercut any cartel formed by its competitors. ${ }^{312}$ In practice, however, the nonprofit hospitals studied have behaved like for-profit hospitals. ${ }^{313}$ Hence, the presence of nonprofit hospitals in a market should rarely (if ever) mitigate an inference of market power obtained from market shares. ${ }^{314}$

d. Large buyers. Any seller wishing to cheat on a seller cartel can quickly and secretly achieve a large increase in output by contracting with a large buyer. As a result, the presence of large buyers can make a seller's cartel impossible to police. In addition, a large buyer may be more likely to recognize when sellers have colluded and act aggressively to encourage some sellers to cheat. $^{315}$

In Hospital Corp. of America, the Federal Trade Commission found that the presence of Blue Cross, a large buyer of hospital services in the Chattanooga market, did not materially affect the FTC's inferences of collusion derived from market shares. ${ }^{316}$ The FTC argued that Blue Cross had no particular ability to detect seller collusion relative to any other insurer, and, most tellingly, that the insurer had no ability to shift patients to non-colluding hospitals in the event a hospital wished to cheat on the seller's cartel. ${ }^{317}$ In other geographic markets, however, it is possible that a large HMO with the ability to shift a great number of patients away from a colluding hospital would be able to deter collusion among hospitals.

e. Excess capacity. Firms with excess capacity have strong incentives to compete away high prices, because they are able to increase output at low marginal cost. Hospital industry over capacity, presently common, ${ }^{318}$ may

311. Proving that the cooperative would sacrifice profits for sales may be difficult. At a minimum, it must be demonstrated that both the cooperative and its members would be incapable of withholding goods from the marketplace. This may be the case for cooperatives selling agricultural products likely to spoil.

Similarly, because public hospitals have missions of community service and charitable care, it is possible although unlikely that they will be managed in ways that limit their incentive to collude.

312. However, a multiproduct seller cooperative may have an incentive to raise price above marginal cost for inelastically demanded products in order to expand output of elastically demanded products through below-cost pricing of these goods. Lynk, supra note 156, at 68 .

313. Hospital Corp. of Am., 106 F.Г.C. at 502-04; Pauly, Nonprofit Firms in Medical Markets, 77 AM. ECON. Rev. 257 (Papers \& Proceedings 1987).

314. Rockford, No. 88-C-20186, slip op. at 84-93 (N.D. Ill. Feb. 23, 1989), appeal filed; but see Carilion, 707 F. Supp. 840, 849 (W.D. Va. 1989) (nonprofit hospital's board of directors, composed of business leaders, will ensure that cost savings are passed on to consumers), appeal filed, No. 89-2625 (4th Cir. 1989).

315. See Scheffman \& Spiller, Buyers and Entry Barriers, working paper no. 154 (F.T.C. Aug. 1987).

316. Hospital Corp. of Am., 106 F.T.C. at 508-10.

317. Cf. Staten, Dunkelberg \& Umbeck, Market Share and the Illusion of Power, 6J. HeALTH ECON. 43

(1987) (Blue Cross is unable to force hospitals to discount rates in Indiana).

318. See supra note 27. 
therefore operate to reduce the likelihood of collusion inferred from market concentration. ${ }^{319}$ Moreover, persistent excess capacity in a stagnant or declining market may make plausible a claim of financial weakness of the merging parties. ${ }^{320}$

f. Product complementarity. Although a theoretical case can be made for the effects of strong complementarity in frustrating some types of hospital collusion, in most cases these effects will not be large. Therefore, antitrust enforcers and courts should not give these effects much weight in the review of hospital mergers absent a careful cost or demand study quantifying them. A brief review of the relevant considerations relying on the earlier analysis of the role of complementarity in product market definition is set forth below.

If several goods or services are strong supply complements, firms will profit more by colluding over the provision of all than in the provision of just one. But if collusion is difficult or impossible in the market for some joint products, for example if another technology allows single product sellers to compete successfully in that market, then the multiproduct producer of supply complements likely has a reduced incentive to collude in the other joint products. This qualification is unlikely to be significant, however, unless the products are strong supply complements. Even if complementarity makes a cartel concerning some but not all joint products less profitable, it is unlikely to make collusion unprofitable. ${ }^{321}$ Thus, if a cartel can be expected to cover some but not all of the complementary goods or services, strong supply complementarity should be treated as a factor slightly reducing the incentive of firms to collude. In the hospital context, this issue may arise if outpatient clinics compete with hospitals in markets for some types of primary care, so long as inpatient hospital care has scope economies for the provision of those types of primary care. ${ }^{322}$

Strong complementarity in demand may complicate the coordination task of a cartel among the sellers of some but not all such goods because the single product sellers will desire a higher cartel price than the multiproduct sellers. ${ }^{323}$ This divergence of interest is the most difficult to reconcile when the goods are strong complements and when multiproduct producers have substantially more sales revenues coming from the complementary good than from the cartelized product. ${ }^{324}$ In such a case, demand complementarity would provide a strong force frustrating collusion. However, with the possible exception of simple surgery and inpatient care, health care services that are demand complements are typically performed by the identical firms,

319. However, excess capacity may also operate as an entry barrier, making collusion more likely. See supra note 302 and accompanying text.

320. See infra notes $348-54$ and accompanying text.

321. See supra notes $188-92$ and accompanying text.

322. But see supra note 175 (hospital scope economies may not exist).

323. See supra notes 193-200 and accompanying text.

324. This situation is the most likely to occur in the context of vertical integration. See supra note 195. 
namely hospitals. While demand complementarity may reduce a hospital's incentive to collude with outpatient surgical clinics over the price of simple surgical services, this force is unlikely to affect the hospital's incentive to collude with rival hospitals in other product markets. ${ }^{325}$

Finally, firms may need to collude over strong transactions complements in order to reduce the ability of rivals to cheat. ${ }^{326}$ If collusion concerns some but not all transactions complements, it may be frustrated. Although most hospital services may be transactions complements, it is difficult to gauge the strength of this complementarity. Furthermore, to the extent patient charges are quoted based on diagnostic categories, as under Medicare reimbursement schemes, ${ }^{327}$ hospitals have no opportunity to cheat on a cartel concerning one service, such as coronary bypass surgery, by lowering the price of another service such as the room charge. Nevertheless, it is possible that transactions complementarity may frustrate hospital collusion if the cartel is limited to a small group of services excluding some complements.

g. Opposition of competitors. It is sometimes suggested that when competitors of the merging firms oppose an acquisition, the transaction is likely to be procompetitive. According to this theory, firms can be expected to oppose acquisitions that lower their competitor's costs, and to favor mergers likely to lead to higher prices through facilitating industry collusion. Under this view, the fact of opposition by competitors should weigh against finding an antitrust violation. ${ }^{328}$ Indeed, this information has probative weight in the merger enforcement decisions of the Antitrust Division and the Federal Trade Commission. ${ }^{329}$

There are two problems associated with making these inferences. First, the raising rivals' costs literature demonstrates that some forms of anticompetitive conduct harm rivals. ${ }^{330}$ Because competitors may foresee private harm from anticompetitive mergers, as well as from procompetitive acquisitions, it is inappropriate to reason that an acquisition opposed by rivals necessarily creates efficiencies. More importantly, this theory invites a court or enforcement agency to avoid its responsibility to decide the case on the evidence because it substitutes a third party's judgment as to competitive consequences for the decisionmaker's own analysis. While the third party at issue, a competing seller, is familiar with the industry, a court likely has at least as much information about the relevant aspects of the industry and the transaction in question when the record is complete. Similarly, the

325. Presumably, the major restraint on collusion in the provision of simple surgery is ease of entry by new outpatient surgical clinics, and not this problem with demand complementarity.

326. See supra notes 201-04 and accompanying text.

327. See supra notes 19-24 and accompanying text.

328. Although not strictly speaking a factor facilitating collusion, this consideration is sometimes treated as a factor tending to weigh against the influence of anticompetitive harm raised by market concentration. Cf. infra note 339 (inferences from the support of customers).

329. This theory has also been influential in shaping the procedural requirement that a private plaintiff show antitrust injury.

330. See supra note 45. 
enforcement agencies likely know substantially more about both topics than do rivals after reviewing party responses to a request for additional information under the Hart-Scott-Rodino Act. For this reason, courts reviewing hospital mergers have found no probative value in the identity of third parties favoring or opposing the transaction. ${ }^{331}$

\section{Applying Facilitating Factors to Hospital Mergers}

In its Hospital Corp. of America decision the Federal Trade Commission recognized the influence of several factors facilitating or frustrating hospital collusion, including some not discussed above. The FTC concluded that the low elasticity of demand for hospital services raised the incentives of firms within the relevant market to collude, making collusion more likely. ${ }^{332}$ The Commission also noted that the inability of hospital patients to resell hospital services could help hospitals collude to raise prices for readily identifiable groups of consumers, such as the patients reimbursed by one insurance company. ${ }^{333}$ The Commission further relied upon hospital industry traditions of limited price competition and cooperative problem solving through voluntary health planning, as well as a past history of collusion and a pattern of information exchange among the hospitals at issue, as factors facilitating collusion. ${ }^{334}$

The FTC rejected defendant's arguments that a variety of structural factors which might frustrate hospital collusion were significant on the facts of the case. These included a history of hospital competition; service heterogeneity; the alleged likely procompetitive behavior of nonprofit hospitals; the instability of demand and supply; and the presence of a larger insurer as a major customer. ${ }^{335}$

\section{E. Defenses}

Two factors mitigating the possible competitive harm from an acquisition are treated as defenses: the creation of efficiencies, and the acquired firm's financial condition. ${ }^{336}$ Both defenses are strictly construed, and thus are rarely successful.

331. Hospital Corp. of Am., 807 F.2d at 1392 (competitor's opposition to acquisition is just one firm's opinion not shared by the court); Rockford, No. 88-C-20186, slip op. at 93-94 (N.D. Ill. Feb. 23, 1989) (rival may fear merged entity will act to raise rival's costs), appeal filed.

332. Hospital Corp. of Am., 106 F.T.C. 361,499 (1985), aff'd, 807 F.2d 1381 (7th Cir. 1986), cert. denied, 55 U.S.L.W. 3746 (1987).

333. Id. at 500. This factor reduces coordination difficulties for cartel members.

334. Id. at 500-01.

335. Id. at $501-11$.

336. Defendants have been unsuccessful in advancing the view that hospital acquisitions should be given more relaxed antitrust scrutiny than acquisitions in other industries because of the unique character and importance of health care. Id. at 512; cf. supra notes 71-73 and accompanying text (Congress did not impliedly repeal application of antitrust laws to health care). 


\section{Efficiency Defense}

Historically substantial efficiencies, such as a significant reduction in production costs, would not save an acquisition with potential for collusion. In three decisions in the 1960's, the Supreme Court refused to consider possible efficiencies as a defense, on the ground that Congress had proscribed increases in concentration regardless of whether consumers might benefit. ${ }^{337}$ In accordance with the modern emphasis on construing antitrust rules to promote economic efficiency, however, the DOJ Guidelines treat efficiencies as a relevant consideration in merger enforcement. ${ }^{338}$ The DOJ Guidelines recognize that efficiencies are often easy to allege and difficult to prove, and therefore require "clear and convincing evidence" as a predicate for considering them in deciding whether to challenge a merger. ${ }^{339}$ Similarly, the Federal Trade Commission recognizes economic efficiencies as a relevant factor in assessing the competitive impact of an acquisition, but requires that they be established by substantial evidence and insists that defendant demonstrate that the efficiencies could not be achieved within a comparable period of time through a merger that threatens less competitive harm. ${ }^{340}$ In addition, the antitrust enforcement agencies will seek to find ways of

337. FTC v. Procter \& Gamble Co., 386 U.S. 568, 580 (1967); United States v. Philadelphia Nat'l Bank, 374 U.S. 321,371 (1963); Brown Shoe v. United States, 370 U.S. 294, 344 (1962). These decisions attempted to harmonize political and social goals of antitrust law with economic efficiency goals. See supra notes 35-61 and accompanying text (changing goals). As the dominant view of the 1980's emphasizes economic efficiency to the exclusion of other goals, these decisions will likely be reconsidered by the Court in a future merger case along lines recently suggested by the FTC. American Medical Int'l, 104 F.T.C. 1, 215-20 (1984) (earlier Court statements are dicta; recent Court emphasis on economic evidence allows consideration of efficiencies); see Muris, The Efficiency Defense Under Section 7 of the Clayton Act, 30 CASE W. Res. L. REv. 381, 409-10 (1980) (Supreme Court has reserved the question of whether an efficiency gain in the same market as the merger could offset an anticompetitive outcome in that market). Cf. Broadcast Music, Inc. v. Columbia Broadcasting System, Inc., 441 U.S. 1 (1979) (production efficiency gain immunizes cooperative pricing policy from Sherman Act challenge despite per se prohibition of horizontal price fixing).

338. 1984 Merger Guidelines, supra note 51, § 3.5. However, "no court has yet found the anticompetitive effects of a merger to be outweighed by countervailing public interest factors." ABA Antitrust Section, Antitrust law Developments 166 n.146 (2d ed. 1982).

339. 1984 MERGER Guidelines, supra note $51, \S 3.5$.

Cognizable efficiencies include, but are not limited to, achieving economies of scale, better integration of production facilities, plant specialization, lower transportation costs, and similar efficiencies relating to specific manufacturing, servicing, or distribution operations of the merging firms. The Department may also consider claimed efficiencies resulting from reductions in general selling, administrative, or overhead expenses, or that otherwise do not relate to specific manufacturing, servicing, or distribution operations of the merging firms, although as a practical matter, these types of efficiencies may be difficult to demonstrate.

Id. But cf. Rule, supra note 115, at 128 (The DOJ may exercise discretion "not to sue in a case where the efficiency gains substantially outweigh the competitive harm.").

The enforcement agencies often consider support for an acquisition by customers of the merging firms (such as health insurers in the case of hospital mergers) as evidence that the transaction generates cost savings rather than market power. Winslow, supra note 103, at 4-5; Rule, supra note 115 , at 128-29. This argument is subject to similar criticisms as were raised in the discussion of the view that opposition by rivals implies that a transaction is socially beneficial. See supra notes 328-31 and accompanying text.

340. American Medical Int 'l, 104 F.T.C. at 218-20. 
structuring the transactions through curative divestitures to preserve efficiencies while removing likely anticompetitive concerns. ${ }^{341}$

In both of its recent hospital merger cases, the Federal Trade Commission held that defendants failed to establish substantial efficiencies on the facts. The merging hospitals in American Medical International presented a cost study, but the Commission found the savings to be minimal. ${ }^{342}$ The alleged efficiency benefits in Hospital Corp. of America were quickly dismissed because defendants made no attempt to quantify them. ${ }^{343}$ Similarly, a recent federal district court decision rejected allegations that a hospital merger would save $\$ 41$ million because the proposed savings were not established by clear and convincing evidence, the reorganization costs of achieving those savings were excluded from the calculation, and some of the proposed savings were achievable by the firms unilaterally, without merger. ${ }^{344}$ In contrast, another district court upheld a challenged hospital merger in part because of evidence that the acquisition would save $\$ 40$ million through "capital avoidance and other clinical and administrative efficiencies."345 Merging hospitals seeking to claim efficiencies must also overcome the economic literature questioning the extent of scale and scope economies resulting from merger. ${ }^{346}$

Government enforcers ignore efficiency claims arising from shared support services (such as laundry, data processing, or laboratory operations) or from lower capital costs on the view that these cost savings can be achieved through joint ventures short of merger. However, the government will

341. For a Department of Justice description of the "fix-it-first" policy, see Remarks Before the 1987 National Institute of the American Bar Association Section of Antitrust Law (Oct. 9, 1987), reprinted in Rule, supra note 289, at 745-46. An FTC description is found in Clark, Merger Investigations al the Federal Trade Commission: An Insider's View, 56 AnTITrust L.J. 765, 773-77 (1988).

342. The company alleged it would save at most $5.6 \%$ per year. Much of the estimated savings could not be defended, and even if significant cost savings would have occurred, they would not have been passed on to consumers through lower prices given the nature of industry regulation. American Medical Int'l, 104 F.T.C. at 219-20. The merging hospitals also alleged that the acquisition would improve quality of care, by permitting the acquirer to maintain one of its hospitals as a "first-rate hospital." The FTC cited with approval the conclusion of its Administrative Law Judge finding this claim implausible on the record evidence. Id. at 213-15. While an efficiency defense could in principle be based on increases in quality as well as on reductions in cost, plaintiffs are unlikely to be able to offer "clear and convincing evidence" that a merger will increase quality of care.

343. Hospital Corp. of Am., 106 F.T.C. 361, 512-13 (1985), aff'd, 807 F.2d 1381 (7th Cir. 1986), cert. denied, 55 U.S.L.W. 3746 (1987).

344. Rockford, No. 88-C-20186, slip op. at 96, 98-103 (N.D. Ill. Feb. 23, 1989), appeal fled.

345. Carilion, 707 F. Supp. 840, 845 (W.D. Va. Feb. 13, 1989), appeal fled, No. 89-2625 (4th Cir. 1989).

346. Lave \& Lave, Hospilal Cost Functions, 5 Am. Rev. Pub. Health 193 (1984) (scale economies absent); Eakin \& Kniesner, Estimating a Non-Minimum Cost Function for Hospitals, 54 S. Econ. J. 583, 593-96 (1988) (typical hospital has overall diseconomies of scale, although many exhibit overall economies of scale); F. Sloan \& B. Steinwald, Insurance, Regulation, and Hospital Costs 196 (1980) (evidence on scale economies ambiguous); $c f$. Grannemann, Brown, \& Pauly, Estimating Hospital Costs, 5 J. Health ECON. 107 (1986) (finding scale economies in emergency room care but not in other outpatient care); but see Vitaliano, On the Estimation of Hospital Cost Functions, $6 \mathrm{~J}$. HEaLTH ECon. 305 (1987) (scale economies present); Luft, Bunker \& Enthoven, Should Operations be Regionalized?, 301 NEw EnG. J. MED. 1364 (1979) (same); Carr \& Feldstein, The Relationship of Cost to Hospilal Size, 4 INQUIRY 45 (June 1967) (same); cf. supra note 35 (efficiencies arising from multihospital systems). Further, the limited literature on scope economies suggests they are not prevalent. See supra note 175 . 
investigate a claim that a merger will lower costs through improved use of fixed assets or the elimination of duplicative services. ${ }^{\mathbf{3 4 7}}$ Thus, in two recent cases the Department of Justice permitted hospital mergers to occur unchallenged in concentrated markets when efficiencies appeared likely to result and when excess capacity made eventual exit likely otherwise. ${ }^{348}$

\section{Failing Firm Defense}

An anticompetitive merger may be allowed if one of the firms is in poor financial condition in order to preserve the failing firm's assets as a competitive force and to limit the loss to company shareholders and to the communities in which the failing firm operates. ${ }^{349}$ To the extent competitive pressures lead hospitals to exit from the industry, this defense may become important in hospital merger cases. ${ }^{350}$

The failing firm defense is strictly construed to minimize the anticompetitive danger: The firm must be on the verge of insolvency, the acquiring company must be the least anticompetitive purchaser available, and the acquired firm must have made unsuccessful efforts to seek alternative buyers to preserve its assets in the marketplace while reducing the danger to competition. ${ }^{351}$ The Department of Justice has suggested that this defense might apply to permit the merger of the only two hospitals in a market that, as a result of the introduction of cost-based reimbursement, can only support one hospital. If, however, an outsider is willing to acquire the purportedly failing hospital at a price in excess of liquidation value, the outside purchaser will be preferred. ${ }^{352}$ The DOJ Guidelines allow a similar defense for a failing division which might apply to the sale of an unsuccessful hospital from an

347. Rule, supra note 115, at 128; Winslow, supra note 103. The Justice Department apparently presumes that scale economies are exhausted once a hospital reaches 300 to 600 beds, Rule, supra note 115 , at 128 , although it is willing to treat efficiency claims based on scale economies more generously in hospital merger cases than in most merger investigations for fear that competitive pressures will lead a failing hospital to provide inadequate care. Id. at 129 .

348. Rule, supra note 115 , at 129 . The influence of firm financial condition on merger analysis is taken up infra at notes $349-54$ and accompanying text.

349. United States v. General Dynamics Corp., 415 U.S. 486, 507 (1974); International Shoe Co. v. FTC, 280 U.S. 291,302 (1930)

350. See supra note 30 and accompanying text (exit statistics and competitive pressures); supra text accompanying note 320 (significance of excess capacity).

351. Citizens Publishing Co. v. United States, 394 U.S. 131, $137-38$ (1969); 1984 MERGER Guidelines, supra note $51, \S 5.1$. One district court rejected the application of the failing firm defense to a "failing market" where future consolidation was said to be likely to occur but the acquired firm was not presently unhealthy. Rockford, No. 88-C-20186, slip op. at 96-97 (N.D. Ill. Feb. 23, 1989), appeal fled.

An alternative purchaser is less likely to be available in declining or stagnant markets with persistent excess capacity than in growing markets, but even in the former case the assets may be preserved in the industry by a purchaser who obtains them for a low liquidation price. It is unclear whether the Justice Department requires that a seller actively pursue alternative purchases under such circumstances. Felt \& Brooks, Critique of Department of Justice Review of Mergers and Other Corporate Combinations, 21 J. Health and Hosp. L. 131,132 (1988).

352. Rule, supra note 115 , at 129. The Department of Justice has approved mergers when exit seems likely and efficiencies will arise. See supra note 348 and accompanying text. 
otherwise healthy chain. ${ }^{353}$ Even when the failing firm defense is unavailable, the enforcement agencies will discount the market shares of weakened competitors in inferring competitive effects from concentration statistics. ${ }^{354}$

V

\section{Conclusion}

Antitrust law applies to hospital mergers just as to any other industry. In the current environment created by changing regulatory mandates and the resulting growth of competitive pressures, such mergers are occurring with increasing frequency.

Antitrust enforcement agencies and the courts will likely give hospital acquisitions careful scrutiny because of several structural characteristics of the hospital industry. Most importantly, entry barriers are often high and market concentration within metropolitan areas is likely substantial for many individual hospital services. Under these circumstances, whether a merger is enjoined will most likely turn on the extent to which hospitals not presently offering procedures and services can quickly add them, and the distance patients will likely travel in response to a hospital price rise. If supply substitutability will expand the product markets for various concentrated hospitals services sufficiently, or if urban geographic markets are found to be significantly broader then metropolitan areas, then concentration may be reduced to less troublesome levels and hospital mergers may generally avoid antitrust challenge. In consequence, market definition is likely to remain an important battleground in hospital merger litigation under the antitrust laws.

353. 1984 Merger Gutdelines, supra note 51 , § 5.2; cf. FTC, Statement Concerning Horizontal Mergers $\S 5$ (June 14, 1982) (failing division arguments will be taken into account, but bear a high burden because of difficulties of proof).

354. 1984 Merger Guidelines, supra note $51, \S 3.22$. 